\author{
UNIVERSIDADE DE SÃO PAULO
}

ESCOLA DE ENGENHARIA DE LORENA

Larissa Graziele Rauber Duarte

Avaliação do emprego do café torrado como aromatizante na produção de cervejas

Lorena

2015 



\section{Avaliação do emprego do café torrado como aromatizante na produção de cervejas}

Dissertação de Mestrado apresentado ao Programa de Pós Graduação da Escola de Engenharia de Lorena, Universidade de São Paulo para a obtenção do título de Mestre em Ciências na área de Microbiologia Aplicada

Orientador: Prof. Dr. João Batista de Almeida e Silva

Edição reimpressa e corrigida

Lorena - SP

Setembro, 2015 
AUTORIZO A REPRODUÇÃO E DIVULGAÇÃO TOTAL OU PARCIAL DESTE TRABALHO, POR QUALQUER MEIO CONVENCIONAL OU ELETRÔNICO, PARA FINS DE ESTUDO E PESQUISA, DESDE QUE CITADA A FONTE

Ficha catalográfica elaborada pelo Sistema Automatizado da Escola de Engenharia de Lorena, com os dados fornecidos pelo(a) autor(a)

Duarte, Larissa Graziele Rauber

Avaliação do emprego do café torrado como

aromatizante na produção de cervejas / Larissa

Graziele Rauber Duarte; orientadora João Batista de

Almeida e Silva - ed. reimp., corr. - Lorena, 2015. $115 \mathrm{p}$.

Dissertação (Mestrado em Ciências - Programa de Pós Graduação em Biotecnologia Industrial na Área de Microbiologia Aplicada) - Escola de Engenharia de Lorena da Universidade de São Paulo. 2015

Orientadora: João Batista de Almeida e Silva

1. Aromatizante. 2. Café. 3. Cerveja. 4. Álcool. 5. Análise sensorial. I. Título. II. Silva, João Batista de Almeida e, orient. 
Aos meus pais Wilson e Gisela por sempre acreditarem em mim e me apoiarem nas minhas decisões, e aos meus irmãos e familiares pela amizade e pelo incentivo. 



\section{AGRADECIMENTOS}

Primeiramente aos meus pais Wilson e Gisela que sempre me incentivaram a estudar e a buscar os meus sonhos, pelo apoio incondicional, força e carinho.

Ao meu orientador Prof. Dr. João Batista de Almeida e Silva, pela oportunidade que me foi concedida de desenvolver esse trabalho e pela confiança em mim depositada.

Aos meus irmãos Gieser e Maxwel pela parceria e apoio.

As minhas tias, avós e primos gaúchos: Lidvina, Edmundo, Sueli, Irene Clair, Lurdes, Luis Henrique, Ana Cristina, Ana Carolina, Carine e Lis pelo carinho e incentivo.

À minha tia carioca Amelinha também pela hospedagem na sua casa quando eu fui ao Rio fazer as análises e pelo estímulo.

À Escola de Engenharia de Lorena e ao Programa de Pós-Graduação em Biotecnologia Industrial pela oportunidade de realização do mestrado.

À Coordenação de Aperfeiçoamento de Pessoal de Nível Superior (CAPES), pela concessão da bolsa de estudos.

Ao meu amigo que fiz aqui no laboratório, o Mestre Orerves pelos ensinamentos transmitidos e por sempre estar disposto a me ajudar quando eu tivesse alguma dúvida, e pela contribuição junto com o Valdir na execução do experimento na Planta Piloto.

Aos amigos da cervejaria: Valdir, Orerves, Diogo, Raquel Aizemberg, Raquel Almeida, Bárbara, Eduardo, Ricardo, Bruno, Matheus, Rafaela, Carolina, Afranio e Yanet pela convivência ao longo dessa caminhada, amizade e a troca de conhecimentos.

Aos amigos do Debiq e do Deq: Renata, Ludmila, Mayara, Sara, Milena, Ana Carine, Annie, Omar, Andrés, Zé Cobrinha, Jéssica, Cláudia, Lucas Ramos, André da secretaria e Joel da biblioteca pela ajuda, pelo café, pelas risadas, pelas festas e acima de tudo pelo apoio.

Aos professores do Debiq: Dra. Maria Bernadete, Dra. Maria das Graças, Dr. Ismael, Dr. Arnaldo, Dra. Adriane, Dr.Walter pelos ensinamentos.

Á Malteria do Vale pela doação de maltes.

Ao Professor Dr. Thiago Rocha dos Santos Mathias, do Instituto Federal de Educação, Ciência e Tecnologia do Rio de Janeiro, pela ajuda na execução das análises das minhas amostras de cerveja feitas em escala piloto.

Enfim, a todas as pessoas que contribuíram direta ou indiretamente para a realização e conclusão desse trabalho. 

"Não se contente em trilhar um caminho estabelecido. Ao contrário vá para onde não há caminho algum e deixe seu rastro." 



\section{RESUMO}

DUARTE, L. G. R. Avaliação do emprego do café torrado como aromatizante na produção de cervejas. 2015. 115 p. Dissertação (Mestrado em Ciências) - Escola de Engenharia de Lorena, Universidade de São Paulo, 2015.

O principal objetivo desse trabalho foi contribuir para o desenvolvimento de uma tecnologia de produção de cerveja empregando café como aromatizante. Primeiro foi avaliado se o café poderia ser usado como adjunto, para isso foram feitas análises em Cromatografia Líquida de Alta Eficiência (HPLC), para avaliar os açúcares presentes em um mosto de cerveja usando como adjunto café. Devido a baixa contribuição de extratos fermentescíveis oriundos do café, resolveu-se que o café não poderia ser usado como adjunto e sim como aromatizante. Realizou-se uma análise sensorial usando a escala do ideal para avaliar a intensidade de café na cerveja considerado ideal pelo consumidor. A amostra utilizada durante o teste foi uma cerveja usando $45 \%$ de café como adjunto. $57 \%$ dos julgadores consideraram o sabor de café muito mais intenso que o ideal, portanto a cerveja com $45 \%$ de café foi reformulada com diferentes concentrações de café, $45 \%$, $35 \%, 25 \%, 15 \%$ e $0 \%$ usando como aromatizante na etapa da fervura. O teor alcóolico das cervejas produzidas se apresentou entre 5,17 a $5,78 \%(\mathrm{v} / \mathrm{v})$ o que as caracterizaram como cervejas de alto teor alcoólico. Foram realizadas análises microbiológicas, a cada 12 horas, contagens em câmara de Neubauer e expresso em número de células/mL. Após o final da fermentação foram calculados o rendimento, produtividade em álcool e a eficiência do processo, encontrando valores que variaram entre $0,49 \mathrm{~g} / \mathrm{g}$ e $0,50 \mathrm{~g} / \mathrm{g}$; 0,57g/L.h e 0,63g/L.h e 93,8\% e 97,8\%, respectivamente. A primeira análise sensorial demonstrou que a cerveja aromatizada com $45 \%$ de café foi a mais bem avaliada em todos os quesitos. Analisando os hábitos dos consumidores de cervejas, observou-se um aumento pela procura por cervejas diferenciadas e com mais sabor e uma possível grande aceitação no mercado de cervejas aromatizadas com café. A segunda análise sensorial, comparando a cerveja produzida em escala piloto aromatizada com 45\% de café com uma comercial, apresentou ótimas notas para todos os atributos e para a intenção de compra.

Palavras-chave: Aromatizante. Café. Cerveja. Álcool. Análise Sensorial. 


\section{ABSTRACT}

DUARTE, L. G. R. Evaluation of roasted job as a flavoring in the production of beers. 2015. 115 p. Dissertation (Master Of Science) - Escola de Engenharia de Lorena, Universidade de São Paulo, 2015.

The main objective of this study was to contribute to the development of beer production technology using coffee as a flavoring. First it was evaluated whether the coffee could be used as an adjunct, these analysis were made in High Performance Liquid Chromatography (HPLC) to evaluate the sugars present in a beer wort using coffee as deputy. Due to the low contribution of fermentable extracts derived from the coffee, it was resolved that coffee could not be used as an adjunct but as flavoring. We conducted a sensory evaluation using the scale to evaluate the ideal coffee considered ideal intensity in beer by the consumer. The sample used for the test was a beer using $45 \%$ of coffee as an adjunct. $57 \%$ of the judges considered the much more intense coffee flavor than ideal, so the beer with $45 \%$ of coffee was reformulated with different coffee concentrations $(45 \%, 35 \%, 25 \%, 15 \%$ and $0 \%)$ and used coffee as a flavoring in the boiling step. The alcohol content of the beers performed between 5,17 to $5,78 \%$ (v/v) what was characterized as high-alcohol beers. Microbiological analyzes were performed every 12 hours, counts in Neubauer chamber and expressed in number of cells $/ \mathrm{ml}$. After the end of fermentation were calculated yield, alcohol productivity and efficiency of the process by finding values ranging from $0,49 \mathrm{~g} / \mathrm{g} 0.50 \mathrm{~g} / \mathrm{g} ; 0.57 \mathrm{~g} / \mathrm{Lh}$ and $0,63 \mathrm{~g} / \mathrm{Lh}$ and $93,8 \%$ and $97,8 \%$, respectively. The first sensory analysis showed that the flavored beer with $45 \%$ of coffee was the best evaluated in all aspects and purchase intent. Analyzing consumer habits of beers, there was an increase in the demand for differentiated and beers with more flavor and a possible wide acceptance in the flavored with coffee beer market. The second sensory analysis comparing beer produced in pilot scale flavored with $45 \%$ of coffee with a trade made perfect scores for all attributes and purchase intent.

Keywords: Flavoring. Coffee. Beer. Alcohol. Sensory Analysis. 


\section{SUMÁRIO}

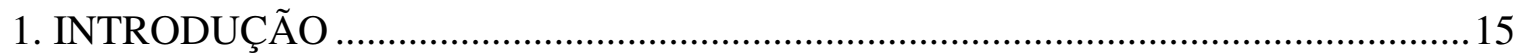

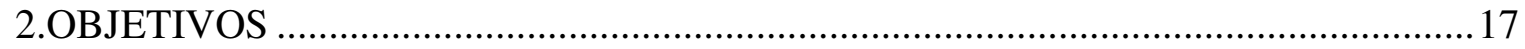

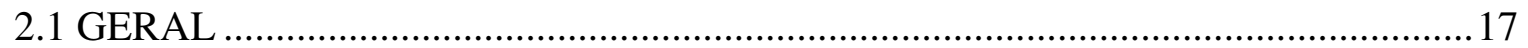

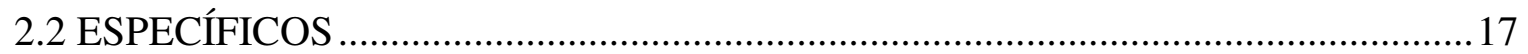

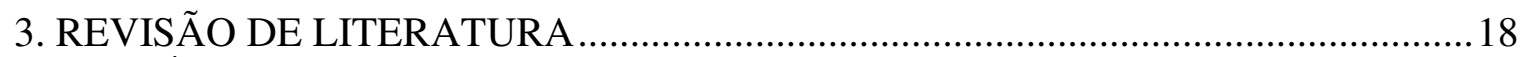

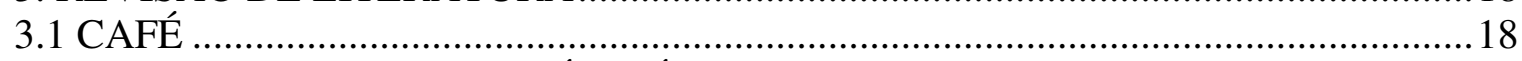

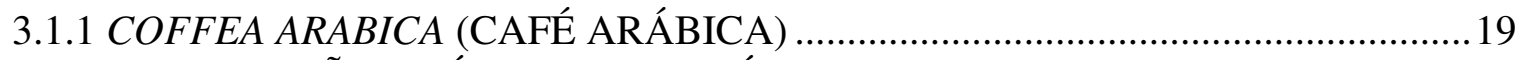

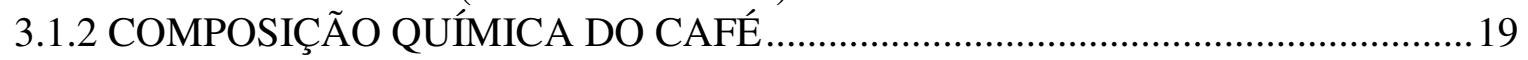

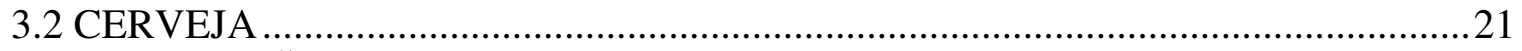

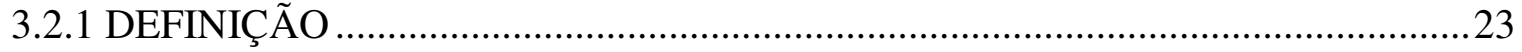

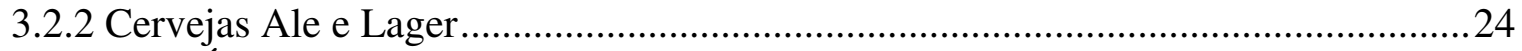

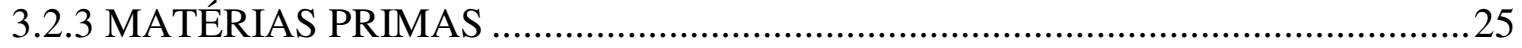

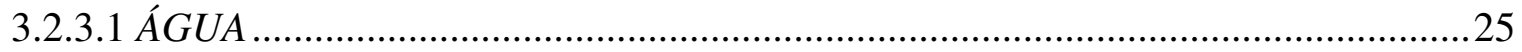

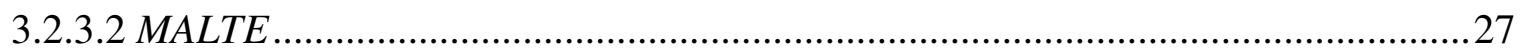

3.2.3.3 LÚPULO

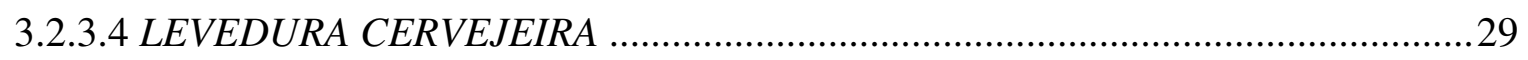

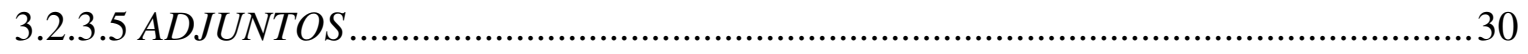

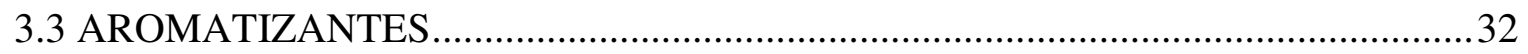

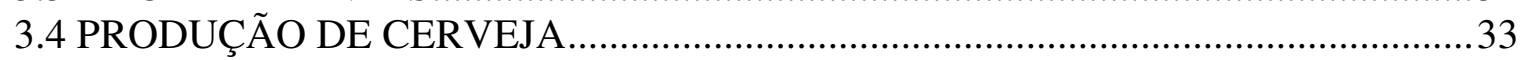

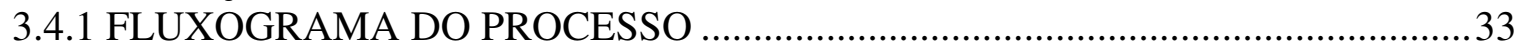

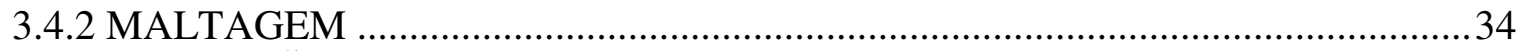

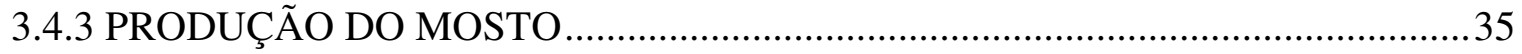

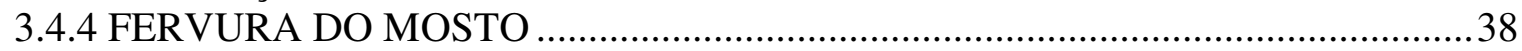

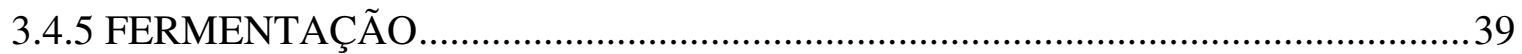

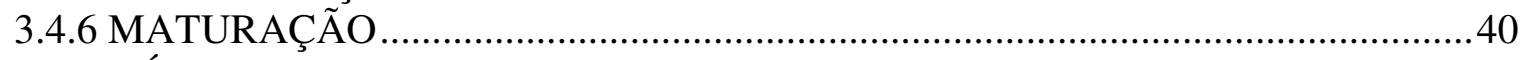

3.5 ANÁLISE SENSORIAL …………………………..................................

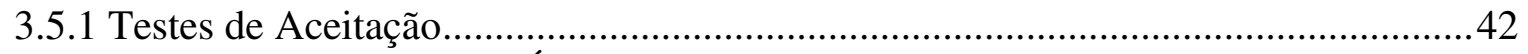

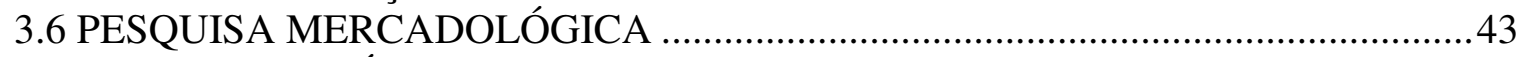

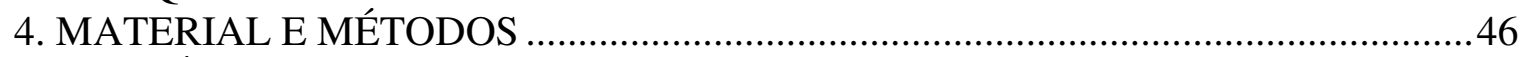

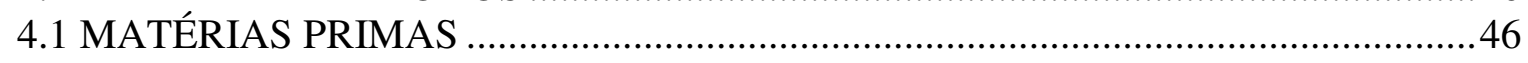

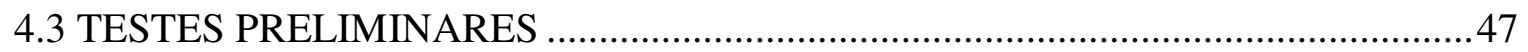

4.3.1 Elaboração dos mostos.......................................................................................4

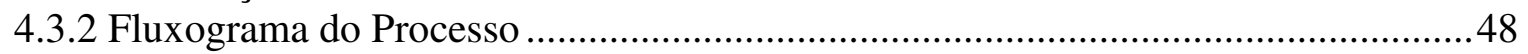

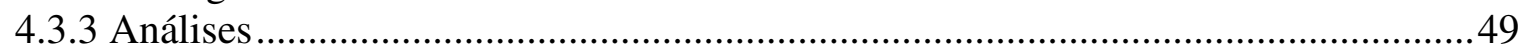

4.3.4 Análise Sensorial usando a escala do Ideal..............................................................49

4.5 PRODUÇÃO DE CERVEJA EM ESCALA LABORATORIAL …………………........50

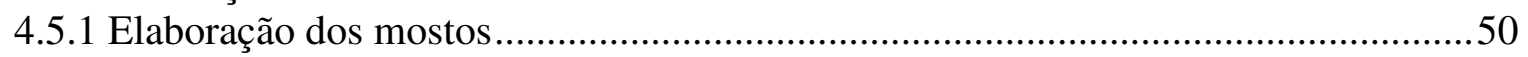

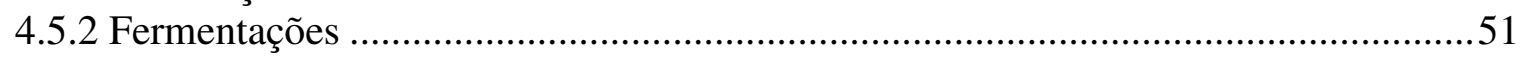

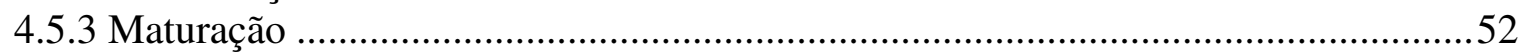

4.5.4 Carbonatação e Envase ……………………………………………………..52

4.5.5 Fluxograma do processo em escala laboratorial ………………..............................52

4.6 PRODUÇÃO DE CERVEJA EM ESCALA PILOTO ………………………............53

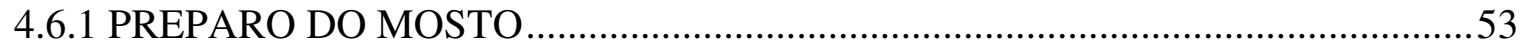

4.6.2 FILTRAÇÃO DO MOSTO ……………………………...................................5

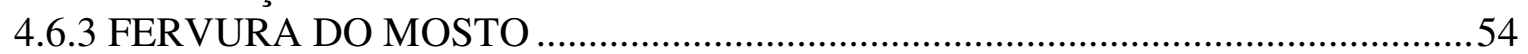

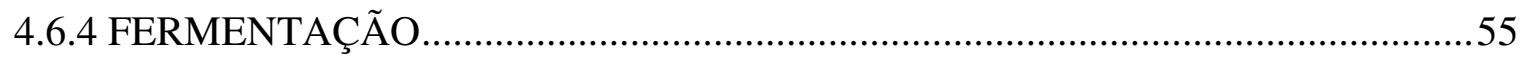




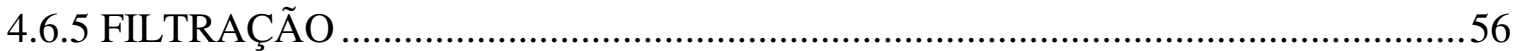

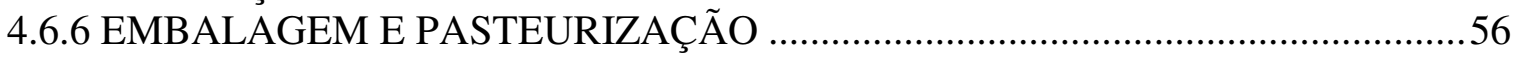

4.6.7 FLUXOGRAMA DO PROCESSO EM ESCALA PILOTO ...................................56

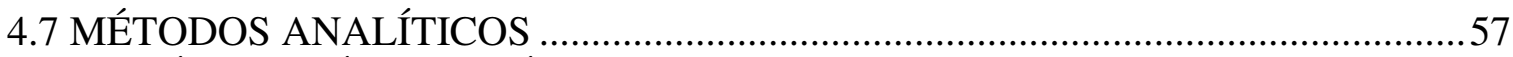

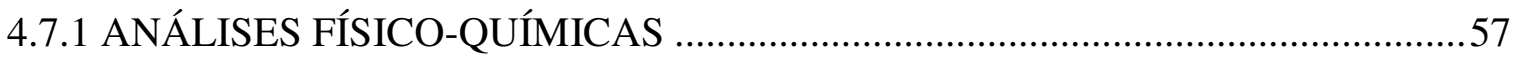

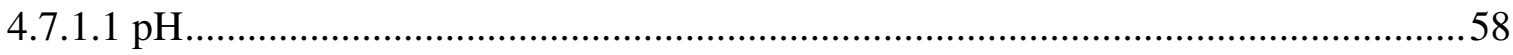

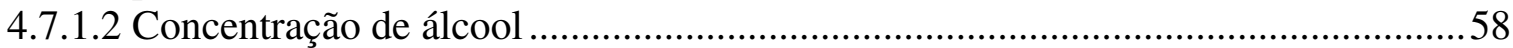

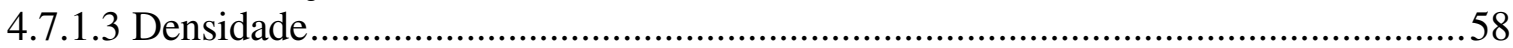

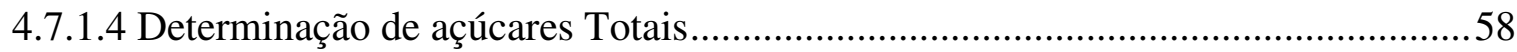

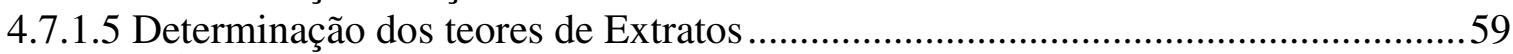

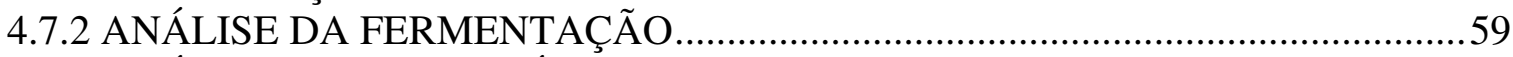

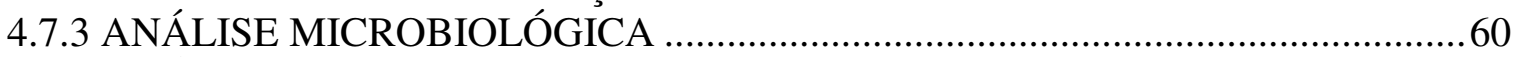

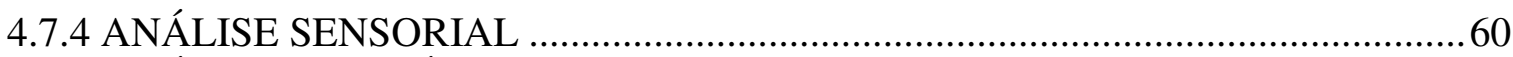

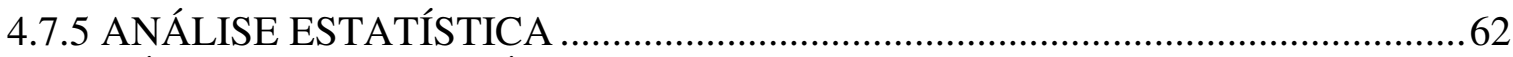

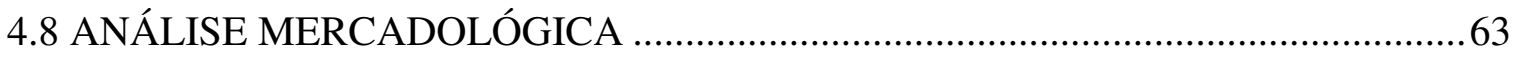

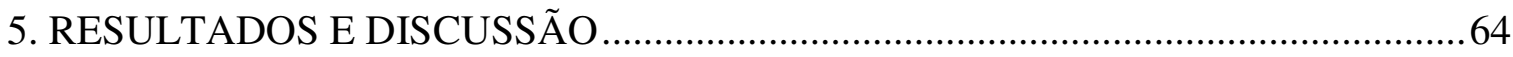

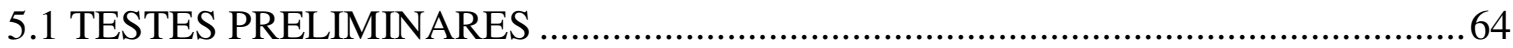

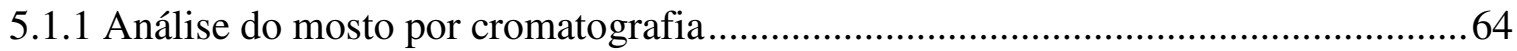

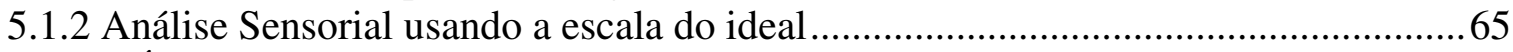

5.2 ANÁLISES DE pH DOS MOSTOS DAS CERVEJAS .............................................66

5.3ANÁLISES FISICO-QUIMICAS DAS CERVEJAS EM ESCALA

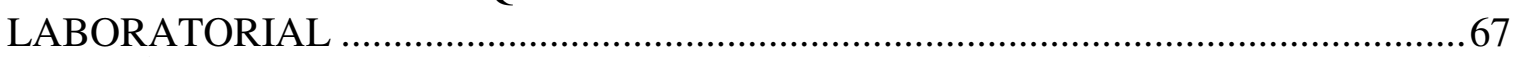

5.4 ANÁLISE SENSORIAL DAS CERVEJAS EM ESCALA LABORATORIAL ..........74

5.5 ANÁLISES FISICO-QUIMICAS DAS CERVEJAS EM ESCALA PILOTO ............81

5.6 ANÁLISE DOS HÁBITOS DOS CONSUMIDORES DE CERVEJA........................84

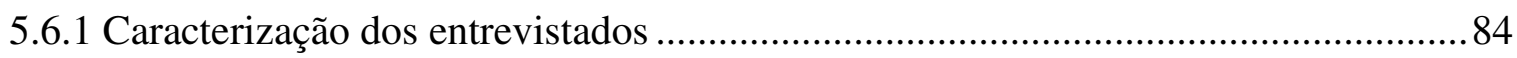

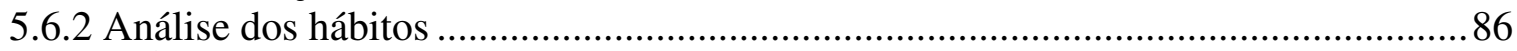

5.7 ANÁLISE SENSORIAL DAS CERVEJAS PRODUZIDAS EM ESCALA PILOTO

91

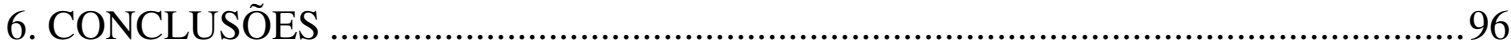

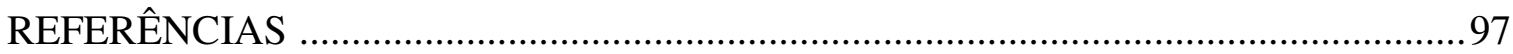

Apêndice A - Questionário aplicado para a pesquisa mercadológica ............................ 104

Apêndice B - Gráficos de Fermentação ...................................................................... 106 


\section{INTRODUÇÃO}

Na última década, a produção de cerveja no Brasil cresceu 64\%, de 8,2 bilhões para 13,4 bilhões de litros anuais, segundo dados do Sicobe (Sistema de Controle de Produção de Bebidas da Receita Federal). O Brasil é o terceiro maior produtor do mundo, atrás de Estados Unidos e China. Paralelamente a esse crescimento, o mercado nacional de cervejas premium ou especiais está sendo um dos mais promissores atualmente e está movimentando cerca de 300 milhões anualmente, correspondendo a 5\% do mercado total de cervejas.

A cerveja, por definição é uma bebida carbonatada de baixo teor alcoólico. Por regulamentação, a cerveja é produzida a partir de água, malte de cevada, levedura e lúpulo, podendo ser utilizadas outras fontes de carboidratos denominados adjuntos (SILVA, 2005).

A legislação brasileira permite que parte da cevada malteada possa ser substituída por adjuntos que podem ser cereais maltados ou não, carboidratos de origem vegetal transformados ou não. Estes adjuntos contribuem como fonte alternativa de substrato, com custos geralmente inferiores ao da cevada malteada e adicionalmente, proporcionam à bebida características sensoriais peculiares em função da fonte que provém (VENTURINI FILHO, 2010).

A elaboração de cervejas utilizando outros adjuntos denominados de não convencionais, como arroz preto, banana, pupunha, caldo de cana e pinhão vem se tornando uma solução de barateamento e proporcionando a bebida atributos sensoriais característicos (DRAGONE e ALMEIDA e SILVA, 2010). Existem em escala mundial inúmeros tipos de cervejas que se distiguem pelos diferentes ingredientes, métodos de elaboração e características sensoriais. Deste modo nota-se a necessidade de obtenção de cervejas com novos e variados aromas que atenda diferentes grupos de pessoas (CARVALHO, 2009).

Existem dois tipos de leveduras que são utilizadas no processo cervejeiro, Saccharomyces carlsbergensis e Saccharomyces cerevisiae, as quais conferem o tipo de fermentação empregado. Utilizando leveduras do tipo Saccharomyces carlsbergensis obtêm-se uma cerveja de baixa fermentação conhecida como lager, as quais decantam durante a formação de álcool, ao passo que na produção de uma cerveja de alta fermentação tipo ale usa-se leveduras do tipo Saccharomyces cerevisiae, estas por sua vez 
ficam suspensas no final do processo (ALMEIDA, 2011). Atualmente, como resultado de uma classificação recente das Saccharomyces, todas as cepas empregadas na produção de cerveja são denominadas Saccharomyces cerevisiae.

O presente trabalho, o qual propõe o desenvolvimento de um novo produto como uma cerveja com café elaborada com a fermentação do tipo ale, contribuirá para uma nova utilização do café, e permitirá através da análise sensorial, determinar qual cerveja será a mais aceita pelos consumidores. Assim, os produtores de café terão uma alternativa a mais para a utilização de sua safra, agregando maior valor a matéria prima produzida e incorporando no mercado diferentes tipos de cervejas. 


\section{OBJETIVOS:}

\subsection{GERAL:}

Contribuir para o desenvolvimento de uma tecnologia de produção de cerveja empregando café (Coffea arabica) como aromatizante.

\subsection{ESPECÍFICOS:}

- Avaliar a utilização de café torrado, como aromatizante na elaboração de cervejas;

- Produzir cervejas tipo ale;

- Determinar os parâmetros cinéticos do processo;

- Avaliar as características físico-químicas e sensoriais das bebidas;

- Fazer uma análise mercadológica 


\section{REVISÃO DE LITERATURA}

\subsection{CAFÉ}

A planta de café é originária da Etiópia, centro da África, onde ainda hoje faz parte da vegetação natural. Foi a Arábia a responsável pela propagação da cultura do café (ABIC, 2014).

A divulgação do café na Europa ocorreu em 1592 através do alemão Leonardo Rauwoff. Os holandeses foram cruciais na propagação do consumo do café como bebida por toda a Europa (BRAGANÇA, 2008).Enquanto no Brasil, o café foi introduzido em 1727 por Francisco Mello Palheta sendo que as primeiras sementes e mudas foram plantadas em Belém e em seguida no Maranhão (ABIC, 2014).

Atualmente o Brasil é o maior produtor mundial de café, sendo responsável por $30 \%$ do mercado internacional e é também o segundo mercado consumidor, ficando atrás somente dos Estados Unidos (ABIC, 2014).

A produção de café arábica se concentra em São Paulo, Minas Gerais, Paraná, Bahia e parte do Espírito Santo, enquanto o café robusta é plantado principalmente no Espírito Santo e Rondônia (ABIC, 2014).

O café pertence à família Rubiciae, gênero Coffea, sendo as espécies Coffea arabica e Coffea conephora, as principais variedades cultivadas no Brasil. As cultivares do café arábica estão associadas a bebidas de melhor qualidade porque possuem atributos sensoriais mais equilibrados após a torrefação. O café conilon é usado em "blends" (misturas de café) para melhorar o "corpo" da bebida final e para reduzir os custos (CAMPANHA; DIAS; BENASSI; 2010; FLAMENT, 2002)

Uma característica interessante da bebida café é o fato de não possuir valor nutricional relevante, sendo consumida principalmente pelo prazer e satisfação que seu aroma e sabor são capazes de proporcionar (SIVETZ; FOOTE, 1997).

O sabor e o aroma da bebida café são complexos, resultantes da presença combinada de constituintes químicos voláteis e não voláteis, entre eles os ácidos, aldeídos, cetonas, açúcares, proteínas, aminoácidos, ácidos graxos, compostos fenólicos, e também a ação de enzimas em alguns destes constituintes, dando produtos de reações, compostos que interferirão no sabor da bebida. Dentre estes compostos, 29 já foram 
identificados como os principais responsáveis pelo aroma característico do café torrado e moído (SARRAZIN et al., 2000).

A torrefação é uma das etapas mais importantes para o desenvolvimento do sabor e aroma do café. Nessa fase, os grãos sofrem algumas reações químicas importantes, necessárias à formação da qualidade sensorial (LOPES, 2000). A qualidade da bebida é influenciada diretamente pelo grau de torra. Em temperaturas acima de $140{ }^{\circ} \mathrm{C}$ é alcançada a formação total do aroma, temperaturas mais altas provocam a perda de aromas e gostos. Quanto mais alta a temperatura final da torrefação, menos desejável será o aroma e mais forte o amargor. Da mesma forma, temperaturas de torrefação baixas não desenvolvem inteiramente aromas desejáveis (ILLY, 2002).

O escurecimento dos grãos é devido em grande parte às reações de Maillard: reações químicas entre o açúcar redutor (principalmente a D- Glicose), e um grupo amina primário ( um aminoácido livre ou grupo aminoacídico da cadeia lateral de uma molécula de proteína). Esta reação também é chamada de escurecimento não enzimático (DAMODARAN; PARKIN; FENNEMA, 2010).

\subsubsection{COFFEA ARABICA (CAFÉ ARÁBICA)}

É uma planta mais delicada, que se desenvolve em altas altitudes, que geralmente é plantada entre os trópicos (ROSSETTI, 2007).

A espécie Coffea arabica se apresenta como a mais importante economicamente representando cerca de $75 \%$ da produção mundial (ICO, 2011), isto se deve às características da bebida proveniente dessas sementes, que apresentam qualidade superior.

\subsubsection{COMPOSIÇÃO QUÍMICA DO CAFÉ}

A composição quimica do café tem relação direta com a qualidade do café e depende da espécie, além de fatores como práticas agrícolas, grau de maturação do fruto do café e condições de estocagem (BANDEIRA, 2010). 
A torrefação altera a composição do grão por causa da desidratação, da oxidação e da carbonatação. Diminue os teores de água, açúcares, cafeína e taninos, e aumenta a quantidade de albuminas, extrativos não nitrogenados, celulose e cinzas (LIMA, 2010).

$\mathrm{Na}$ etapa de torrefação são formados os compostos que dão o sabor e aromas característicos à bebida de café (MORAIS et al, 2009; NASCIMENTO et al,2007).

A composição da infusão de café varia em conformidade com a quantidade de pó e da quantidade de água usada na sua preparação, da diluição dos componentes extraídos do pó de café encontrados no extrato.Varia também com a espécie de café e com a granulomentria do pó (LIMA, 2010).

O grão de café verde possui uma grande variedade de substâncias, por exemplo, minerais, aminoácidos, lipídeos, açúcares, ácidos clorogênicos e cafeína. Durante o processo de torrefação ocorre a formação e a degradação de várias substâncias. Algumas substâncias são preservadas nesse processo, como a cafeína que apresenta grande estabilidade à torrefação (ABRAHÃO et al, 2010).

A cafeína é o principal alcalóide presente nos grãos de café, em teor variável de 0,9 a 2,0\%; os cafés arábica geralmente encerram $1 \%$ e os da espécie robusta $2 \%$. É uma substância branca, cristalina, amarga, sem aroma, de solubilidade variável em água (LIMA, 2010).

O calor faz desenvolver o aroma e o sabor característicos. Reações de Maillard e caramelização são responsáveis pela cor, variável com a intensidade do aquecimento. Os grãos perdem umidade; a sacarose (7\% no grão verde) decresce; o $\mathrm{pH}$ passa de níveis de 6,0 a 5,1, formam-se ácidos voláteis (fórmico e acético) e furfural das pentosanas e o amido dextriniza (o amido é hidrolisado em aquecimento prolongado, há rompimento das membranas liberando dextrina), enquanto a celulose, hemicelulose e lignina não são muito afetadas pela pirólise (LIMA, 2010). 
Tabela 1- Composição química do café verde e torrado.

\begin{tabular}{lcc}
\hline \multicolumn{1}{c}{ Componentes } & \multicolumn{2}{c}{ \% sobre a matéria úmida } \\
\cline { 2 - 3 } & Grãos verdes & Grãos torrados \\
Albuminas & 11,89 & 13,77 \\
Cafeína & 1,29 & 1,27 \\
Matéria graxa e extrato & 12,34 & 13,02 \\
etéreo & & \\
Açúcares & 8,39 & 1,23 \\
Ácido tânico & 6,42 & 4,69 \\
Extrativos não & 18,11 & 32,39 \\
nitrogenados & & \\
Celulose & 26,16 & 26,31 \\
Cinzas & 4,04 & 4,69 \\
Ácidos clorogênicos totais & $5,5-8,0$ & $1,2-2,3$ \\
\hline
\end{tabular}
Fonte: NOSTI NAVA, 1953 e adaptado de CLARKE e MACRAE, 2003.

\subsection{CERVEJA}

A cerveja é provavelmente originária do Oriente Médio ou do Egito. Há cerca de 5 mil anos já existia a bebida, fabricada a partir de água e malte pelos sumérios na Mesopotâmia. Existem registros na China também, de 4 mil anos da Kiu (cerveja à base de cevada, trigo, milho e arroz) (OETTERER, 2006).

Antes do surgimento da escrita, encontra-se registros tanto em linguagem cuneiforme quanto em hieróglifos. Os registros existentes são desenhos rupestres, símbolos primitivos que representam a fabricação da cerveja (MORADO, 2009).

Há alguns anos atrás, foi encontrada uma receita de cerveja extraída de murais de túmulos egípcios datados de 2650 e 2180 a. C. Os egípcios fizeram com que a cerveja ficasse conhecida pelos outros povos orientais, chegando à Europa e depois para o resto do mundo (SILVA, 2005).

Os egípcios faziam vários tipos de cervejas sob o nome genérico de zythum. As mais suaves eram destinadas aos pobres e as aromatizadas eram reservadas aos nobres. Essa bebida era indispensável nas cerimônias fúnebres e era usada também em banhos, como tratamento da pele (MORADO, 2009).

A cerveja era preparada com uma mistura de água, pão semi-cozido, malte de cevada e suco de tâmaras ou tamarindos. Depois era fermentada em recipientes de madeira acácia (TSCHOPE, 2001). 
$\mathrm{Na}$ Antigüidade, usava-se na produção da cerveja, toda espécie de ingredientes como: folhas de pinheiro, ervas em geral, cerejas silvestres, entre outros. O uso desses ingredientes, alguns desconhecidos, era fatal em algumas ocasiões (TSCHOPE, 2001).

O primeiro regulamento sobre o processo de fabricação de cervejas ocorreu na Baviera em 1516. A "Lei de Pureza" alemã determinava que os ingredientes para a fabricação da bebida seria cevada malteada, lúpulo e água (OETTERER, 2006). Essa lei decretou que somente o lúpulo podia ser utilizado para conferir sabor amargo à cerveja produzida na Alemanha (SILVA, 2005).

Na Idade Média, os cervejeiros da Germânia foram os primeiros a empregar lúpulo na cerveja (AQUARONE, 2001). Apesar do seu amargor, o lúpulo foi adotado devido as suas propriedades de conservação (MORADO, 2009).

Em 1808, D. João disseminou o hábito de tomar cerveja durante a permanência da família real portuguesa no Brasil. A cerveja era importada de países europeus. Em 1888 a cerveja começou a ser produzida no Brasil com a fundação da "Manufatura de Cerveja Brahma Villigier e Cia” no Rio de Janeiro e em 1891 da Companhia Antartica Paulista em São Paulo. Depois as empresas se fundiram originando a Ambev (AQUARONE, 2001).

Com o início do século XX houve o surgimento de muitas microcervejarias, com a nascente sociedade burguesa, o início da industrialização e a chegada de um grande número de imigrantes europeus (MORADO, 2009).

A disputa pelo mercado brasileiro atualmente se faz em duas frentes: a do tradicional produto de mercado (cervejas de grandes indústrias), e a das cervejas especiais, com maior valor agregado (cervejas de microcervejarias) (MORADO, 2009).

A cerveja de microcervejaria caracteriza-se pela elaboração de uma bebida mais encorpada, com aroma e sabor mais pronunciados. Um dos fatores que explicam esta diferença entre a cerveja elaborada por microcervejarias e grandes cervejarias é a utilização de variedades específicas de lúpulo, que justificam o crescimento acentuado deste segmento (Keukeleire, 2000). Nos Estados Unidos, entendem-se, como microcervejaria, todas as empresas que produzem até 56.700 litros por ano (NEVES, 1996).

Na última década, a produção de cerveja no Brasil cresceu 64\%. Passou dos 8,2 bilhões de litros registrados em 2003 para 13,4 bilhões de litros em 2013. O país já é o terceiro maior produtor do mundo, atrás apenas dos Estados Unidos e da China. Segundo 
uma pesquisa feita pelo Ibope em novembro de 2013, a cerveja é a bebida preferida dos brasileiros para os momentos de comemorações, com 64\% das preferências, seguida por espumante (10\%), vinho (5\%) e destilados (3\%). Cada brasileiro consome 66,7 litros por ano, estamos entre os 20 primeiros em consumo mundial ( CLEMENTE; PASSARELLI; PINHO, 2014).

De acordo com o Ministério da Agricultura, Pecuária e Abastecimento (Mapa), há 232 cervejarias e 1.110 tipos de cerveja registrados no país, e as empresas estão concentradas sobretudo no Sul e no Sudeste (CLEMENTE; PASSARELLI; PINHO, 2014).

\subsubsection{DEFINIÇÃO}

Segundo o Decreto ${ }^{\circ} 6.871$ de 4 de junho de 2009, que regulamenta a lei n.8.918 de 14 de julho de 1994, a cerveja é a bebida obtida por meio da fermentação alcoólica do mosto cervejeiro, oriundo do malte de cevada e água, por ação da levedura, com adição de lúpulo. O malte de cevada pode ser parcialmente substituído por outros cereais, maltados ou não, e por carboidratos de origem vegetal transformados ou não.

A cerveja é classificada pela legislação brasileira em função das características da fermentação e do produto acabado.

a) Quanto ao extrato primitivo (quantidade de sólidos solúveis em $100 \mathrm{~g} / \mathrm{mL}$ ): cerveja leve (apresenta extrato primitivo igual ou superior a cinco e inferior a dez e meio por cento em peso), cerveja comum (apresenta extrato primitivo igual ou superior a dez e meio e inferior a doze por cento em peso, cerveja extra (apresenta extrato primitivo igual ou superior a doze e inferior a quatorze) e cerveja forte (apresenta extrato primitivo superior a quatorze por cento em peso).

b) Quanto à cor: cerveja clara (com cor de menos de 20 EBC), cerveja escura (com cor de 20 ou mais EBC) e cerveja colorida (pela ação de corantes naturais, apresenta coloração diferente das definidas no padrão EBC)

c) Quanto ao teor alcoólico: cerveja sem álcool (com conteúdo em álcool menor ou igual a $0,5 \%$ em volume) e cerveja com álcool ( com conteúdo em álcool igual ou superior a $0,5 \%$ em volume, constando no rótulo o percentual de álcool) 
d) Quanto à proporção de malte de cevada: cerveja puro malte (contém 100\% de malte de cevada em peso como fonte de açúcares), cerveja (contém $55 \%$ ou mais de malte de cevada) e cerveja com o nome do vegetal predominante (contém mais de $25 \%$ e menos que $55 \%$ de malte de cevada).

e) Quanto à fermentação: de baixa fermentação (Lager) e de alta fermentação (Ale).

\subsubsection{Cervejas Ale e Lager}

\subsubsection{Cervejas Ale}

As cervejas Ale são aquelas cuja fermentação se processa em temperaturas superiores a $20^{\circ} \mathrm{C}$, ficando a levedura na superfície das dornas (OETTERER, 2006). Atualmente, como a maioria das cervejarias utilizam tanques fechados, as leveduras atuam em todos os seus níveis, e não apenas na superfície (BELTRAMELLI, 2012).

A superfície celular das leveduras de alta fermentação está coberta por pequenas protuberâncias microfibilares, que lhes confere uma aspereza que permite que as células fiquem em suspensão durante a fermentação (HORNSEY, 2003).

Esse tipo de fabricação de cerveja é o processo mais antigo de produção que as cervejas do tipo Lager. São bebidas que normalmente apresentam grau alcoólico superior a 5\% e contém mais lúpulo (OETTERER, 2006). Sua fermentação dura menos tempo que as cervejas Lager, fermentando entre 2 e 4 dias (COLE, 2012).

A variedade de levedura ale hidrolisa bem os açúcares do mosto em temperaturas mais altas, em torno de 15 a $25^{\circ} \mathrm{C}$. Por causa dessa particularidade, essas cervejas são mais aromáticas que as do tipo lager (BELTRAMELLI, 2012).

As chamadas Cask Ale ou Ale tradicional são autênticas cervejas Ale e eram produzidas com fermentação secundária ou maturação em barris de madeira. A produção desse tipo de cerveja sofreu uma grave crise nas décadas de 1960 e 1970 no Reino Unido, quando grandes empresas provocaram o fechamento de centenas de pequenos produtores no país ou acabavam comprando os concorrentes (MORADO, 2009).

Há vários tipos de cerveja do tipo Ale como: Pale, Brown, Mild Bitter, Stout e Porter, entre outras (OETTERER, 2006).

\subsubsection{Cervejas Lager}


Cervejas cuja fermentação se processa em temperaturas inferiores a $12^{\circ} \mathrm{C}$, e a levedura fica no fundo das dornas. Esse processo fermentativo geralmente é mais demorado quando comparado com as fermentações para obtenção de cerveja do tipo Ale (OETTERER, 2006). A duração da fermentação e da maturação pode ser de 4 a 12 semanas (ARAÚJO et al., 2003).

Essa cerveja só começou a ser produzida em larga escala no século passado com a descoberta da máquina frigorífica (SINDICERV, 2014). E se tornou a mais comum em todo o mundo. Esse tipo de cerveja engloba as variedades: Pilsen, Dortmunder, Viena, Munique, Bock, Weizenbier entre outras (OETTERER, 2006).

Devido às baixas temperaturas usadas no processo, os sabores e aromas das cervejas lager são mais leves, quando comparadas com o tipo ale (HARDWICK, 1995).

As cervejas do tipo lager, são elaboradas com cepas de Saccharomyces calsbergensis, enquanto as do tipo "ale", são elaboradas com cepas de Saccharomyces cerevisiae (VARNAM; SUTHERLAND, 1997).

\subsubsection{MATÉRIAS PRIMAS}

\subsubsection{1 ÁGUA}

A qualidade da bebida como o aroma e a cor podem ser afetadas pela composição da água em minerais. A água deve ser potável, não alcalina, levemente dura, com cerca de $500 \mathrm{mg} / \mathrm{L}$ de sulfato de cálcio e corrigida quimicamente, se estiver fora dos padrões (OETTERER, 2006).

A quantidade e qualidade dos sais dissolvidos e dos compostos orgânicos presentes na água influenciam os processos químicos e reações enzimáticas que ocorrem durante a fermentação e, consequentemente, na qualidade da cerveja produzida (SILVA, 2005).

A água de brassagem contribui diretamente como um ingrediente da cerveja e requer tratamento para que se enquadre nos parâmetros de qualidade necessários para ser usada no processo, pois alguns de seus atributos tem influência direta na qualidade da cerveja como pH e carga microbiana (TAYLOR, 2006).

No passado, a disponibilidade de água pode ter auxiliado na criação de determinados estilos de cerveja em algumas regiões, mas atualmente minerais podem ser 
removidos ou adicionados à água. Algumas cervejas como a da região da Boêmia são incrementadas com uma pequena porcentagem de sais na água da região. Os sabores maltados e o amargor de lúpulo presentes nas Dortmunder, são acentuados pela alta concentração de sais de cálcio, magnésio e sulfatos (MORADO, 2009).

Alguns requisitos são básicos para se obter água cervejeira de qualidade como: seguir padrões de potabilidade; apresentar alcalinidade de $50 \mathrm{mg} / \mathrm{L}$ ou menor (inferiores a $25 \mathrm{mg} / \mathrm{L}$ ); possuir concentração de cálcio ao redor de $50 \mathrm{mg} / \mathrm{L}$ (DRAGONE; ALMEIDA e SILVA, 2010).

A água a ser utilizada no processo de produção de cerveja deve apresentar características específicas para assegurar um $\mathrm{pH}$ desejável da mistura de malte e de adjuntos durante a mosturação, promover a extração dos princípios amargos e aromáticos do lúpulo, ter uma boa coagulação do material mucilaginoso durante a fervura do mosto, permitir uma fermentação asséptica e desenvolver cor, aroma e sabor característicos do tipo de cerveja a ser fabricada (AQUARONE, 2001).

A maioria dos processos na produção de cerveja ocorrem melhor ou mais rápido quanto mais ácido for o $\mathrm{pH}$, na mostura o $\mathrm{pH}$ ótimo está entre 5,2-5,5 e na fervura 5,1-5,3 (ESSLINGER; NARZISS, 2009; KUNZE, 1999).

A água utilizada na Planta Piloto de Bebidas da USP de Lorena foi analisada por Aizemberg e Almeida e Silva (2012) conforme mostra a tabela 2 demonstrando ser adequada para a produção de cervejas devido a sua baixa dureza.

Tabela 2 - Características físico-químicas da água utilizada para a produção de cervejas na Planta Piloto de Bebidas da USP de Lorena-SP.

\begin{tabular}{lc}
\hline \multicolumn{1}{c}{ Parâmetros } & Valores Observados \\
\hline pH & 6,66 \\
Odor & Inodora \\
Sabor & Livre de sabor \\
Aspecto & Límpida \\
Turbidez & $0,54 \mathrm{UNT}$ \\
Cor & $<5 \mathrm{mg} \mathrm{Pt} / \mathrm{L}$ \\
Dureza total & $26 \mathrm{mg} / \mathrm{L} \mathrm{CaCO}$ \\
Cloretos & $1,2 \mathrm{mg} / \mathrm{L}$ \\
Magnésio & $0,935 \mathrm{mg} / \mathrm{L}$ \\
Zinco & $5,28 \mathrm{mg} / \mathrm{L}$ \\
Nitrato & $0,19 \mathrm{mg} / \mathrm{L}$ \\
Ferro & $0,055 \mathrm{mg} / \mathrm{L}$ \\
\hline
\end{tabular}

Fonte: Aizemberg; Almeida e Silva (2012) 
Atualmente, a tecnologia de tratamentos de águas evoluiu e hoje é possível teoricamente, adequar a composição de qualquer água às características desejadas como as técnicas de desionização e osmose reversa. Mas como esses processos são muito caros, as cervejarias preferem ainda escolher a localização de suas fábricas (CARVALHO et al. 2009).

\subsubsection{MALTE}

A cevada é uma gramínea pertencente ao gênero Hordeum cujos grãos na espiga, alinhados em duas ou seis fileiras, são envoltos por diversas camadas celulósicas (DRAGONE; ALMEIDA e SILVA, 2010). A cevada de seis fileiras, quando comparada com a de duas, apresenta menor teor de amido, maior riqueza protéica (enzimática) e possuem mais cascas. Por isto, este tipo de cevada pode apresentar alguma dificuldade na produção de malte, menor rendimento na mosturação, mas por outro lado facilita a filtração do mosto (AQUARONE, 2001).

Geralmente o malte é o grão de cevada parcialmente germinada e seca, responsável pelo teor alcoólico e cor da cerveja. Pode ser substituído por outros cereais como milho, arroz e trigo, porém o mais utilizado e apropriado é o malte de cevada por possuir características mais apropriadas como:

- substâncias do corpo farinhoso: responsáveis pela formação do extrato solúvel na elaboração do mosto.

- casca: possibilita a formação de uma camada filtrante durante a clarificação do mosto.

- embrião: quando germina, ativa as enzimas fundamentais para a elaboração do mosto. (OETTERER, 2006).

Além disso, a cevada malteada apresenta em sua composição alto teor de amido, ou de extrato fermentável. A proteína encontra-se em quantidade e qualidade suficiente para a nutrição das leveduras durante a fermentação, como também para a formação de espuma no produto final. A cevada malteada confere sabor, odor e corpo característicos à cerveja (AQUARONE, 2001).

Após a colheita, os grãos são armazenados em silos, aguardando o envio para a maltaria, onde a cevada se transformará em malte. Depois a semente é colocada em condições favoráveis de germinação, controlando-se a temperatura, umidade e aeração, interrompendo a germinação quando o grão iniciar a criação de uma nova planta. Nessa 
fase, o amido presente nos grãos malteados, apresentarão cadeias menores assim tornando-se mais solúvel, possuindo enzimas fundamentais para o processo cervejeiro (DRAGONE; ALMEIDA e SILVA, 2010).

O grão de cevada é a principal fonte de amido. Esse amido é convertido em açúcares, como a maltotriose, maltose e glicose, na produção do mosto, durante a primeira fase de preparo da bebida. Depois, a levedura irá converter os açúcares fermentáveis em álcool e gás carbônico (MORADO, 2009).

$\mathrm{O}$ processo de secagem e de torrefação do malte determina a cor, o aroma (caramelo, chocolate, café etc.) e algumas outras características importantes do produto final, sua escolha permite ao cervejeiro uma ampla variedade de combinações. Algumas cervejas utilizam apenas um tipo de malte, outras usam vários deles combinados (MORADO, 2009).

\subsubsection{LÚPULO}

O lúpulo (Humulus lupulus) pertence à família Cannabinaceae e é originária de zonas temperadas. Apresenta flores masculinas e femininas, porém o interesse industrial é nas flores femininas (AQUARONE, 2001).

As flores femininas não fecundadas contêm lupulina, um material resinoso, amargo onde predominam antocianinas, taninos e $\alpha$-ácidos (humulonas). Essa planta foi originalmente acrescentada à cerveja como conservante por conter substâncias bacteriostáticas, porém tem outras duas funções: a aromática e a que propicia sabor amargo. A característica aromática vem dos óleos essenciais do lúpulo, e o amargor da lupulina (OETTERER, 2006).

Apesar de serem voláteis, ocorrendo perdas de até $98 \%$ no decorrer do processo cervejeiro, os óleos essenciais conferem à cerveja o caráter aromático do lúpulo. E as resinas do lúpulo, que podem ser resinas brandas totais, apresentam $\alpha$-ácidos ou humulonas que após isomerização tonam-se solúveis e responsáveis pelo principal amargor da cerveja (DRAGONE e ALMEIDA e SILVA, 2010).

Os principais compostos amargos das resinas são os $\alpha$-ácidos e os $\beta$-ácidos. $O$ amargor depende, principalmente, da extensão em que os $\alpha$-ácidos são isomerizados a 
iso- $\alpha$-ácidos. Esta conversão ocorre quando a mistura é submetida a uma ebulição por tempo prolongado ou a um tratamento alcalino (KUNZE, 1996).

O amargor é classificado pela unidade internacional de amargor IBUInternational Bitterness Unit; e a escala de IBU varia de 5-17 IBU's para cervejas do tipo American Lager, chegando a 1000 IBU's para o estilo Imperial India Pale Ale (WYLER, 2013).

Os lúpulos podem ser classificados em lúpulo de aroma e de amargor. O lúpulo de aroma é rico em óleos essenciais e pobre em alfa-ácidos. E o de amargor é pobre em óleos essenciais e rico em alfa-ácidos (HOUGH, 1990; KUNZE, 1999).

Ao contrário do malte, o lúpulo não altera o teor alcoólico nem o corpo da cerveja. Sua presença é fundamental para conferir à bebida o amargor característico das cervejas. Além disso, seus aromas, que variam do herbal ao floral, fazem parte da essência de muitos estilos de cerveja (MORADO, 2009).

O lúpulo é adicionado na fase final da fervura do mosto e pode ser na forma de cones florais secos, pellets ou extratos (OETTERER, 2006).

Devido à instabilidade dos componentes da planta do lúpulo, facilmente oxidáveis, a sua qualidade vai diminuindo se não houver demasiado cuidado na armazenagem. Para evitar esses contratempos foram surgindo formas de emprego estáveis e algumas passíveis de armazenamento à temperatura ambiente como os extratos e pellets (CRUZ, 2007).

\subsubsection{LEVEDURA CERVEJEIRA}

São microorganismos eucariotos, fungos unicelulares e do gênero Saccharomyces. Metabolizam os açúcares do mosto fornecidos pelo malte e pelos adjuntos, transformando-os em álcool e $\mathrm{CO}_{2}$ (OETTERER, 2006). Os açúcares fermentáveis por Saccharomyces cerevisiae na cerveja são glicose, frutose, maltose, maltotriose e sacarose (SILVA, 2005).

No passado, a nomenclatura das espécies de leveduras selvagens variava de acordo com as características fenotípicas, nutricionais ou outros critérios que resultam em classificações distintas, fazendo com que fossem classificadas em diferentes espécies, tais como S. uvarum, S. cerevisiae e S. carlsbergensis. Porém, análises feitas com o DNA 
dessas espécies revelou bases comum entre elas, assim os taxinomistas designaram todas as cepas usadas na produção de cerveja como Saccharomyces cerevisiae (RUSSEL, 2006).

As leveduras são classificadas de acordo com o seu comportamento durante o processo fermentativo. Leveduras classificadas como "Lager" ou de baixa fermentação, decantam no fundo do fermentador e leveduras do tipo "Ale" ou alta fermentação, podem flutuar sobre a superfície do mosto (HOUGH, 1985).

Por ser fundamental na formação de aromas na cerveja, é de grande importância que a cultura de leveduras seja a mais pura possível, isenta de leveduras "mutantes" e de microorganismos contaminantes (bactérias e leveduras selvagens). Por isso a assepsia das cervejarias é fundamental (MORADO, 2009).

O tipo e a concentração de vários outros produtos de excreção formados durante a fermentação são quem determinam o sabor da cerveja. Sua formação depende do balanço metabólico global do cultivo da levedura. Vários fatores podem afetar esse balanço e assim o sabor da cerveja, incluindo a cepa da levedura, a temperatura e o pH de fermentação, o tipo e proporção de adjunto, o modelo de fermentador e a concentraçãodo mosto (DRAGONE; ALMEIDA e SILVA, 2010).

Três características têm importância fundamental em qualquer processo de seleção da levedura cervejeira: a) a levedura deve produzir cerveja de sabor e odor agradáveis, que não são conferidos só pela atividade da levedura, mas pela matéria-prima e pelas técnicas de processamento também. b) espera-se que a levedura aumente sua massa de 3 a 5 vezes durante a fermentação. c) a habilidade da levedura flocular ou não, e se os flocos sobem ao topo ou decantam na base do fermentador, determina o tipo de fermentação, a forma de separação da levedura, o tipo de cerveja obtida, etc (AQUARONE, 2001).

\subsubsection{ADJUNTOS}

Os adjuntos na produção de cerveja podem ser definidos como qualquer fonte de carboidrato, diferente do malte de cevada, que contribua com açúcares fermentescíveis na composição do mosto (STEWART, 2000).

Os adjuntos são empregados principalmente por razões econômicas, apresentam menor custo na produção de extrato. Melhoram a qualidade físico-química e sensorial da cerveja. Podem ser considerados como diluidores de todos os componentes do mosto 
cervejeiro, exceção feita aos carboidratos. Reduzem o teor de nitrogênio (proteína) solúvel do mosto, diminuindo a ocorrência de infecção lática na cerveja, melhora a estabilidade coloidal e aumenta a vida de prateleira do produto. As cervejas que utilizam adjuntos apresentam normalmente cor mais clara e maior brilho (AQUARONE, 2001).

Além dos adjuntos serem mais econômicos, o uso de matérias-primas diferentes do malte de cevada podem possuir a vantagem de serem disponíveis em regiões não apropriadas à produção de cevada e apresentar características especiais de cor e aroma em novos tipos de bebida (MEUSSDOERFER; ZARNKOW, 2009).

Os adjuntos do malte mais utilizados são milho, arroz, trigo e cevada não malteada. Indústrias vêm adotando também o xarope de alta maltose como fonte de açúcar fermentescível. A maltose do xarope é substrato direto para a ação das maltases presentes no malte (OETTERER, 2006).

Quando da utilização de adjuntos na forma de açúcares, como cristais ou xaropes concentrados, há vantagens sobre os cereais, como: baixos teores de proteínas, não precisar de pré-tratamento (sacarificação) e menores volumes de armazenamento, devido à sua maior concentração (SILVA, 2005).

Fontes de carboidratos de origem vegetal como a mandioca e batata já foram utilizados como adjuntos no processo de obtenção de cerveja. A banana, beterraba, pupunha, pinhão, frutas tropicais e caldo de cana tem sido pesquisados como possíveis substitutos de parte do malte de cevada e também como aromatizantes da bebida. Algumas microcervejarias tem utilizado também o limão, cereja, morango, abacaxi, kiwi, maça, chocolate e até mesmo rosa, como aromatizante da bebida (DRAGONE e ALMEIDA e SILVA, 2010).

Venturini Filho e Cereda (1998) utilizaram como adjuntos de suas cervejas, hidrolisados de mandioca e milho. Utilizando enzimas comerciais Termamyl e Fungamyl obtiveram os hidrolisados na liquefação e sacarificação dessas matérias-primas. A conclusão desse trabalho foi que a fécula de mandioca apresenta potencial de uso para a produção de xarope de maltose para uso na produção de cervejas.

Estudos envolvendo a utilização da fécula de batata apresentou potencial uso como adjunto amiláceo pelo seu elevado teor de amido e baixo teor de proteínas e de óleo, diminuindo assim o risco de turvação, melhorando a estabilidade da espuma da cerveja e reduzindo gastos com estabilizantes (MATOS et al., 2005). 
Cervejas utilizando sorgo como adjunto foram estudados por Goode e Arendt (2003). Eles compararam cervejas com sorgo não malteado com cervejas com malte de cevada e não houve diferença significativa quanto ao aroma. Os avaliadores preferiram a cerveja de sorgo à puro malte.

Carvalho (2009) utilizou como adjunto de cervejas a banana. Em seu estudo a fruta além de ser usada como adjunto do malte, foi usada também como aromatizante natural. A análise sensorial das amostras demonstraram que em relação aos testes de preferência, as cervejas de banana foram estatisticamente preferidas em relação às amostras do mercado.

Andrade (2007) avaliou o uso de arroz preto em várias concentrações como adjunto. Mas concluiu que outros estudos deveriam ser feitos de modo a aumentar a eficiência da mosturação, utilizando-se enzimas comerciais ou malte com maior poder diastático. Santos (2011) também utilizou o arroz preto como adjunto mas, utilizou a enzima $\alpha$-amilase como forma a otimizar o processo. $O$ processo apresentou bom rendimento fermentativo e eficiência de fermentação.

Há perspectiva de que fatores econômicos levem a um aumento na utilização de adjunto pelas cervejarias em todo o mundo (AQUARONE, 2001).

\subsection{AROMATIZANTES}

Segundo a definição dada pela Legislação Brasileira ( Resolução nº 104, de 14 de maio de 1999 da Anvisa) aromatizantes são substâncias ou misturas de substâncias, com propriedades odoríferas e/ou sápidas, capazes de conferir ou intensificar o aroma e/ou sabor dos alimentos. São classificados em aromas naturais ou sintéticos.

\subsubsection{Aromatizantes naturais}

Os aromas naturais são obtidos mediante métodos físicos, microbiológicos ou enzimáticos, a partir de matérias-primas aromatizantes naturais.

Matérias-primas aromatizantes naturais são os produtos de origem animal ou vegetal, aceitáveis para consumo humano, que contenham substâncias odoríferas e/ou sápidas, seja em seu estado natural ou após um tratamento adequado como torrefação, 
cocção, fermentação, enriquecimento enzimático, tratamento enzimático ou outros (GAVA; SILVA; FRIAS, 2009).

\subsubsection{Aromatizantes sintéticos}

Compostos obtidos por processos químicos, podem ser aromas idênticos ao natural e artificiais.

Aromas idênticos ao natural são substâncias obtidas por síntese e aquelas isoladas por processos químicos, a partir de matérias-primas de origem animal, vegetal ou microbiana, que apresentam uma estrutura química idêntica às substãncias presentes nas matérias-primas naturais.

Aromatizantes artificiais são compostos obtidos por síntese, que ainda não tenham sido identificados em produtos de origem animal, vegetal ou microbiana (GAVA; SILVA; FRIAS, 2009).

\subsection{PRODUÇÃO DE CERVEJA}

\subsubsection{FLUXOGRAMA DO PROCESSO}


Figura 1. Esquema simplificado do processo cervejeiro

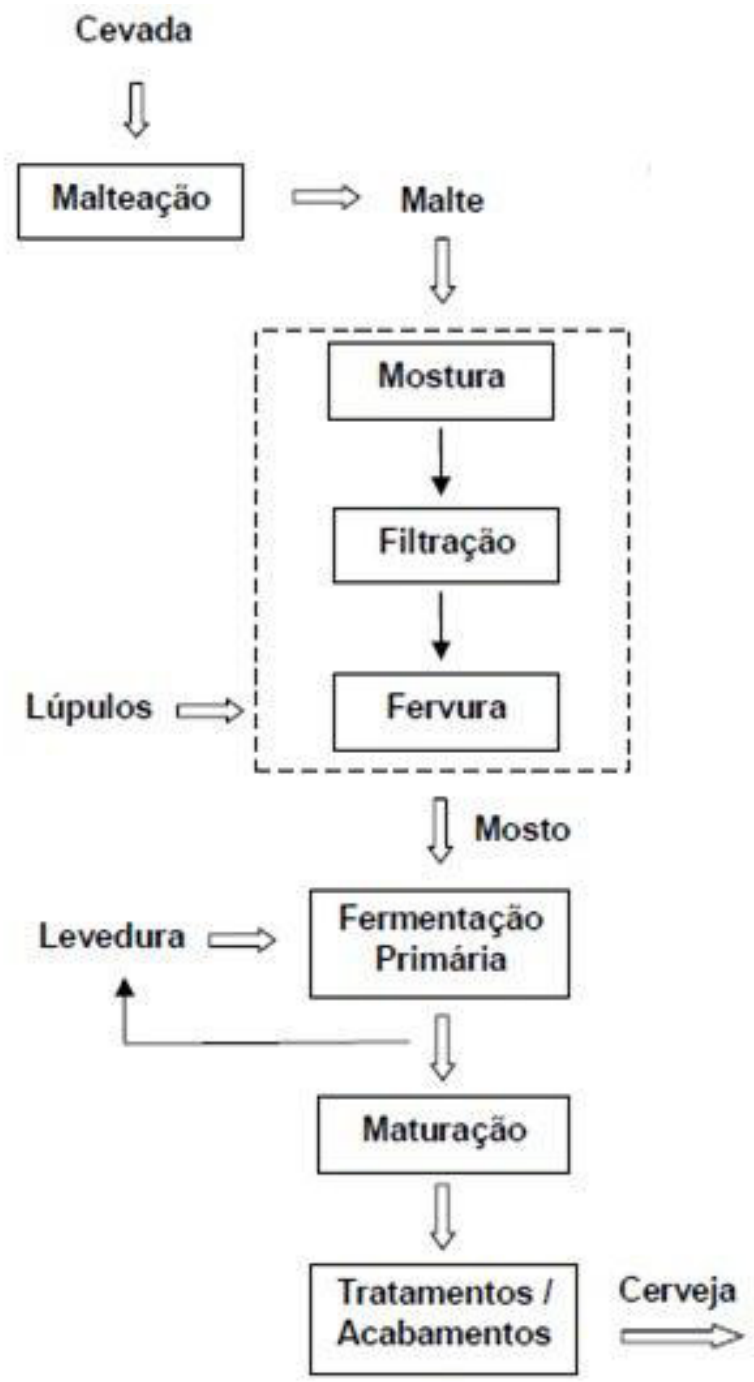

Fonte: Modificado de LINKO et al. (1998)

\subsubsection{MALTAGEM}

O processo de maltagem é constituído de três etapas: maceração, germinação e secagem. Na maceração, a cevada é colocada em tanques cilíndricos para ser macerada com água. A água deve estar na temperatura entre 5 e $18^{\circ} \mathrm{C}$, e é trocada a cada 6-8 horas. O oxigênio necessário a respiração do embrião da cevada é fornecido através da injeção de ar nos tanques. O processo termina em dois dias, quando a cevada atinge $42-48 \%$ de umidade, nesse ponto há o aparecimento da radícula (AQUARONE, 2001).

A cevada é colocada para germinar em compartimentos que apresentam fundo falso perfurado onde ar úmido em fluxo ascendente ou descendente atravessam o leito de 
cevada e mantém a temperatura dos grãos na faixa de 15 a $21^{\circ} \mathrm{C}$. O acompanhamento da germinação é feito pela observação do crescimento do embrião, pelo odor e pela textura dos grãos. Essa etapa é encerrada quando a estrutura embrionária atinge dois terços do comprimento do grão (AQUARONE, 2001).

Na germinação, quimicamente há a formação das enzimas que irão hidrolisar o amido e as proteínas no ponto adequado para o início da produção da cerveja (MORADO, 2009).

$\mathrm{Na}$ última etapa o processo de germinação é interrompido pela secagem dos grãos de malte. $\mathrm{O}$ ar de secagem, quente e seco, passa através do leito de malte em fluxo ascendente ou descendente. $\mathrm{O}$ processo de secagem ocorre em três etapas distintas. $\mathrm{Na}$ primeira, o ar fica na temperatura de $49-60{ }^{\circ} \mathrm{C}$ e há a remoção da água livre. Na segunda aumenta-se a temperatura do ar até $71^{\circ} \mathrm{C}$ e o malte atinge $12 \%$ de umidade. Na última etapa a temperatura do ar passa a ser $88^{\circ} \mathrm{C}$ e a umidade final é de 4-5\% (AQUARONE, 2001).

A secagem tem grande importância na conservação do malte, pois, eliminando-se a umidade, diminui-se o risco de crescimento de fungos; também favorece a estocagem, uma vez que torna o malte mais leve (MORADO, 2009).

\subsubsection{PRODUÇÃO DO MOSTO}

$\mathrm{O}$ malte é pesado em balanças apropriadas, e enviado para a moagem. $\mathrm{Na}$ moagem, o grão deve ter a sua casca rasgada longitudinalmente, para deixar exposto o endosperma amiláceo. Este, sim, deve ser triturado para facilitar o ataque das enzimas durante a mosturação (AQUARONE, 2001).

A moagem do malte pode ser conduzida em moinho de rolos em duas etapas, sendo regulados a uma distância de $0,6 \mathrm{~mm}$ na primeira etapa, e $0,1 \mathrm{~mm}$ na segunda. Essa etapa tem influência direta sobre a rapidez das transformações físico-químicas, no rendimento e na qualidade do produto final (DRAGONE; ALMEIDA e SILVA, 2010).

Existem dois tipos básicos de moagem: moagem com rolos ou moagem em moinhos do tipo martelo. A diferença básica é que na moagem com rolos a casca é preservada, enquanto o moinho do tipo martelo reduz o malte praticamente a pó. Essa diferença exerce influência no tipo de filtração (MORADO, 2009). O adequado são as 
cascas permanecerem o mais intactas possíveis, para assegurar um leito filtrante apropriado.

Na mosturação ou brassagem, as matérias-primas cervejeiras (água, malte, lúpulo e adjunto) vão ser transformadas em mosto (AQUARONE, 2001). A mostura consiste em adicionar água ao malte moído, submetendo-o a diferentes temperaturas por períodos de tempo determinados. Como resultado, obtém-se uma solução adocicada, denominada mosto, que ainda contém bagaço de malte (MORADO, 2009).

A mosturação tem por objetivo solubilizar as substâncias do malte diretamente solúveis em água e, com o auxílio das enzimas, solubilizar as substâncias insolúveis, promovendo a gomificação e posterior hidrólise do amido a açúcares bebida (DRAGONE; ALMEIDA e SILVA, 2010).

As enzimas são proteínas que catalizam as reações químicas pouco espontâneas e muito lentas, aumentando a velocidade com que ocorrem e diminuindo a energia necessária. A atividade da enzima depende da temperatura e do $\mathrm{pH}$ do meio (WYLER, 2013).

O malte moído é misturado com a água quente no interior de um tanque chamado "mosturador" ou "tina de mosturação", resultando numa mistura que fica em repouso a $40^{\circ} \mathrm{C}$ por duas horas. Ao final da primeira hora, um terço da mistura é enviada para uma caldeira, onde será fervida por 30 min. O material fervido retorna ao mosturador, elevando a temperatura da mistura para $52-54^{\circ} \mathrm{C}$, ótima para a atividade das enzimas proteolíticas. Após um período nessa temperatura, repete-se a operação por mais duas vezes, fazendo a temperatura atingir $65^{\circ} \mathrm{C}$, ótima para atividade das amilases, e $73-76^{\circ} \mathrm{C}$, ótima para a filtração do mosto (AQUARONE, 2001). 
Tabela 3. Temperatura, $\mathrm{pH}$ e alvo de ação das enzimas

\begin{tabular}{|c|c|c|c|}
\hline Enzimas & $\begin{array}{c}\text { Temperatura } \\
\text { Ótima }\left({ }^{\circ} \mathbf{C}\right)\end{array}$ & pH ótimo & Atuação \\
\hline Hemicelulases & 40 a 45 & 4,5 a 4,7 & $\begin{array}{l}\text { Decomposição da } \\
\text { hemicelulose em } \\
\text { glucanas de média e } \\
\text { baixa massa molar }\end{array}$ \\
\hline Exopeptidases & 40 a 50 & 5,2 a 8,2 & $\begin{array}{l}\text { Decomposição das } \\
\text { proteínas de alto e } \\
\text { médio peso } \\
\text { molecular em } \\
\text { aminoácidos }\end{array}$ \\
\hline Endopeptidases & 50 a 60 & 5,0 & $\begin{array}{l}\text { Decomposição das } \\
\text { proteínas em } \\
\text { produtos } \\
\text { intermediários de } \\
\text { alto e médio peso } \\
\text { molecular }\end{array}$ \\
\hline Dextrinase & 55 a 60 & 5,1 & $\begin{array}{l}\text { Decomposição do } \\
\text { amido em maltose e } \\
\text { maltotriose pela } \\
\text { hidrólise das } \\
\text { ligações } \alpha, 1 \rightarrow 6\end{array}$ \\
\hline Beta-amilase & 60 a 65 & 5,4 a 5,6 & $\begin{array}{l}\text { Decomposição do } \\
\text { amido em maltose } \\
\text { pela hidrólise das } \\
\text { ligações } \alpha, 1 \rightarrow 4\end{array}$ \\
\hline Alfa-amilase & 70 a 75 & 5,6 a 5,8 & $\begin{array}{l}\text { Decomposição do } \\
\text { amido em dextrinas } \\
\text { inferiores pela } \\
\text { hidrólise das } \\
\text { ligações } \alpha, 1 \rightarrow 4\end{array}$ \\
\hline
\end{tabular}

Fonte: TSCHOPE (2001)

No final da mosturação é realizado o teste com solução de iodo $0,2 \mathrm{~N}$ a fim de verificar a sacarificação do malte. Após a confirmação da completa hidrólise do amido, pela ausência da coloração roxo-azulada, característica da reação do iodo com o amido, em temperatura ambiente, a solução é aquecida até $76^{\circ} \mathrm{C}$ com o objetivo de inativar as enzimas presentes (DRAGONE; ALMEIDA e SILVA, 2010).

Após o final da mosturação, o mosto deve ser separado da parte sólida insolúvel da massa. Para isso, a filtração é feita em duas etapas: a) na primeira, a fração líquida atravessa o leito filtrante, dando origem ao mosto primário. b) na segunda, o resíduo sólido é lavado com água (AQUARONE, 2001). 
A camada filtrante é lavada com uma certa quantidade de água (denominada água secundária) à $75^{\circ} \mathrm{C}$, visando aumentar a extração de açúcar e consequentemente, elevar o rendimento do processo (DRAGONE; ALMEIDA e SILVA, 2010).

\subsubsection{FERVURA DO MOSTO}

A fervura do mosto tem por objetivo conferir-lhe estabilidade biológica, bioquímica e coloidal (AQUARONE, 2001).

Durante a fervura, a flora microbiana, presente no mosto que resistiu ao processo de mosturação e filtragem, é eliminada. $\mathrm{O}$ pH ácido (menor que 5,5) e as substâncias extraídas do lúpulo durante essa fase contribuem para a esterilização do mosto (AQUARONE, 2001).

Com o acréscimo do lúpulo, o mosto filtrado é sbmetido à fervura, visando a intativação de enzimas, esterilização do mosto, coagulação proteica, extração de compostos amargos e aromáticos do lúpulo, formação de substâncias constituintes do aroma e sabor, evaporação de água excedente e de componentes aromáticos indesejáveis ao produto final (DRAGONE; ALMEIDA e SILVA, 2010).

A enzima alfa-amilase, que após a mosturação e filtragem poderia apresentar alguma atividade, é agora inativada. As proteínas e os taninos são coagulados e eliminados do mosto na forma de "trub", um resíduo mucilaginoso semelhante a um lodo (AQUARONE, 2001).

O desenvolvimento de cor é função da intensidade da fervura. A produção de cor está ligada à caramelização de açúcares, formação de melanoidinas e oxidação de taninos (AQUARONE, 2001).

Parte das proteínas contidas no mosto aglutina-se durante a fervura, formando o chamado "trub". Uma boa separação do trub é importante para que a cerveja tenha estabilidade no brilho e um sabor mais suave (MORADO, 2009).

Terminada a fervura, o "trub" e o bagaço do lúpulo são separados normalmente em tanques de decantação denominados "whirpool". Depois o mosto clarificado segue para o resfriamento (AQUARONE, 2001). O "whirlpool” utiliza a força centrípeta para fazer o trub se acumular no centro do tanque, para depois ser descartado (MORADO, 2009). 
O refriamento do mosto tem por objetivo reduzir a sua temperatura de $100^{\circ} \mathrm{C}$ para a temperatura adequada de inoculação da levedura, que é de 14 a $16^{\circ} \mathrm{C}$ na fermentação alta e de 6 a $12^{\circ} \mathrm{C}$ na baixa fermentação (AQUARONE, 2001). O resfriamento deve ser feito o mais rápido possível, para evitar a formação de aromas indesejáveis e o risco de contaminação (MORADO, 2009).

\subsubsection{FERMENTAÇÃO}

A fermentação alcoólica é a assimilação de carboidratos com produção de etanol (álcool etílico) e gás carbônico, objetivando a produção de energia para as funções vitais do microorganismo. Para a produção de cerveja, a fermentação inicia-se com a inoculação da levedura no mosto resfriado (OETTERER, 2006).

Todos os carboidratos fermentescíveis (maltose, maltotriose, glicose etc.) são metabolizados pela levedura. Além disso, numerosos subprodutos se desenvolvem durante a fermentação e muitos componentes do mosto são assimilados pela levedura. Todos os compostos envolvidos com a assimilação, formação de produtos e subprodutos, influenciam no aroma, no paladar e nas características finais da cerveja pronta (DRAGONE; ALMEIDA e SILVA, 2010).

Muitos compostos são formados durante a fermentação, como subprodutos do metabolismo da levedura. Alguns deles resultam em aromas agradáveis outros não. Procura-se, então, administrar a fermentação de modo a favorecer a produção e a manutenção dos aromas desejáveis e a eliminação dos indesejáveis. Os fatores mais importantes que concorrem pra isso são: a temperatura de fermentação, a duração do processo, a contrapressão, a escolha adequada da levedura e a quantidade dela a ser empregada (MORADO, 2009).

Nos primeiros momentos de fermentação a concentração de açúcares é elevada. Os principais açúcares fermentáveis do mosto são a maltose e a glicose. Outros nutrientes importantes contidos no mosto são os aminoácidos e alguns sais minerais (MORADO, 2009).

Durante a fermentação há um deslocamento do $\mathrm{pH}$ de 5,2 para 3,8, mais favorável para a levedura. Pode-se ter maior ou menor concentração de álcool na mistura no final da fermentação dependendo da concentração de açúcares fermentescíveis no mosto (OETTERER, 2006). 
A) Alta fermentação

Nesse tipo de fermentação a temperatura inicial do mosto deve estar na faixa de 14 a $20^{\circ} \mathrm{C}$. Após 36 horas de fermentação, a temperatura do mosto é elevada para 20 a $25^{\circ} \mathrm{C}$, e depois de $72 \mathrm{~h}$, diminui-se a temperatura para $17^{\circ} \mathrm{C}$. Nas últimas $10 \mathrm{~h}$ de fermentação, as leveduras tendem a subir para a superfície do mosto (OETTERER, 2006).

B) Baixa fermentação

A temperatura inicial do mosto deve estar entre 6 e $12^{\circ} \mathrm{C}$. A temperatura do mosto é elevada para 10 a $15^{\circ} \mathrm{C}$ nos primeiros 3 a 5 dias da fermentação. No final, a temperatura é diminuída e a levedura decanta (OETTERER, 2006).

Durante o processo de fermentação, uma substância exerce um papel importante na formação e eliminação de aromas: o diacetil que é formado pela levedura durante o processo de fermentação, e uma alta concentração deste composto revela um aroma de manteiga rançosa. No final da fermentação, o diacetil é reabsorvido pela levedura (MORADO, 2009).

A alta concentração de diacetil não é desejada na bebida. Pode ser causada pela baixa hidrólise das proteínas que desse modo não fornecem os compostos nitrogenados necessários ao crescimento das leveduras gerando assim o desenvolvimento de subprodutos indesejáveis na fermentação como o diacetil (KREISZ, 2009).

\subsubsection{MATURAÇÃO}

A maturação é um repouso da cerveja em baixas temperaturas, de 0 a $3^{\circ} \mathrm{C}$ para ocorrer a precipitação das leveduras e proteínas, diminuindo-se assim a turbidez e resultando na clarificação da cerveja. O odor e o sabor da bebida também são apurados por meio do aumento dos teores de ésteres e da redução de diacetil, acetaldeído e ácido sulfídrico (OETTERER, 2006).

Ao iniciar-se a maturação, a maior parte dos açúcares já foi metabolizada e transformada em álcool etílico, dióxido de carbono, glicerol, ácido acético, alcoóis superiores e ésteres (MORADO, 2009).

A maturação pode durar de 2 a 4 semanas e tem por objetivo: a) iniciar a clarificação da cerveja mediante a remoção, por sedimentação, das células de levedura, de 
material amorfo e de componentes que causam turbidez a frio na bebida; b) saturar a cerveja com gás carbônico, através da fermentação secundária; c) melhorar o odor e sabor da bebida, através da redução da concentração de diacetil, acetaldeído e ácido sulfídrico, bem como o aumento do teor de éster; d) manter a cerveja no estado reduzido, evitando que ocorram oxidações que comprometam sensorialmente a bebida (AQUARONE, 2001).

Durante o período de maturação são formados ésteres responsáveis pelo aroma e sabor que caracterizam a cerveja; entre os ésteres predominam o acetato de etila e o acetato de amila (DRAGONE; ALMEIDA e SILVA, 2010). É nessa etapa que ocorre a carbonatação natural da bebida, como efeito da contrapressão exercida no próprio tanque de maturação pelo gás carbônico na fermentação do extrato que ainda resta (MORADO, 2009).

A fermentação primária requer um tempo de aproximadamente sete dias para ser completada e a maturação (ou fermentação secundária) pode levar várias semanas. Atualmente, com o emprego de cepas selecionadas de leveduras, é possível produzir cervejas entre 12 e 15 dias (WILLAERT; NEDOVIC, 2006).

Depois da maturação, a cerveja pode passar pelos processos de: filtração (para remover leveduras, partículas coloidais e outras substâncias insolúveis), carbonatação (se no final da maturação, a cerveja apresentar carbonatação natural inferior ao desejado), envase (engarrafamento ou enlatamento) e pasteurização (para aumentar o tempo de vida de prateleira, a cerveja é submetida a um aquecimento de $60^{\circ} \mathrm{C}$ e posterior resfriamento) (ESSLINGER; NARZISS, 2009; KUNZE, 1999; MORADO, 2009).

\subsection{ANÁLISE SENSORIAL}

Análise Sensorial é uma ciência que objetiva, principalmente, estudar as percepções, sensações e reações do consumidor sobre as características dos produtos, incluindo sua aceitação ou rejeição (MINIM; LUCIA; CARNEIRO, 2013).

A análise sensorial é realizada em função das respostas transmitidas pelos indivíduos às várias sensações que se originam de reações fisiológicas e são resultantes de certos estímulos, gerando a interpretação das propriedades intrínsecas aos produtos. Para isto é necessário que haja entre indivíduos e produtos, contato e interação. O estímulo é medido por processos físicos e químicos e as sensações por efeitos psicológicos, enquanto 
as sensações produzidas podem dimensionar a intensidade, extensão, duração, qualidade, gosto ou desgosto em relação ao produto avaliado. Nesta avaliação, os indivíduos, por meio dos próprios orgãos sensórios, utilizam os sentidos da visão, olfato, audição, tato e gosto (IAL, 2008).

Por meio da análise sensorial, as características ou propriedades de interesse relativas à qualidade sensorial do alimento são identificadas e adequadamente estudadas, com base em metodologias sensoriais de coleta de dados e em métodos estatísticos de avaliação e interpretação dos resultados do estudo sensorial desse alimento (MINIM; LUCIA; CARNEIRO, 2013).

\subsubsection{Testes de Aceitação}

Os testes de aceitação são usados quando o objetivo é avaliar se os consumidores gostam ou desgostam do produto. As escalas utilizadas nestes testes podem ser balanceadas ou não balanceadas (MINIM; REIS, 2013).

Há várias escalas para medir a aceitação, sendo as mais utilizadas a hedônica, a de atitude e a do ideal.

\subsubsection{Escala hedônica}

A escala hedônica é uma escala facilmente compreendida pelos consumidores. Nela, o consumidor expressa sua aceitação pelo produto, seguindo uma escala previamente estabelecida que varia gradativamente, com base nos atributos "gosta" e “desgosta”. As escalas hedônicas podem ser: verbais, faciais e não estruturada (MINIM; REIS, 2013).

Nas escalas verbais, a escolha apropriada das palavras ou frases é de extrema importância, pois deverá dar uma ideia de ordem sucessiva dos intervalos na escala e também facilitar a decisão do consumidor em suas respostas, evitando expressões ambíguas que possam causar confusão e dificultar a decisão do consumidor (MINIM; REIS, 2013).

As escalas faciais são usadas para crianças e, ou, pessoas que não sabem ler. São descritas como uma série de desenhos com expressões faciais que indicam se o produto vai ser aceito ou recusado. 
A escala hedônica não estruturada é uma linha demarcada no extremo esquerdo com o termo "desgostei extremamente", e no direito, "gostei extremamente" (MINIM; REIS, 2013).

\subsubsection{Escala de Atitude}

Mede o grau de aceitação do produto com base em atitudes do consumidor em relação à frequência em que estaria disposto a consumir o produto em determinado período (MINIM; REIS, 2013).

\subsubsection{Escala do Ideal}

São escalas por meio das quais se obtêm informações sobre qual seria a intensidade de determinado atributo sensorial considerado ideal pelo consumidor (MINIM; REIS, 2013).

Entre os métodos sensoriais este é o mais adequado para se medir a quantidade ideal de um determinado componente a ser adicionado para provocar a melhor aceitação e preferência de um grupo de julgadores. A escala do ideal é o método afetivo mais aplicado, tanto quanto à confiabilidade e validade de seus resultados como a simplicidade em sua aplicação. Nessa análise, os julgadores avaliam as amostras e registram suas respostas em escala especifica, o qual ideal essas amostras encontram-se em relação ao atributo que se deseja avaliar.

Os dados então são avaliados através de gráfico de distribuição das respostas sensoriais (em porcentagem) em função do componente que está variando (CARDOSO; BATTOCHIO; CARDELLO, 2004).

\subsection{PESQUISA MERCADOLÓGICA}

A pesquisa mercadológica é uma das ferramentas mais empregadas para a tomada de decisão no processo de inovação, desenvolvimento e geração de novos produtos. Por sua capacidade de expressar o comportamento, desejo ou necessidade dos consumidores e por tornar possível mensurar a aceitação de certo produto, muitas empresas têm 
incorporado e aperfeiçoado, continuamente, técnicas de pesquisa de mercado em suas práticas mercadológicas (MINIM; REIS, 2013).

O desenvolvimento de estratégias mercadológicas demanda conhecimentos sobre o comportamento do consumidor. Para tanto, é preciso estabelecer um elo entre o mercado e os aspectos cognitivos do ser humano, ou seja, é preciso entender o que motiva os consumidores, identificar seus valores, a forma como se processa sua aprendizagem e como se dá a sua percepção de mercado (VILAS BOAS, 2005).

Atualmente os consumidores estão mais conscientes e informados, portanto, tornase necessária a compreensão dos fatores que influenciam o comportamento do consumidor, possibilitando uma visão da dinâmica da compra. Segundo Kotler e Keller (2006), o indivíduo, como consumidor, sofre influências culturais, sociais, pessoais e psicológicas, sendo que os fatores culturais exercem maior influência. Por isso, a análise do comportamento do consumidor deve ser feita com base nos aspectos que influenciam esse comportamento (VENTURINI FILHO, 2011).

O comportamento de consumidores frente a um determinado alimento ou bebida pode variar em razão de suas diferenças em experiência, expectativa, autoestima, preferência, idade, sexo, personalidade, condição socioeconômica, grupo étnico etc. (JAEGER, 2006).

Compreender os consumidores e o processo de consumo proporciona uma série de benefícios, entre eles: o fornecimento de uma base de conhecimento, a partir da qual os pesquisadores de marketing podem analisar os consumidores; o apoio aos legisladores e controladores na criação de leis e regulamentos referentes à compra e venda de mercadorias e serviços; e o auxílio ao consumidor médio na tomada de decisões de compra (MOWEN; MINOR, 2003).

Nos últimos anos, no setor de bebidas, as empresas do setor buscam diferenciar seus produtos por meio da diversificação de sabores e dos tipos de bebidas, para assegurar fidelidade às marcas e aumentar as vendas para nichos de mercado de maior poder aquisitivo, que exigem cada vez mais produtos originais (VENTURINI FILHO, 2011).

Portanto a pesquisa de mercado objetivou gerar informações que foram usadas para identificar e mensurar oportunidades e ameaças mercadológicas, relativas ao processo de inovação, desenvolvimento e geração de um novo produto (MINIM; REIS, 2013). 
Há vários tipos de pesquisa, e cada uma delas dependerá do objetivo a ser analisado.

\subsubsection{Pesquisa exploratória}

Entrevistas pessoais ou questionários, que não representem uma amostra representativa, podem ser usadas como instrumentos de coleta de dados.

\subsubsection{Pesquisa descritiva}

Nessa pesquisa o objetivo principal é descrever e não explicar o fenômeno ou objeto estudado.

Os dados podem ser coletados por meio de métodos quantitativos, como questionários, ou por métodos qualitativos, como exemplo o grupo focal.

\subsubsection{Pesquisa Causal}

Apropriada quando se deseja estabelecer quais variáveis são as causas e efeitos de um fenômeno. 


\section{MATERIAL E MÉTODOS}

Os experimentos foram realizados na Planta Piloto de Bebidas do Departamento de Biotecnologia da Escola de Engenharia de Lorena, da Universidade de São Paulo, EEL $-\mathrm{USP}$.

\subsection{MATÉRIAS PRIMAS}

\subsection{1 ÁGUA}

A água utilizada no processo foi oriunda do poço artesiano localizado no Campus I da USP - Lorena (características físico-químicas da água utilizada para a produção de cervejas na Planta Piloto de Bebidas da USP de Lorena na página 27, Tabela 2).

\subsubsection{CEVADA MALTEADA (MALTE)}

O malte utilizado foi o malte claro, tipo Pilsen, doado pela Malteria do Vale S/A, fornecido em sacos de $50 \mathrm{~kg}$ e armazenado na câmera fria na temperatura de $0^{\circ} \mathrm{C}$.

\subsubsection{LÚPULO}

O lúpulo utilizado nos testes preliminares foi o Galena e o Hallertau Perle, na forma de peletes isomerizados, para amargor e aroma respectivamente.

Para os experimentos feitos em escala laboratorial e em escala piloto foram utilizados apenas o lúpulo Galena para amargor.

O lúpulo ficava armazenado na geladeira e na temperatura de $5^{\circ} \mathrm{C}$.

\subsubsection{CAFÉ}

O café torrado e moído tradicional (do tipo Coffea arabica) foi recebido em sacos com capacidade aproximada de $1 \mathrm{~kg}$, doados por sítios e fazendas situados em Poços de Caldas, MG. 


\subsection{LEVEDURAS}

As leveduras utilizadas foram Saccharomyces cerevisiae de alta fermentação.

O inóculo foi preparado a partir da levedura cervejeira liofilizada comercial Saccharomyces cerevisiae tipo ale da marca Fermentis S-04.

\subsection{TESTES PRELIMINARES}

Com o objetivo de avaliar os açúcares presentes em um mosto de cerveja usando como adjunto café, foram feitas análises em Cromatografia Líquida de Alta Eficiência (HPLC).

\subsubsection{Elaboração dos mostos}

Foram elaborados 3 tipos de mostos:

- Mosto elaborado com $100 \%$ de malte

- Mosto elaborado com 55\% de malte e $45 \%$ de café verde

- Mosto elaborado com $55 \%$ de malte e $45 \%$ de café torrado

A quantidade de $1,76 \mathrm{~kg}$ de malte foram moídas a seco, em moinho de rolos, com distância de 0,7 mm entre os rolos, conforme Tschope (2001). Depois foi feito o processo de mosturação com a mistura de 5,28 L de água, $1,76 \mathrm{~kg}$ de malte e 1,44 kg de café.

O mosto foi submetido a diferentes temperaturas por diferentes períodos de tempo como mostra o gráfico abaixo. 
Figura 2. Mosturação aplicada ao hidrolisado de café e malte.

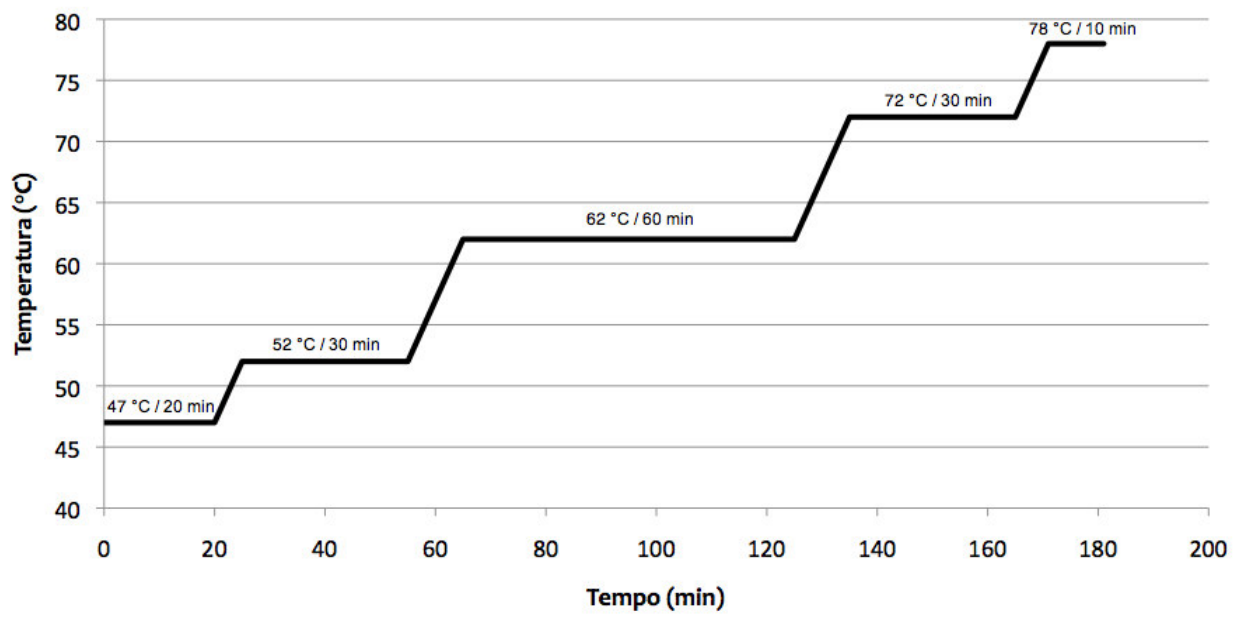

Fonte: Adaptado de Tschope (2001).

Quando a temperatura da mosturação atingiu $72^{\circ} \mathrm{C}$ foi realizado o teste com solução de iodo $0,2 \mathrm{~N}$ a fim de confirmar a sacarificação do amido. Uma amostra do mosto foi coletada e colocada sobre uma superfície branca, e em cima dela foi pingado uma gota de iodo. Confirmada a completa hidrólise do amido com a ausência da coloração roxo- azulada procedeu-se ao aquecimento do mosto a $76^{\circ} \mathrm{C}$ para a inativação das enzimas.

Após o final da mosturação, o mosto foi filtrado, fervido durante uma hora e adicionado os lúpulos Galena e Hallertau Perle. Foram 9,9g do lúpulo Galena e $10 \mathrm{~g}$ de Hallertau Perle.

\subsubsection{Fluxograma do Processo}


Figura 3. Fluxograma do processo usando café como adjunto

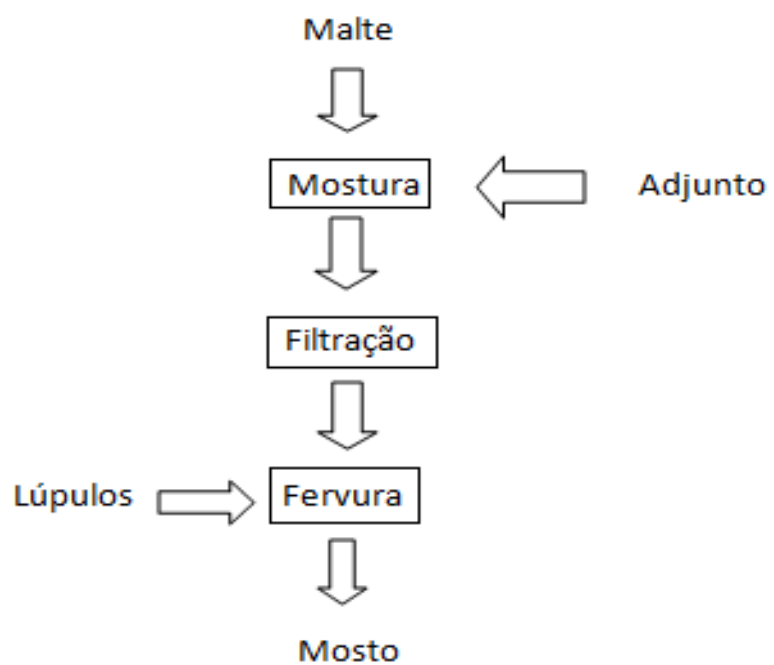

Fonte: Autor

\subsubsection{Análises}

Foram determinadas as concentrações dos açúcares por Cromatografia Líquida de Alta Eficiência (HPLC) em equipamento AGILENT nas seguintes condições: coluna Aminex HPX-87 H (300x7,8 mm), para a fase móvel foi empregado $\mathrm{H}_{2} \mathrm{SO}_{4} \quad 0,01 \mathrm{~N}$ desgaseificado, fluxo de $0,6 \mathrm{~mL} / \mathrm{min}$ a $45^{\circ} \mathrm{C}$.

Antes da determinação por HPLC, as amostras foram centrifugadas a 400xg por $20 \mathrm{~min}$, e os sobrenadantes foram diluídos em água deionizada e passados por filtros 0,45 $\mu \mathrm{m}$ (Millipore) e Sep-Pak $\mathrm{C}_{18}$ Cartridge (Waters Associates).

\subsubsection{Análise Sensorial usando a escala do Ideal}

Foi feita uma análise sensorial usando a escala do ideal para avaliar a intensidade de café na cerveja considerado ideal pelo consumidor.

Os testes foram aplicados no laboratório de Análise Sensorial da EEL que possui ambiente climatizado e cabines individuais. O painel foi composto por 30 consumidores maiores de 18 anos. 
A amostra utilizada durante o teste foi uma cerveja usando $45 \%$ de café como adjunto.

Figura 4. Ficha utilizada para a análise sensorial utilizando a escala do ideal

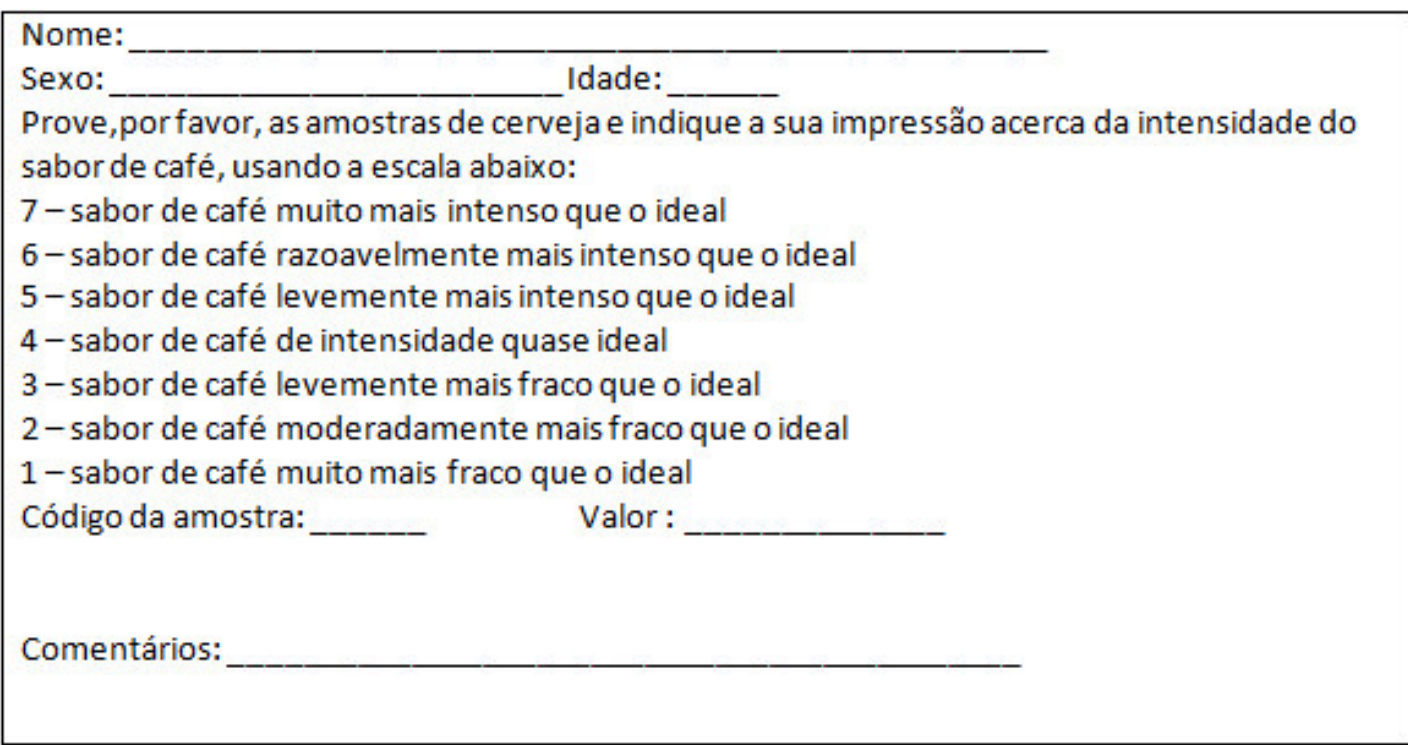

Fonte: Adaptado de Reis; Minim (2013)

\subsection{PRODUÇÃO DE CERVEJA EM ESCALA LABORATORIAL}

Foram elaboradas 5 mostos, sendo 4 aromatizados com café em diferentes proporções e um mosto sem café para ser usada como controle.

Os mostos foram obtidos com os seguintes tratamentos:

Tratamento 1- mosto elaborado com $100 \%$ de malte

Tratamento 2- mosto elaborado com $15 \%$ de café

Tratamento 3 - mosto elaborado com $25 \%$ de café

Tratamento 4 - mosto elaborado com $35 \%$ de café

Tratamento 5 - mosto elaborado com $45 \%$ de café

\subsubsection{Elaboração dos mostos}


Produziu-se 7L de mosto para cada tratamento. A quantidade de $1,76 \mathrm{~kg}$ de malte foi moída em moinho de rolos. Depois foi feito o processo de mosturação com a mistura de 5,28 L de água ao malte moído.

O mosto foi submetido a diferentes temperaturas por diferentes períodos de tempo como mostra a Figura 2.

Após o teste com solução de iodo $0,2 \mathrm{~N}$, e a confirmação da completa sacarificação do amido, aqueceu-se o mosto a $76^{\circ} \mathrm{C}$ para a inativação das enzimas.

$\mathrm{O}$ mosto foi separado do bagaço do malte e transferido para a panela de fervura. $\mathrm{O}$ café torrado e moído foi despejado em cima do bagaço e uma parte da água secundária foi derramada sobre a mistura, assim o café foi filtrado pelo bagaço e gerou-se uma bebida de café.

Ao final da mosturação, o mosto foi fervido durante uma hora. Foram adicionados durante os primeiros $60 \mathrm{~min}$ da fervura, $6 \mathrm{~g}$ do lúpulo Galena e $4 \mathrm{~g}$ desse lúpulo quando faltavam 20 min para acabar a fervura. O amargor desejado com a adição dessa quantidade de lúpulo foi de 36,8 IBU. A bebida de café torrado e moído gerada como explicado acima foi adicionada $10 \mathrm{~min}$ antes de acabar a fervura.

As quantidades de matéria-prima podem ser visualizadas na tabela 4.

Tabela 4. Relações de massa de malte e café utilizados durante o experimento

\begin{tabular}{cccccc}
\hline & T1 & T2 & T3 & T4 & T5 \\
\hline Malte (kg) & 1,76 & 1,76 & 1,76 & 1,76 & 1,76 \\
Café (kg) & 0 & 0,310 & 0,586 & 0,947 & 1,44 \\
\hline
\end{tabular}

T1- mosto elaborado com 100\% de malte; T2 - mosto elaborado com 15\% de café; T3 - mosto elaborado com 25\% de café; T4 - mosto elaborado com 35\% de café; T5 - mosto elaborado com $45 \%$ de café.

Terminada a fervura, o "trub" e o bagaço do lúpulo foram separados. O "trub" é a precipitação de proteínas, polifénois e outros compostos insolúveis.

Posteriormente o mosto foi resfriado e transferido para o fermentador, sendo então inoculado com a levedura cervejeira.

\subsubsection{Fermentações}

Todas as fermentações foram realizadas em fermentadores cilíndricos de $20 \mathrm{~L}$, sem agitação e à uma temperatura de $20^{\circ} \mathrm{C}$ (ideal para fermentações do tipo Ale). Ocorreu em 72 horas. 


\subsubsection{Maturação}

Foi realizado após a fermentação por 14 dias e em baixa temperatura, próxima a 0 ${ }^{\circ} \mathrm{C}$, visando a sedimentação de células e colóides.

\subsubsection{Carbonatação e Envase}

Após a maturação, as bebidas foram engarrafadas em garrafas de vidro ambar de $600 \mathrm{~mL}$, com uma solução concentrada de açúcar em $5 \mathrm{~g} / \mathrm{L}$ para refermentação e carbonatação do produto por 45 dias em temperatura ambiente.

\subsubsection{Fluxograma do processo em escala laboratorial}

A elaboração da cerveja foi realizada de acordo com o fluxograma apresentado abaixo. 
Figura 5. Fluxograma de produção de cerveja.

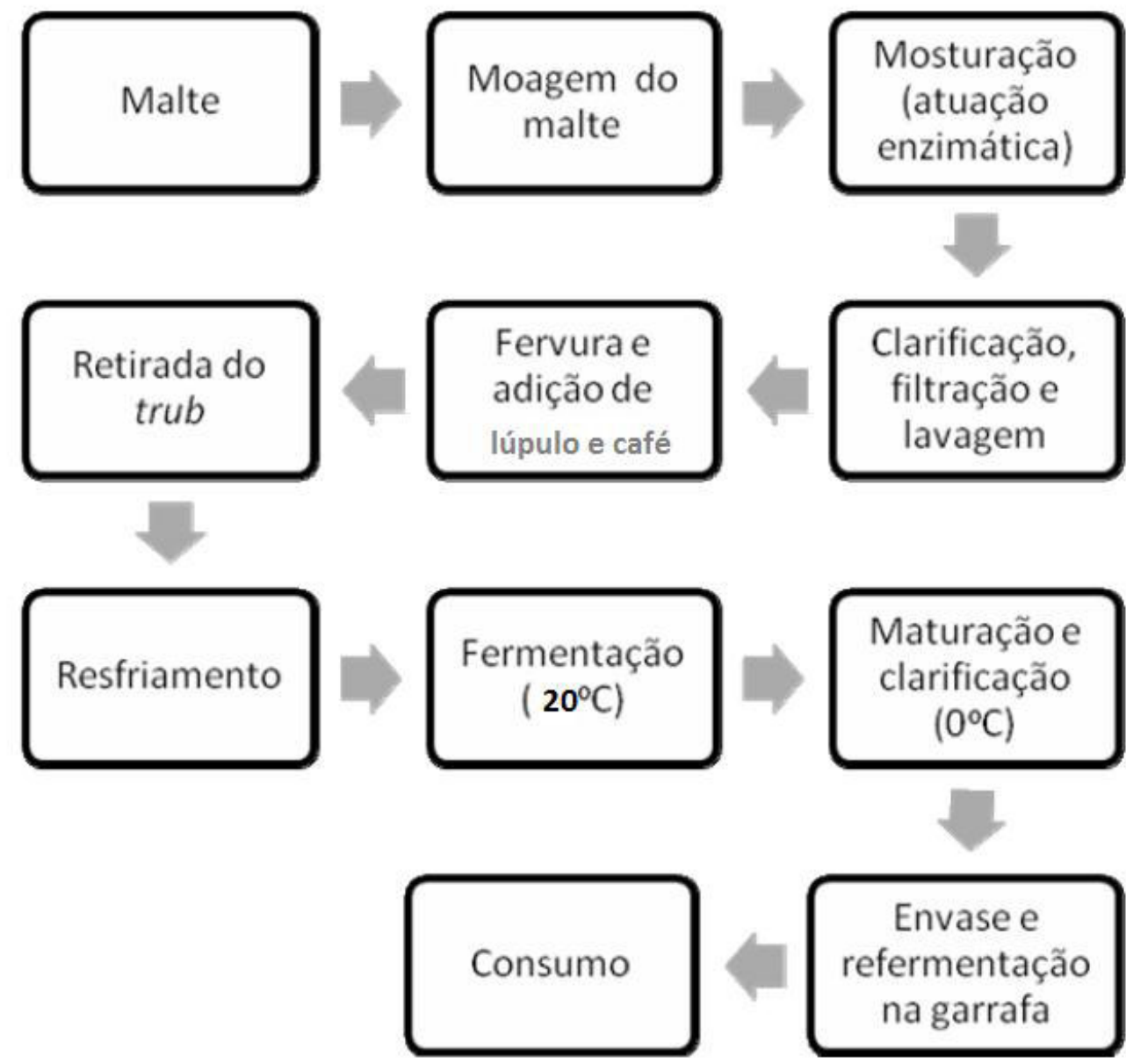

Fonte: Adaptado de Dragone; Almeida e Silva (2010).

\subsection{PRODUÇÃO DE CERVEJA EM ESCALA PILOTO}

Os ensaios em escala piloto foram conduzidos na Planta Piloto de Bebidas da EEL, com capacidade de produção para 200L.

\subsubsection{PREPARO DO MOSTO}

A quantidade de malte utilizados para a obtenção de $80 \mathrm{~L}$ de mosto a $14,21^{\circ} \mathrm{P}$, foi de $19 \mathrm{~kg}$ com uma proporção de café de $45 \%$ respectivamente. 
No tanque de mosturação foram adicionados o malte e 57 litros de água. Todo o sistema foi submetido à mosturação, conforme descrito no item 4.5.1. Ao final da mosturação a $72{ }^{\circ} \mathrm{C}$ foi realizado o teste com solução de iodo a $0,2 \mathrm{~N}$ para verificar a sacarificação do amido do malte. Após a confirmação, a mistura foi aquecida a $76{ }^{\circ} \mathrm{C}$ durante 10 minutos para inativar as enzimas do malte.

\subsubsection{FILTRAÇÃO DO MOSTO}

O mosto foi submetido à filtração em tanque de aço inox com capacidade para 120L contendo agitador, disco filtrante ranhurado Pak Screens, bomba centrífuga e isolamento térmico.

O mosto foi separado do bagaço do malte e transferido para a tina de fervura. Uma quantidade de $15,5 \mathrm{~kg}$ de café torrado e moído foi despejado em cima do bagaço e uma parte da água secundária a $80{ }^{\circ} \mathrm{C}$. foi derramada sobre a mistura, assim o café foi filtrado pelo bagaço e gerou-se uma bebida de café.

\subsubsection{FERVURA DO MOSTO}

O mosto filtrado foi submetido à fervura em tanque de aço inox encamisado, com capacidade para 250L, provido de aquecimento elétrico e isolamento térmico. Durante os 60 minutos de fervura foram adicionados os lúpulos em peletes e o café.

Ao final da mosturação, o mosto foi fervido durante uma hora. Foram adicionados durante os primeiros 60 min da fervura, $65 \mathrm{~g}$ do lúpulo Galena e $56 \mathrm{~g}$ desse lúpulo quando faltavam 20 min para acabar a fervura. O amargor desejado com a adição dessa quantidade de lúpulo foi de 36,8 IBU. A bebida de café torrado e moído gerada como explicado acima foi adicionada 10 min antes de acabar a fervura.

Após a fervura, o mosto foi submetido à recirculação tangencial por cerca de 60 minutos para permitir a precipitação de proteínas e polifenóis. Durante este tempo, o mosto foi resfriado por meio de circulação de água fria no tanque que é encamisado.

Após a recirculação, o mosto foi mantido em repouso por 60 minutos, sendo resfriado a $30{ }^{\circ} \mathrm{C}$. Ao final deste período, foi retirado o sedimento de proteínas e 
polifenóis, denominado "trub", e o mosto transferido por bombeamento para o tanque de fermentação.

Figura 6. Da esquerda para a direita tem-se a tina de mosturação, a tina de filtração e a tina de fervura

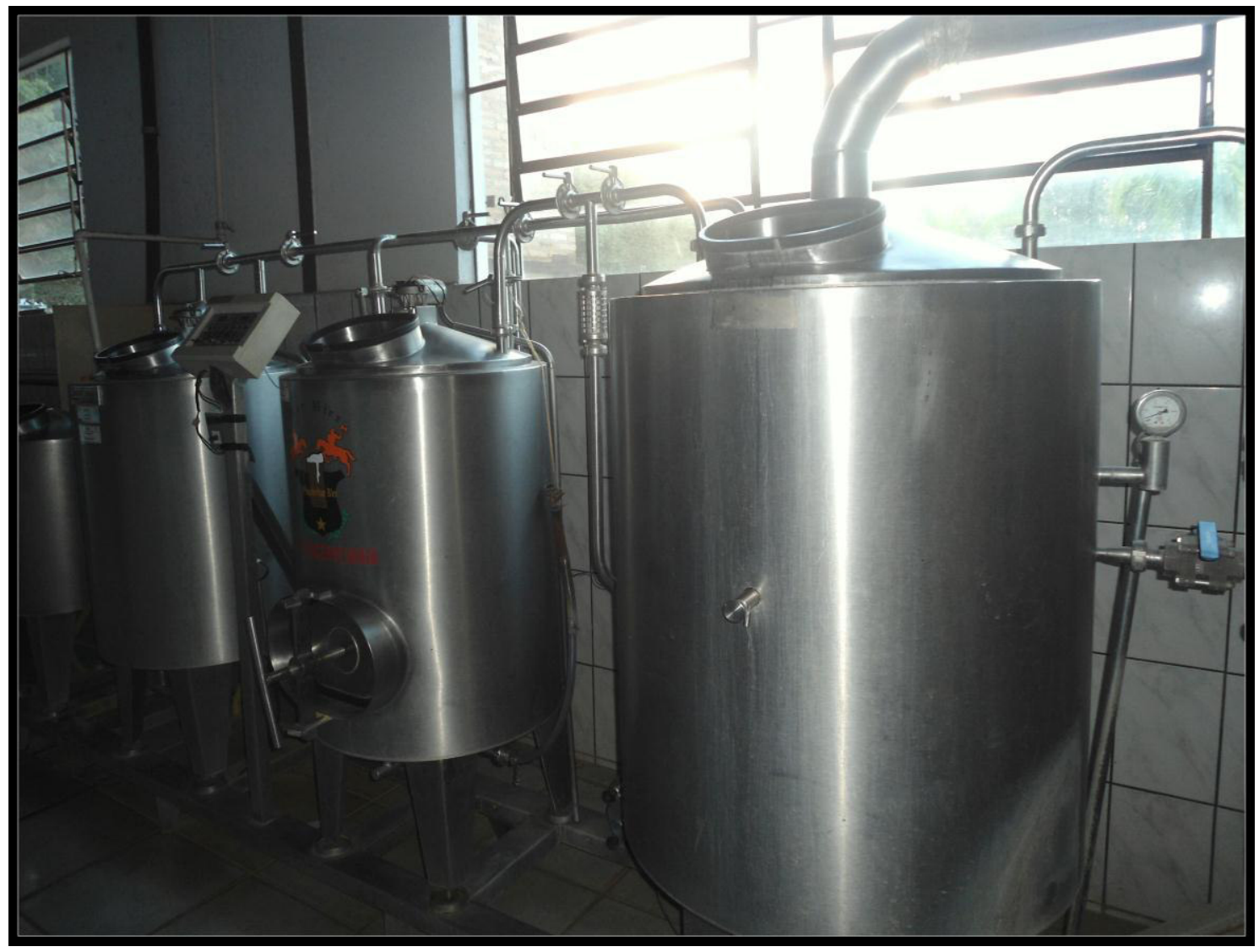

Fonte: Autor

\subsubsection{FERMENTAÇÃO}

As fermentações foram conduzidas em tanque de fermentação com capacidade de 200L, equipado com controlador e indicador digital de temperatura e registro para retirada de amostras.

Após a transferência do mosto para o fermentador, a temperatura foi ajustada a $20^{\circ} \mathrm{C}$, e em seguida foi adicionado o inóculo. Os microrganismos utilizados foram leveduras Saccharomyces cerevisiae de alta fermentação. As fermentações foram conduzidas nas temperaturas de $20^{\circ} \mathrm{C}$. Foram retiradas amostras a cada 12 horas e feitas determinações dos teores de álcool e de extratos por meio do analisador de bebidas Anton 
Paar, modelo Beer Analyzer 2. O ponto final da fermentação foi determinado quando, já não houve variação nas determinações destes teores entre 2 medições consecutivas.

Imediatamente ao constatar o término da fermentação, o excesso de leveduras foi retirado pelo fundo do fermentador e a temperatura ajustada em $0{ }^{\circ} \mathrm{C}$ para o início da maturação, permanecendo assim por 14 dias.

\subsubsection{FILTRAÇÃO}

Ao término da maturação, o chope (cerveja que ainda não sofreu o processo de pasteurização) obtido foi filtrado em filtro prensa com placas de celulose KS-100, com $2 \mathrm{kgf} / \mathrm{cm}^{2}$, utilizando terra diatomácea como adjuvante de filtração. O chope filtrado foi armazenado em tanque e iniciado a carbonatação para correção da pressão em $\mathrm{CO}_{2}$ para 2 $\mathrm{kgf} / \mathrm{cm}^{2}$ e posterior análise sensorial.

\subsubsection{EMBALAGEM E PASTEURIZAÇÃO}

Após a filtração e correção do teor de $\mathrm{CO}_{2}$, o chope foi envasado manualmente em garrafas de vidro de $600 \mathrm{~mL}$ desinfetadas e limpas.

O processo de pasteurização foi conduzido em autoclave com água suficiente para cobrir as garrafas dispostas em pé, deixando de fora apenas a boca da garrafa. O controle de temperatura foi feito com um termômetro digital colocado em uma garrafa com água, destampada. Após a temperatura atingir $63{ }^{\circ} \mathrm{C}$ dentro da garrafa controle, iniciou-se o tempo de contagem da pasteurização, estipulado em 30 minutos.

Após este tempo, as garrafas foram submersas em água a $2{ }^{\circ} \mathrm{C}$, e o controle de temperatura feito com a adição de gelo. As garrafas foram armazenadas em câmara fria a $2{ }^{\circ} \mathrm{C}$ até o momento da análise sensorial.

\subsubsection{FLUXOGRAMA DO PROCESSO EM ESCALA PILOTO}

A elaboração da cerveja foi realizada de acordo com o fluxograma apresentado abaixo. 
Figura 7. Fluxograma de produção de cerveja.

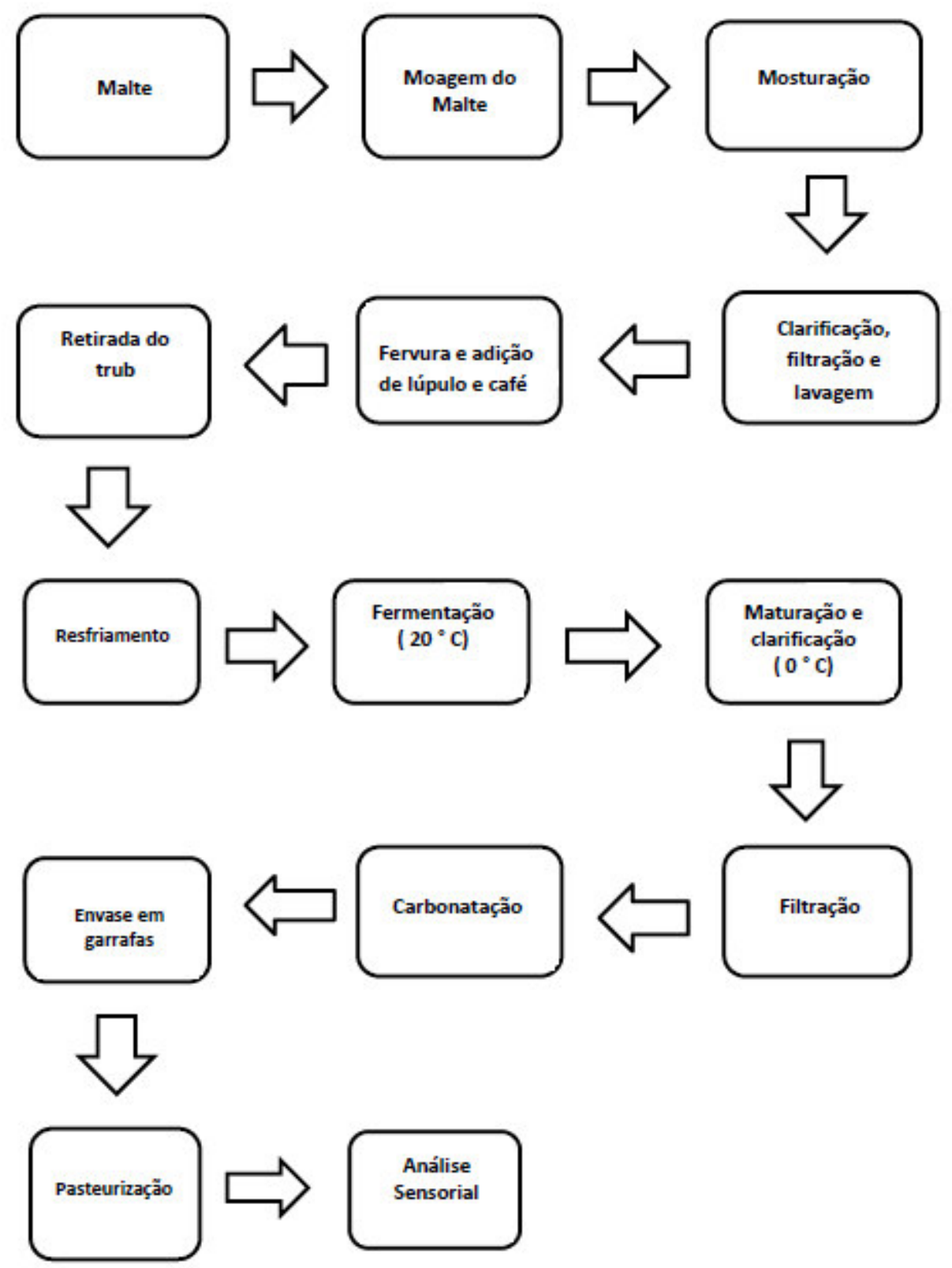

Fonte: Adaptado de Dragone; Almeida e Silva (2010).

\subsection{MÉTODOS ANALÍTICOS}

\subsubsection{ANÁLISES FÍSICO-QUÍMICAS}


Durante o processo de fermentação foram retiradas amostras com $30 \mathrm{~mL}$ de mosto a cada doze horas. Estas amostras foram desgaseificadas pela agitação vigorosa durante 1 min. Para a determinação da concentração de células em suspensão foram utilizados 10 $\mathrm{mL}$ da amostra desgaseificada conforme descrito no item 4.6.3. O sobrenadante obtido após a centrifugação a 4000xg por 20 min, foi utilizado para quantificar a quantidade de extratos, álcool, $\mathrm{pH}$ e densidade do mosto.

\subsubsection{1. $\mathrm{pH}$}

O potencial hidrogeniônico foi medido diretamente em pHmetro digital, da marca Marconi, modelo MA- 522 utilizando-se $15 \mathrm{~mL}$ de amostra.

\subsubsection{Concentração de álcool}

A concentração de álcool da amostra foi determinada em equipamento analisador de cerveja (Beer Analyser 2, ANTON-PAAR) e o resultado expresso em \% v/v.

\subsubsection{Densidade}

A densidade da amostra foi determinada em equipamento analisador de cerveja (Beer Analyser 2, ANTON-PAAR) e o resultado expresso em $\mathrm{g} / \mathrm{cm}^{3}$.

\subsubsection{Determinação de açúcares Totais}

A determinação da concentração aparente de açúcares totais ou extrato aparente durante a fermentação foi realizada em equipamento analisador de cerveja (Beer Analyser 2, ANTON-PAAR) e o resultado expresso em ${ }^{\circ}$ Plato $\left({ }^{\circ} \mathrm{P}\right.$ ou ${ }^{\circ}$ Plato é o peso de extrato ou açúcar, equivalente ao peso de sacarose em $100 \mathrm{~g}$ de uma solução a $20^{\circ} \mathrm{C}$ ).

Para a identificação do tipo e do teor de açúcar, o mosto foi analisado por Cromatografia Líquida de Alta Eficiência (CLAE), utilizando uma coluna Aminex HPX$87 \mathrm{H}(300$ x 7,8 mm, Bio-Rad Laboratories Ltd) em um cromatógrafo da marca AGILENT. Como fase móvel foi empregado $\mathrm{H}_{2} \mathrm{SO}_{4}$ 0,005 mol.L $\mathrm{L}^{-1}$ com fluxo de 0,6 $\mathrm{mL} \cdot \mathrm{min}^{-1}$, a $45^{\circ} \mathrm{C}$. 


\subsubsection{Determinação dos teores de Extratos}

Os teores de extrato original, real e aparente foram determinados em equipamento analisador de cerveja (Beer Analyser 2, ANTON-PAAR) e o resultado expresso em ${ }^{\circ} \mathrm{P}$.

\subsubsection{ANÁLISE DA FERMENTAÇÃO}

Durante a fermentação foram medidos o teor de álcool (\% v/v), o extrato original, o extrato real $(\% \mathrm{~m} / \mathrm{m})$, e o extrato aparente $\left({ }^{\circ} \mathrm{P}\right)$, e determinado o grau aparente de fermentação (\%) e grau real de fermentação (\%), por meio do equipamento Beer Analyzer 2 (Anton Paar).

Ao final da fermentação, o rendimento foi calculado pela equação 1 .

$$
\mathrm{Y} \mathrm{p} / \mathrm{s}=\mathrm{m}_{\mathrm{Et}} / \mathrm{m}_{\mathrm{AC}}
$$

Na qual:

$\mathrm{Y}_{\mathrm{p} / \mathrm{s}}=$ Quantidade de álcool produzido em relação ao açúcar consumido $(\mathrm{g} / \mathrm{g})$;

$\mathrm{m}_{\mathrm{Et}}=$ massa de álcool produzido $(\mathrm{g})$;

$\mathrm{m}_{\mathrm{AC}}=$ massa de extrato consumido $(\mathrm{g})$

A eficiência da fermentação será obtida pela equação 2:

$$
\text { Eficiência }(\%)=\underline{\mathrm{Y}}_{\mathrm{Y} / \mathrm{s} \text { obtidérico }} \times 100
$$

O cálculo da produtividade em álcool foi feito por meio da equação 3:

$$
\mathrm{Q}=\frac{\mathrm{TA}_{\mathrm{f}}-\mathrm{TA}_{\mathrm{i}}}{\mathrm{t}}
$$

$\mathrm{Q}=$ Produtividade em álcool $\left(\mathrm{g} \cdot \mathrm{L}^{-1} \cdot \mathrm{h}^{-1}\right)$

$\mathrm{TA}_{\mathrm{f}}=$ Teor de álcool final $(\mathrm{g} / \mathrm{L})$

$\mathrm{TA}_{\mathrm{i}}=$ Teor de álcool inicial $(\mathrm{g} / \mathrm{L})$

$\mathrm{t}=$ tempo $(\mathrm{h})$ 


\subsubsection{ANÁLISE MICROBIOLÓGICA}

As análises Microbiológicas foram conduzidas em microscópio determinando-se a viabilidade celular. No início e a cada 12 horas, foram realizadas contagens em câmara de Neubauer $\left(11400 \mathrm{~mm}^{2}\right.$ x $\left.1110 \mathrm{~mm}\right)$ e expresso em número de células/mL. As análises de extratos e de álcool também foram realizadas no mesmo período de amostragem.

\subsubsection{ANÁLISE SENSORIAL}

Foram feitas duas análises sensoriais pelo teste de aceitação: uma após a produção de cervejas feitas em escala laboratorial e outra após a produção de uma cerveja feita em escala piloto. A cerveja mais bem aceita na primeira análise sensorial foi usada na segunda sensorial e comparada com uma comercial.

Os testes de Análise Sensorial foram aplicados no Laboratório de Análise Sensorial da Planta Piloto de Bebidas da EEL, equipado com cabines individuais e iluminação adequada.

As amostras da primeira análise sensorial foram avaliadas em relação à cor, aroma, corpo, sabor e impressão global, assim como a intenção de compra de cada amostra. Os provadores registraram suas notas em fichas com escala hedônica de 9 pontos.

As amostras foram servidas em pequenos copos de plástico transparentes e codificadas com três dígitos aleatórios. Foi usado delineamento em blocos completos casualizados.

O painel sensorial foi composto por uma equipe de 50 provadores, não treinados e consumidores de bebida alcoólica. Os provadores registraram suas notas em fichas conforme a Figura 8. 
Figura 8. Ficha de avaliação sensorial

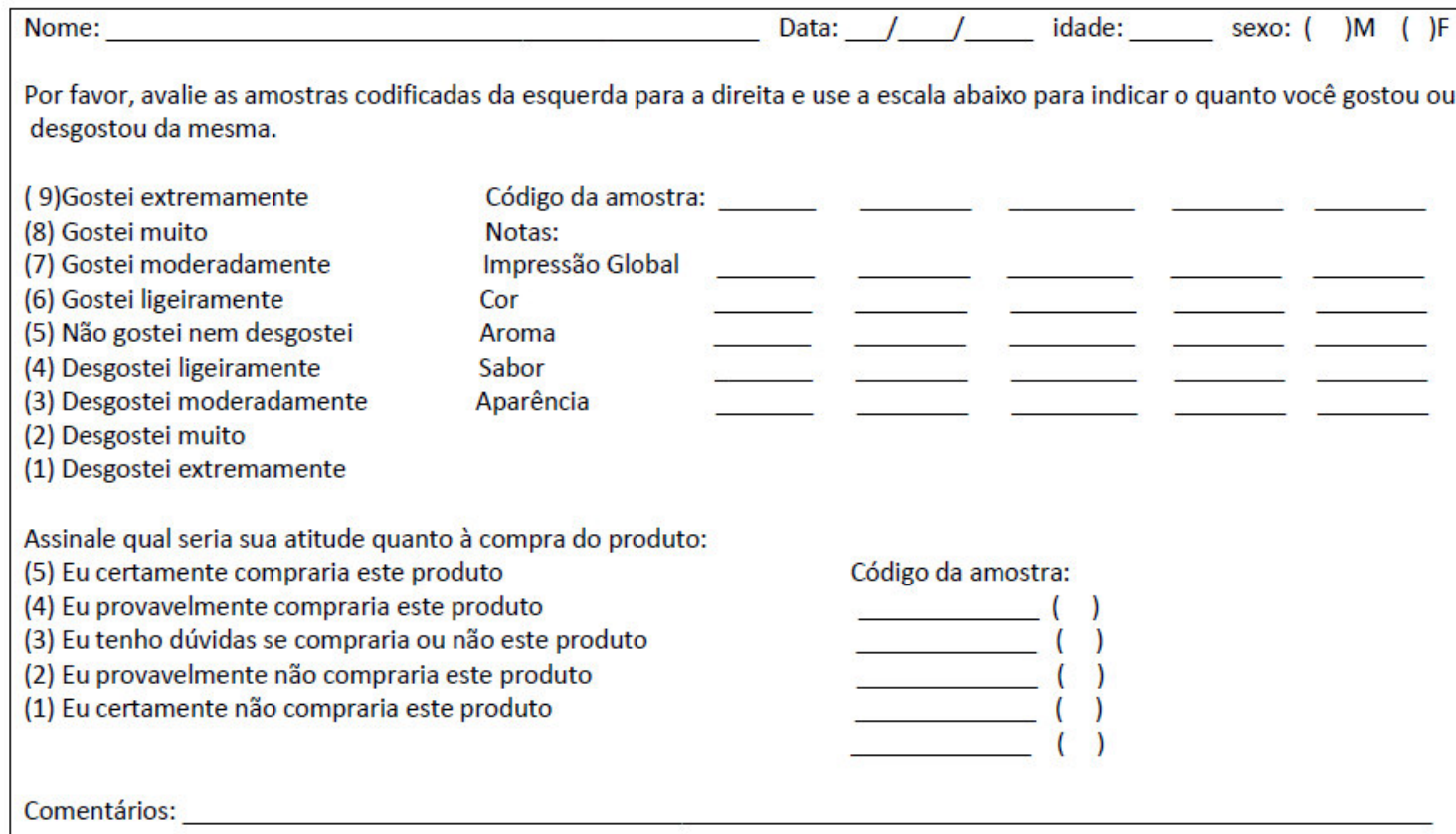

Fonte: Adapatado de Reis; Minim (2013)

As amostras foram servidas em ordem balanceada de apresentação, evitando-se assim resultados tendenciosos conforme a Tabela 5 .

\begin{tabular}{cc} 
Tabela 5. Ordem da apresentação das amostra \\
\hline Provador & $\begin{array}{c}\text { Ordem balanceada de } \\
\text { apresentação das } \\
\text { amostras }\end{array}$ \\
\hline 1 & ABCDE \\
2 & BCDEA \\
3 & CDEAB \\
4 & DEABC \\
Etc... & \\
\hline
\end{tabular}

Fonte: MINIM (2013).

As amostras da segunda análise sensorial foram avaliadas em relação à doçura, aroma, amargor, sabor e impressão global, assim como a intenção de compra de cada amostra.

O painel sensorial foi composto por uma equipe de 59 provadores, não treinados e consumidores de bebida alcoólica. Os provadores registraram suas notas em fichas conforme a Figura 9. 
Figura 9. Ficha de avaliação sensorial

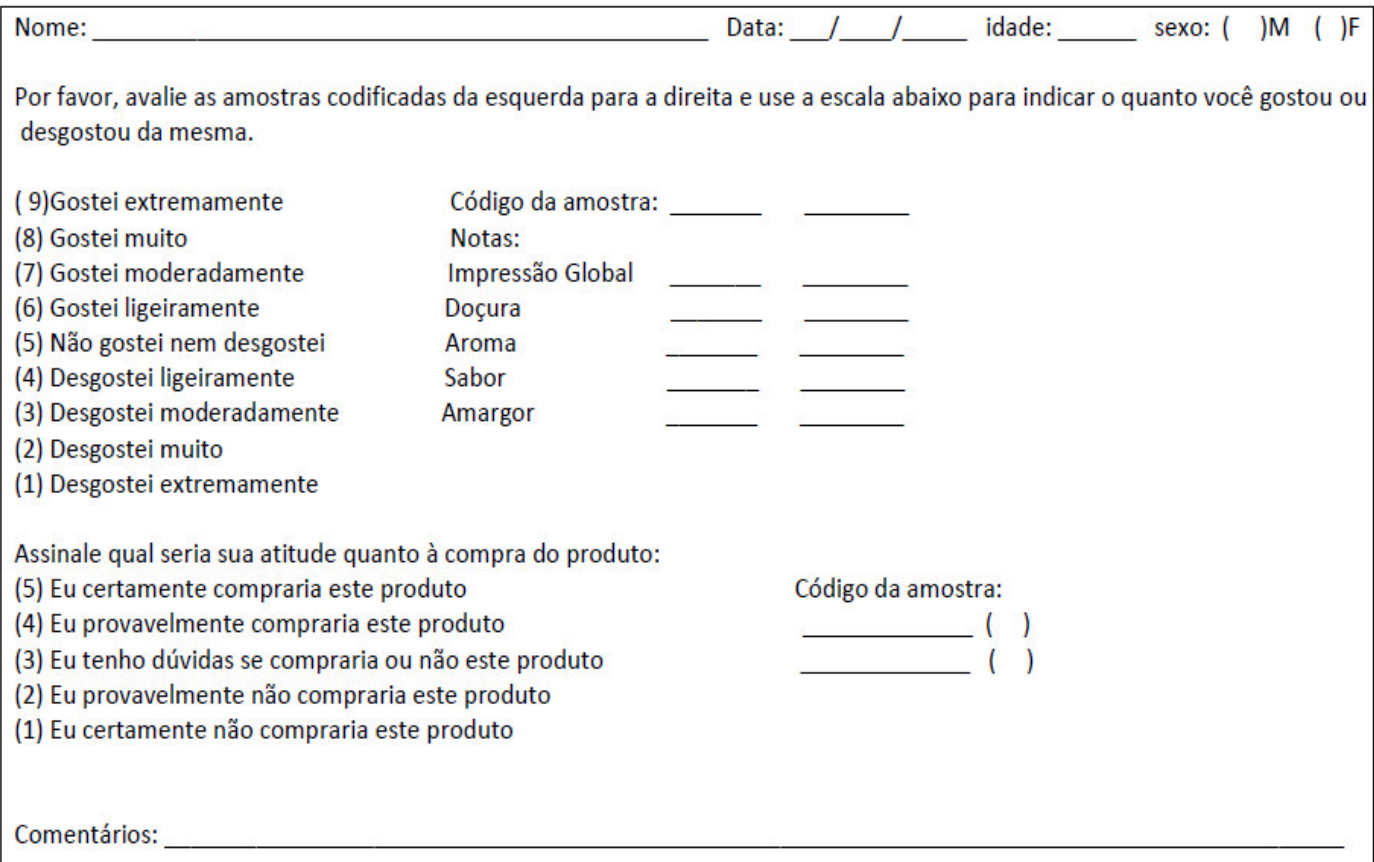

Fonte: Adaptado de Reis; Minim (2013)

As amostras foram servidas em ordem balanceada de apresentação, evitando-se assim resultados tendenciosos conforme a Tabela 6 .

Tabela 6. Ordem da apresentação das amostra

\begin{tabular}{cc}
\hline Provador & $\begin{array}{c}\text { Ordem balanceada de } \\
\text { apresentação das } \\
\text { amostras }\end{array}$ \\
\hline 1 & $\mathrm{AB}$ \\
2 & $\mathrm{BA}$ \\
3 & $\mathrm{AB}$ \\
4 & $\mathrm{BA}$ \\
Etc... & \\
\hline
\end{tabular}

Fonte: Adaptado MINIM (2013).

Após os dados serem coletados, foi realizada a análise de variância e o teste de Tukey para comparação das médias das amostras.

\subsubsection{ANÁLISE ESTATÍSTICA}


Posteriormente a execução dos experimentos, procedeu-se com as análises estatísticas. Os resultados obtidos foram submetidos à análise de variância (ANOVA) e às médias dos tratamentos aplicado o teste de Tukey ao nível de 5\% de significância. Foi usado o programa estatístico MINITAB.

\subsection{ANÁLISE MERCADOLÓGICA}

Antes da segunda análise sensorial, foi realizada uma análise mercadológica através da aplicação de um questionário com 14 perguntas, para mensurar a aceitação do produto: cerveja aromatizada com café.

Os respondentes foram 51 pessoas, maiores de 18 anos e consumidores de bebidas alcoólicas. O apêndice A representa o questionário aplicado. 


\section{RESULTADOS E DISCUSSÃO}

\subsection{TESTES PRELIMINARES}

Com o objetivo de obter algumas informações básicas para a composição da metodologia a ser seguida neste projeto, foram realizados alguns testes preliminares. Os experimentos realizados foram embasados na metodologia de preparação da cerveja tradicional.

\subsubsection{Análise do mosto por cromatografia}

Os resultados apresentados primeiramente são referentes às análises feitas por cromatografia. As análises foram realizadas em amostras do mosto puro malte, com café verde e com café torrado antes da fermentação das bebidas.

O mosto preparado para obtenção da bebida feita com café verde não apresentou sacarificação do amido, comprovado pelo teste de Iodo. Por isso, os resultados mostrados neste trabalho são aqueles obtidos com as amostras de cervejas de mosto puro malte e com $45 \%$ de café torrado.

Foram determinados as concentrações dos açúcares por Cromatografia Líquida de Alta Eficiência (HPLC), os resultados podem ser visualizados na Tabela 7.

Tabela 7. Teores de compostos dos mostos, resultantes da análise cromatográfica

\begin{tabular}{lcc}
\hline \multicolumn{1}{c}{ Constituintes } & Puro malte $(\mathbf{g} / \mathbf{L})$ & Café torrado $(\mathbf{g} / \mathbf{L})$ \\
\hline Celobiose & 0 & 0 \\
Glicose & 10,9 & 11,80 \\
Xilose & 0 & 2,24 \\
Arabinose & 0,07 & 2,58 \\
Xilitol & 0,135 & 0,535 \\
Glicerol & 0,735 & 0,94 \\
Ácido Fórmico & 0,11 & 0,355 \\
Ácido Acético & 0,69 & 1,13 \\
\hline
\end{tabular}

Observa-se que a concentração de glicose tanto no mosto puro malte como no mosto com $45 \%$ de café estão muito próximos. Este açúcar sempre está presente no mosto cervejeiro, porém em concentrações bem inferiores a maltose e maltotriose. 
Andrade (2007) obteve 17,28 g/L de glicose para um mosto usando 35\% de arroz preto como adjunto, além de $63,47 \mathrm{~g} / \mathrm{L}$ e $24,3 \mathrm{~g} / \mathrm{L}$ de maltose e maltotriose respectivamente.

\subsubsection{Análise Sensorial usando a escala do ideal}

Pela análise sensorial usando a escala do ideal foi possível avaliar a intensidade de café na cerveja considerada ideal pelo consumidor. A porcentagem das respostas dos consumidores para cada categoria está apresentada na Tabela 8.

Tabela 8. Porcentagem das respostas dos consumidores em cada categoria

\begin{tabular}{cc}
\hline Categoria & $\begin{array}{c}\text { \% das respostas da cerveja preparada com } \\
45 \% \text { de café }\end{array}$ \\
\hline 7 & 57 \\
6 & 40 \\
5 & 0 \\
4 & 3 \\
3 & 0 \\
2 & 0 \\
1 & 0 \\
\hline
\end{tabular}

Sendo a categoria 7: sabor de café muito mais intenso que o ideal, categoria 6: sabor de café razoavelmente mais intenso que o ideal e categoria 4: sabor de café de intensidade quase ideal. 
Figura 10. Porcentagem das respostas dos consumidores em cada categoria

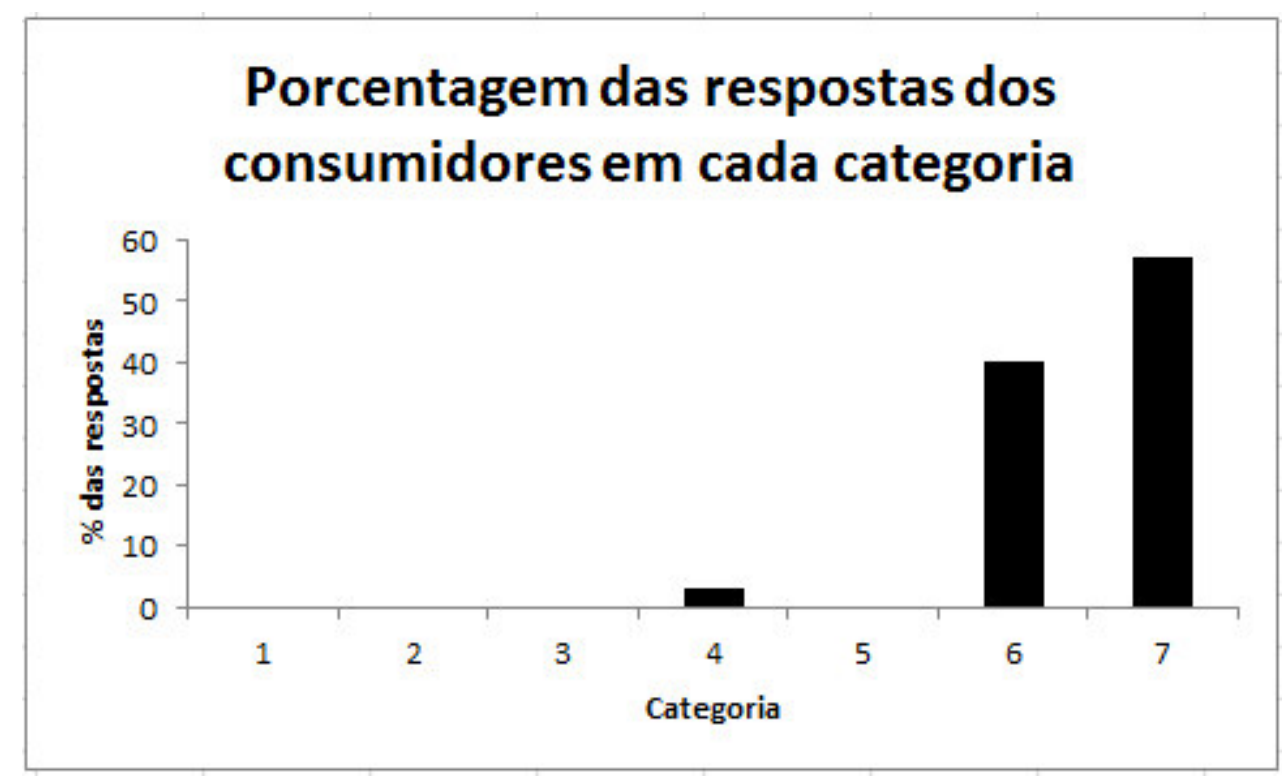

Fonte: Autor

Observa-se que $57 \%$ dos julgadores consideraram o sabor de café muito mais intenso que o ideal e apenas 3\% consideraram o sabor de café de intensidade quase ideal, portanto a cerveja com $45 \%$ de café deve ser reformulada diminuindo-se a concentração de café.

Por isso, as pesquisas ao prosseguiram com a produção de cervejas com diferentes concentrações de café $(45 \%, 35 \%, 25 \%, 15 \%$ e $0 \%)$. Foi também utilizado o café como aromatizante sendo adicionado na etapa da fervura, porque pelo resultado obtido quanto ao teor de carboidratos este não poderia ser denominado como adjunto.

\subsection{ANÁLISES DE pH DOS MOSTOS DAS CERVEJAS}

Foi realizada a análise de $\mathrm{pH}$ dos mostos com diferentes concentrações de café, e os resultados obtidos podem ser visualizados na Tabela 9.

Tabela 9. Médias de $\mathrm{pH}$ dos mostos com diferentes proporções de café

\begin{tabular}{lllllll}
\hline Análise & T1 & T2 & T3 & T4 & T5 & CP \\
\hline pH & 6,1 & 5,8 & 5,8 & 5,6 & 5,7 & 5,8 \\
\hline
\end{tabular}

T1- mosto elaborado com 100\% de malte; T2 - mosto elaborado com 15\% de café; T3 - mosto elaborado com $25 \%$ de café; T4 - mosto elaborado com $35 \%$ de café; T5 - mosto elaborado com $45 \%$ de café; CPCerveja com $45 \%$ de café produzida em escala piloto 
Observa-se na Tabela 9 que o pH variou entre 5,6 e 6,1 e que é independente da variação da concentração de café, valores estes de acordo com os resultados de pH de mostos sugeridos por Meilgaard (2002) entre 5,0 e 6,0.

De acordo com Ros (1980) a composição dos sais dissolvidos em água usada na fabricação da cerveja tem influência direta sobre o $\mathrm{pH}$ do mosto da cerveja. $\mathrm{O} \mathrm{pH}$ adequado está entre 5,0 e 6,0. Um pH muito elevado pode comprometer a ação das enzimas na sacarificação do amido além de se tornar propício para o desenvolvimento de microrganismos indesejáveis, afetando a qualidade da cerveja, além de prejudicar clarificação da cerveja. Na página 27 deste presente estudo, percebemos pela Tabela 2 que a água da cervejaria está com o pH apropriado para a produção das cervejas, o pH é 6,6 .

$\mathrm{O}$ pH do mosto elaborado sem café, identificado como tratamento 1, obteve valor ligeiramente maior quando comparado com os outros mostos. Estes mostos podem ter sofrido influência na alteração de pH devido ao teor de café na formulação, já que a bebida café é um alimento considerado ácido. Segundo Sivetz e Derosier (1979), o café tem valores de $\mathrm{pH}$ compreendidos entre 4,9 e 5,1.

Portanto, tal comportamento sugere que o uso do café como aromatizante na elaboração do mosto cervejeiro não irá comprometer a ação das enzimas, pelo menos quanto aos valores obtidos de $\mathrm{pH}$.

\subsection{ANÁLISES FISICO-QUIMICAS DAS CERVEJAS EM ESCALA LABORATORIAL}

As cervejas obtidas com diferentes concentrações de café foram analisadas no analisador de bebidas Anton Paar, modelo Beer Analyzer 2, e os resultados são apresentados na Tabela 10. 
Tabela 10. Composição das cervejas obtidas com diferentes concentrações de café

\begin{tabular}{lccccc}
\hline \multicolumn{1}{c}{ Análises } & T1 & T2 & T3 & T4 & T5 \\
\hline $\begin{array}{l}\text { Extrato Real } \\
(\% \mathbf{m} / \mathbf{m})\end{array}$ & 5,27 & 4,55 & 5,10 & 4,50 & 6,02 \\
$\begin{array}{l}\text { Extrato Aparente } \\
\left({ }^{\circ} \mathbf{P}\right)\end{array}$ & 3,30 & 2,82 & 3,27 & 2,59 & 4,09 \\
$\begin{array}{l}\text { Extrato Original } \\
\left({ }^{\circ} \mathbf{P}\right)\end{array}$ & 13,92 & 12,41 & 13,41 & 12,90 & 14,50 \\
$\begin{array}{l}\text { Grau Real de } \\
\begin{array}{l}\text { Fermentação }(\%) \\
\text { Grau Aparente de }\end{array}\end{array}$ & 63,89 & 64,50 & 63,18 & 66,67 & 60,34 \\
$\begin{array}{l}\text { Fermentação }(\%) \\
\text { Álcool (\%v/v) }\end{array}$ & 51,79 & 79,90 & 75,47 & 77,25 & 76,29 \\
\hline
\end{tabular}

T1- mosto elaborado com 100\% de malte; T2 - mosto elaborado com 15\% de café; T3 - mosto elaborado com $25 \%$ de café; T4 - mosto elaborado com 35\% de café; T5 - mosto elaborado com $45 \%$ de café.

Observa-se que as concentrações de extrato real e de extrato aparente variam muito pouco, mas também independem da concentração de café, sugerindo que o café não interfere no processo de fermentação. Da mesma forma, a concentração de extrato original, valor estimado para a concentração de extrato no início da fermentação com base nas composições da cerveja, que também apresenta pequenas variações, independente da concentração de café no mosto.

Alguns valores de Extrato Aparente apresentados na tabela se situam dentro da faixa citada por Compton (1978), entre 2,0 a 3,1 ${ }^{\circ} \mathrm{P}$, especificamente as cervejas identificadas com os tratamentos $\mathrm{T} 2$ e T4. As demais cervejas obtiveram valores acima da especificação citada. Já os valores de Extrato Real se situam fora da faixa citada por Compton (1978) que é de 3,7 a 4,8\%, para as cervejas identificadas com os tratamentos T1, T3 e T5 que ficaram acima da faixa mencionada pelo autor. Porém as cervejas identificadas com os tratamentos T2 e T4 estão dentro da faixa citada pelo autor. Segundo Cury (2006) baixos valores de extrato real indicam baixa fermentabilidade dos mostos.

O teor alcóolico das cervejas ficaram entre 5,17 e 5,78 \% v/v. De acordo com Brasil (2009) quando o álcool de uma cerveja se apresentar na faixa entre 4,5-7,0 \%, a bebida é caracterizada como cerveja de alto teor alcoólico. Portanto pode-se inferir neste trabalho que as cervejas produzidas com café são de alto teor alcoólico.

O grau de fermentabilidade Real ficou entre 60,34 a 66,67\% acima dos valores obtidos por Curi (2006) que obteve graus de fermentação reais entre 59,72 e 62,50\%. O que demonstra que a concentração de café não interferiu no processo fermentativo. Isto 
pode ser confirmado pelos resultados obtidos e apresentados na Tabela 11, que mostra os parâmetros fermentativos dos processos.

Para avaliar a eficiência da formação de álcool, as concentrações alcoólicas foram convertidas de v/v em m/v com o auxilio da Tabela de Goldiner et al. (1966).

Tabela 11. Parâmetros Fermentativos obtidos no processo de obtenção de cerveja com diferentes concentrações de café, com 72 hrs de fermentação.

\begin{tabular}{lccccc}
\hline $\begin{array}{c}\text { Parâmetro } \\
\text { Fermentativo }\end{array}$ & T1 & T2 & T3 & T4 & T5 \\
\hline $\begin{array}{l}\text { Rendimento } \\
\left(\mathbf{Y}_{\mathbf{p} / \mathbf{s}}\right)(\mathbf{g} / \mathbf{g})\end{array}$ & 0,48 & 0,50 & 0,49 & 0,50 & 0,50 \\
$\begin{array}{l}\text { Produtividade } \\
\text { em álcool }\end{array}$ & 0,633 & 0,566 & 0,601 & 0,610 & 0,625 \\
$\begin{array}{l}\left(\mathbf{g} . \mathbf{L}^{-\mathbf{1}} \cdot \mathbf{h}^{-\mathbf{1}}\right) \\
\begin{array}{l}\text { Eficiência de } \\
\text { fermentação } \\
(\%)\end{array}\end{array}$ & 93,9 & 97,8 & 95,8 & 97,8 & 97,8 \\
\hline
\end{tabular}

T1- mosto elaborado com 100\% de malte; T2 - mosto elaborado com 15\% de café; T3 - mosto elaborado com $25 \%$ de café; T4 - mosto elaborado com $35 \%$ de café; T5 - mosto elaborado com $45 \%$ de café

De acordo com a Tabela 11 percebe-se valores altos para a produtividade em álcool comparado com outros trabalhos. Carvalho (2009) quando estudou os parâmetros cinéticos de uma cerveja usando banana como adjunto e aromatizante, encontrou valores de produtividade entre 0,25 e $0,58 \mathrm{~g} / \mathrm{L} \cdot \mathrm{h}$, sendo que o maior valor foi obtido quando o mosto foi fermentado na temperatura máxima para uma cerveja tipo Lager, a $15^{\circ} \mathrm{C}$, por 70 horas e com uma concentração inicial de $12^{\circ} \mathrm{P}$.

Portanto pode-se notar que temperaturas mais altas, como $20^{\circ} \mathrm{C}$, utilizada neste trabalho, pode favorecer a produtividade volumétrica em álcool. Dragone et al. (2003) observaram que mostos cervejeiros quando fermentados entre 10 e $15^{\circ} \mathrm{C}$, apresentaram um aumento da produtividade em álcool correspondente ao aumento de temperatura e encontraram como valores respectivamente 0,22 e 0,69 g/L.h. para um mosto com $20^{\circ} \mathrm{P}$.

Os valores dos rendimentos estão próximos do $\left(\mathrm{Y}_{\mathrm{p} / \mathrm{s}}\right)$ téorico estimado por GayLussac $\left(\mathrm{Y}_{\mathrm{p} / \mathrm{s}}=0,511 \mathrm{~g} / \mathrm{g}\right)$, porém ligeiramente maiores que o fator de Balling. Segundo Kristiansen (2007), Balling realizou vários estudos com diferentes tipos de mostos e concluiu que 2,0665g de açúcar geram 1L de etanol, 0,9565g de $\mathrm{CO}_{2}$ e $0,11 \mathrm{~g}$ de levedura na base seca. Isto corresponde a um fator de rendimento de 0,4839 g/g. Carvalho (2009) também encontrou valores altos de rendimento estudando sua cerveja, valores entre 0,42 e $0,48 \mathrm{~g} / \mathrm{g}$. 
Na mesma Tabela 11, podem ser observados os valores da eficiência do processo de obtenção de cerveja com diferentes concentrações de café. Nota-se também ótimos valores para as cervejas produzidas com café, que foram superiores ao valor obtido com a cerveja puro malte que teve $93,9 \%$ de eficiência.

Almeida et al. (2001) avaliaram os parâmetros fermentativos de um mosto altamente concentrado e encontraram como maior valor $87,38 \%$ de eficiência de fermentação em um mosto a $15^{\circ} \mathrm{P}$, fermentando a $25^{\circ} \mathrm{C}$ e com um pH inicial de 5,5.

Portanto pode-se perceber que os valores de fatores de rendimento encontrados neste trabalho foram ótimos, o que reforça a tese de que a presença do café não interfere no processo fermentativo.

As Figuras 11 a 15 mostram os perfis das fermentações para as cervejas obtidas com diferentes concentrações de café.

Figura 11. Perfil da fermentação para a cerveja com $45 \%$ de café identificada como

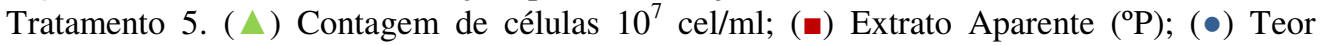
alcoólico $(\% \mathrm{v} / \mathrm{v})$.

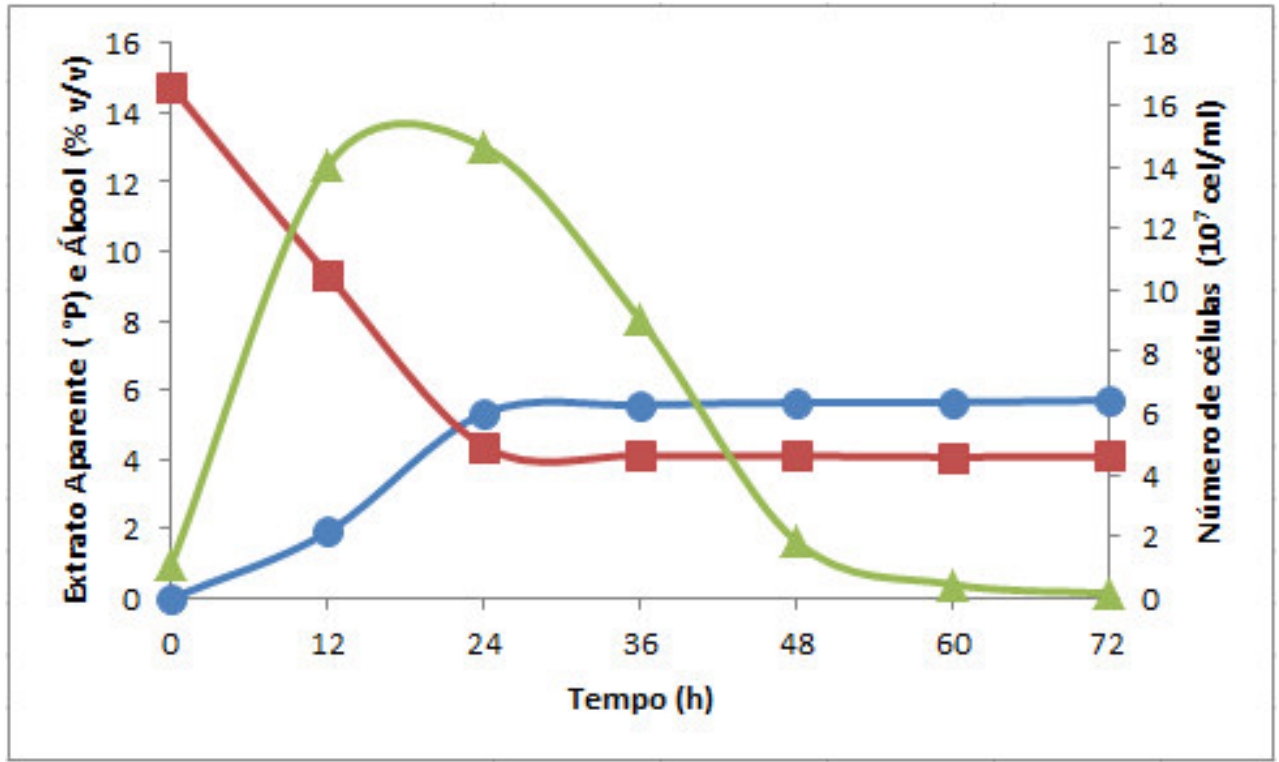

Fonte: Autor

Observa-se na Figura 11, que a cerveja produzida com $45 \%$ de café teve rápida queda da concentração de extrato aparente, decaindo de $14,76^{\circ} \mathrm{P}$ a $4,39{ }^{\circ} \mathrm{P}$, enquanto a produção de álcool atingiu 5,33\%v/v em apenas 24 horas e praticamente se manteve no mesmo nível até 72 horas de fermentação. 
A concentração celular também inicia o decaimento após 24 horas e atinge níveis bem baixos em 60 horas, sugerindo que as leveduras estão floculando devido ao esgotamento dos açúcares fermentescíveis do meio.

Figura 12. Perfil da fermentação para a cerveja com $35 \%$ de café identificada como

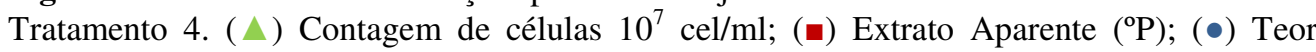
alcoólico $(\% \mathrm{v} / \mathrm{v})$.

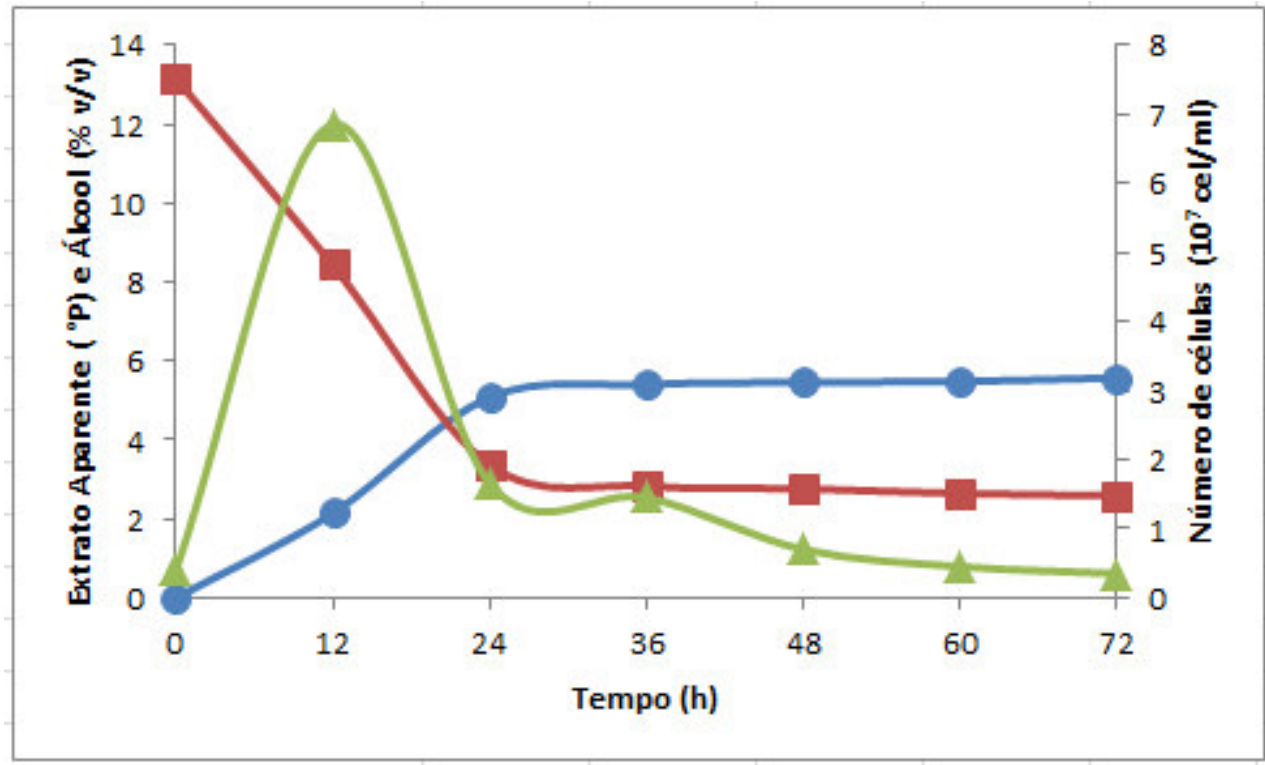

Fonte: Autor

Na Figura 12, assim como ocorreu na Figura 11, a cerveja produzida com $35 \%$ de café teve queda da produção de extrato aparente de $13,15^{\circ} \mathrm{P}$ para 3,36 ${ }^{\circ} \mathrm{P}$ em apenas 24 hrs. E uma produção de álcool de 5,08 em apenas 1 dia.

A concentração celular atinge em 12 horas, uma alta concentração, $6,85 \times 10^{7} \mathrm{cel} / \mathrm{ml}$ e depois se estabiliza a partir de $60 \mathrm{hrs}$ de fermentação. 
Figura 13. Perfil da fermentação para a cerveja com $25 \%$ de café identificada como

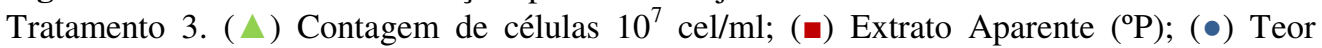
alcoólico (\% v/v).

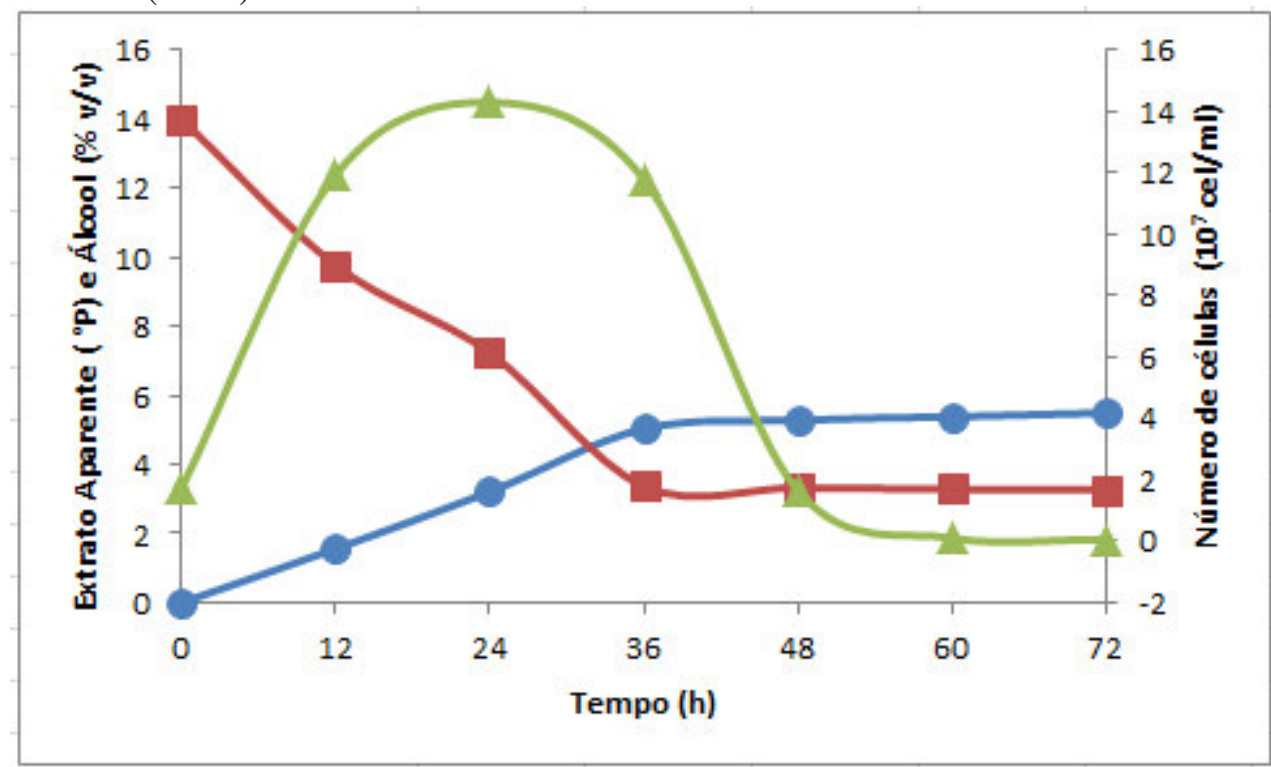

Fonte: Autor

Na Figura 13 percebe-se uma queda da concentração de extrato de 14 ${ }^{\circ} \mathrm{P}$ para $3,37^{\circ} \mathrm{P}$ em 36 horas, e uma produção de álcool de 5,03 \% v/v.

E como aconteceu com as outras cervejas, a cerveja com $25 \%$ de café inicia o decaimento da concentração celular também após 24 horas.

Figura 14. Perfil da fermentação para a cerveja com $15 \%$ de café identificada como

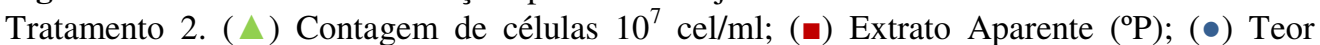
alcoólico (\% v/v).

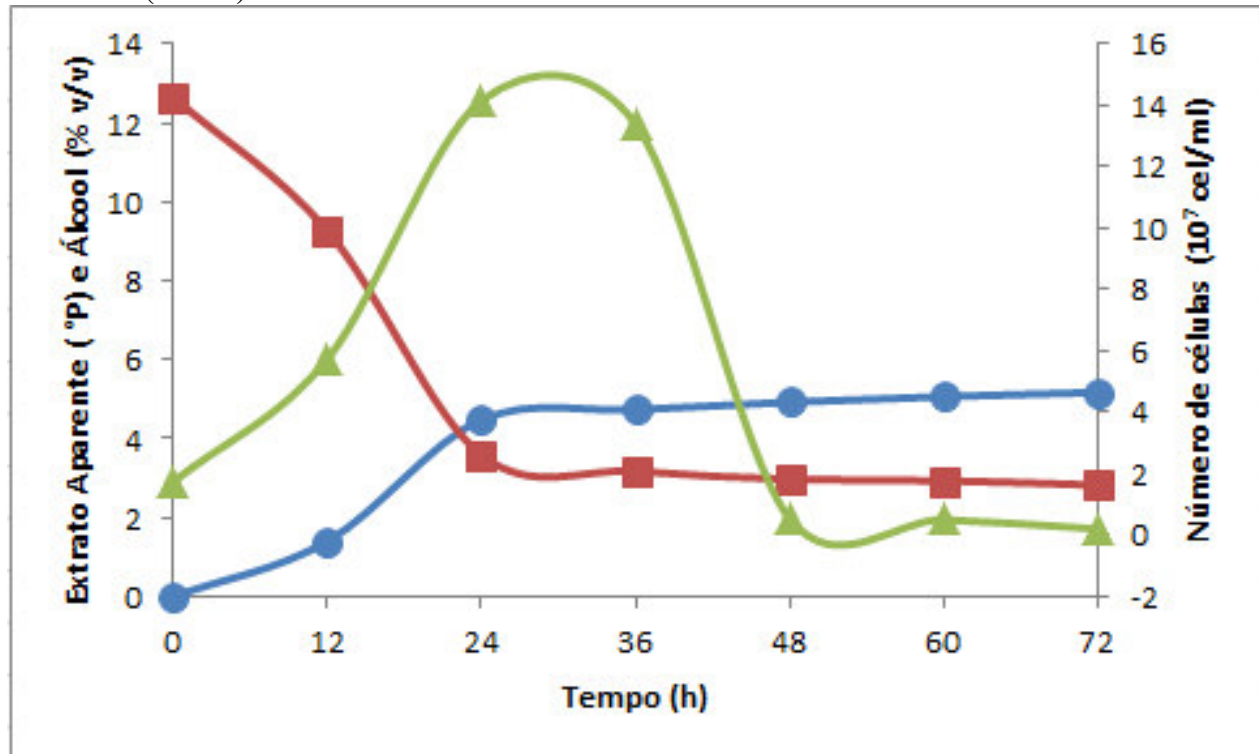

Fonte: Autor 
Com a redução da porcentagem do mosto para 15\% (Figura 14) verifica-se uma queda da concentração de extrato de $12,64^{\circ} \mathrm{P}$ para $3,58{ }^{\circ} \mathrm{P}$ em 24 horas, e uma produção rápida de álcool para o valor de 4,48 \%v/v em apenas um dia.

Quanto à concentração celular, nota-se nessa Figura 14 a máxima concentração em 30 horas após o começo da fermentação, e as células floculam com 48 horas.

Figura 15. Perfil da fermentação para a cerveja com $0 \%$ de café identificada como Tratamento 1. ( $\triangle$ ) Contagem de células $10^{7} \mathrm{cel} / \mathrm{ml}$; (®) Extrato Aparente $\left({ }^{\circ} \mathrm{P}\right) ;(\bullet)$ Teor alcoólico (\% v/v).

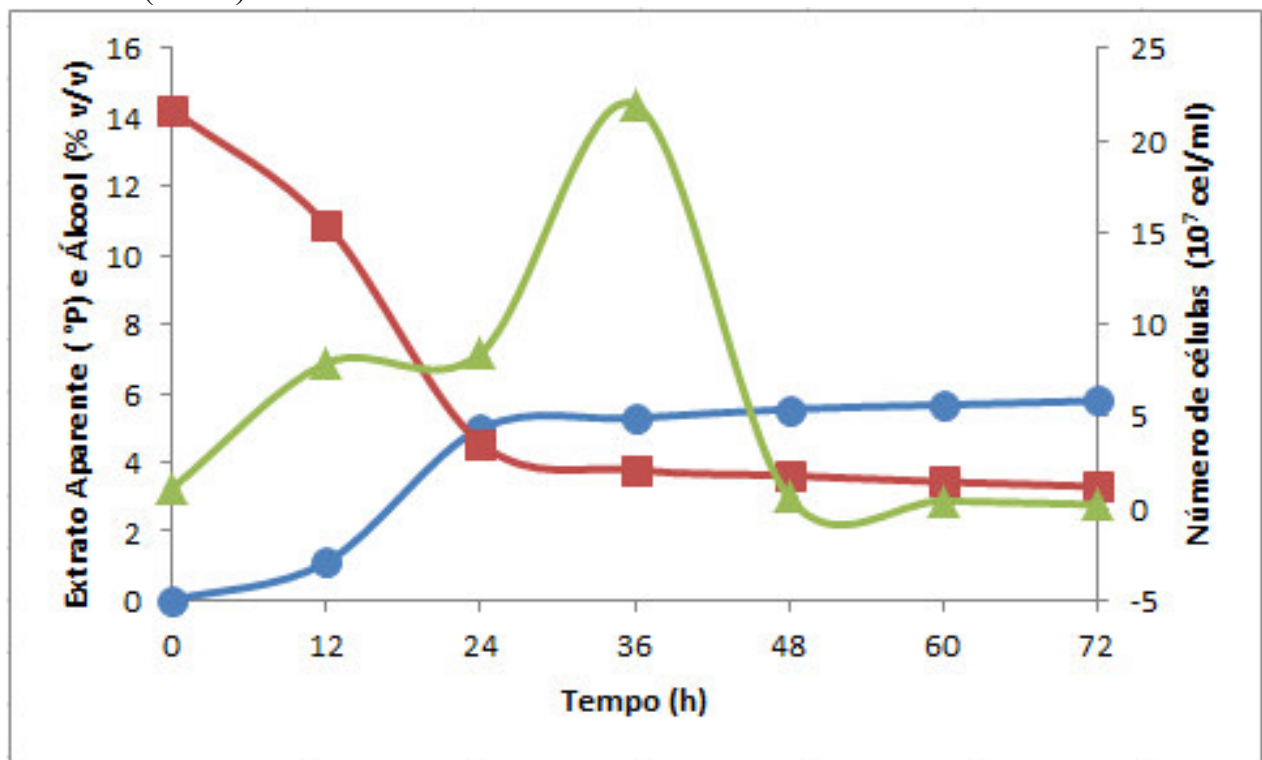

Fonte: Autor

Na Figura 15, a cerveja produzida sem café, ou seja a puro malte, teve decaimento do extrato aparente rapidamente com 24 horas após o início da fermentação, de $14,22{ }^{\circ} \mathrm{P}$ para $4,55^{\circ} \mathrm{P}$, e uma produção de álcool de 4,98 \%v/v, enquanto a concentração celular máxima, $21,95 \times 10^{7} \mathrm{cel} / \mathrm{ml}$, foi atingida 36 horas depois, e atingiu níveis bem baixos em 48 horas.

Pelos gráficos apresentados anteriormente, nota-se que as cervejas do tipo Ale fermentam mais rápido que as cervejas Lager. A fermentação da cerveja do tipo Ale durou de 3 a 5 dias. Isso é devido ao fato das leveduras quando em temperaturas acima de $15^{\circ} \mathrm{C}$ possuírem metabolismo mais rápido comparadas com aquelas em temperaturas inferiores a $12{ }^{\circ} \mathrm{C}$.

Martínez (2014) em um estudo para obter cervejas super concentradas com a utilização de xarope de milho como adjunto do malte, produziu cervejas do tipo Lager 
que fermentaram em 8 a 9 dias. A fermentação do tipo Lager fermentam entre 5 a 8 dias, e isto é devido a temperatura desse tipo de cerveja ser inferior a temperatura de fermentação da cerveja tipo Ale.

Nota-se nas Figuras 11 a 15 que todas as cervejas apresentaram perfis de teores alcoólicos parecidos, alcançaram acima de $5 \%$ v/v. Segundo Sohrabvandi et al. (2010) as cervejas com teor considerado ideal de álcool, possuem aproximadamente $5 \%$ em volume.

Os teores alcoólicos encontrados nas cervejas foi de 5,17 a 5,78, e já eram esperados porque a fermentação começou com um extrato original em torno de $14{ }^{\circ} \mathrm{P}$.

Comparando as Figuras 11 a 15 observa-se que os perfis de consumo de extrato, durante a fermentação, apresentaram comportamentos semelhantes, observando-se que o término das fermentações ocorreram no momento em que as concentrações de extrato aparente ficaram entre 2,6 a 4,0 .

Percebe-se também a relação entre o crescimento celular e a produção de álcool durante a fermentação.

Em todos os gráficos observamos todas as fases de crescimento das leveduras: log, estacionária e declínio. A fermentação não apresenta fase lag, e isso é um indicativo bom, já que essa fase geralmente apenas é observada quando o inóculo inicial não está ambientado totalmente ao meio.

Constata-se que o número máximo de células em suspensão, na maioria dos gráficos é alcançada entre 24 a 36 horas. Apenas na Figura 12 ( 35\% de café) mostra o número máximo de células sendo atingido no tempo de 12 a 13 horas, para a cerveja identificada como T4, cerveja com $35 \%$ de café.

\subsection{ANÁLISE SENSORIAL DAS CERVEJAS EM ESCALA LABORATORIAL}

As bebidas produzidas em escala laboratorial foram avaliadas sensorialmente por 50 provadores não treinados, com a faixa etária entre 18 a 52 anos, sendo $34 \%$ mulheres e $66 \%$ homens. A Figura 16 mostra a porcentagem de provadores para cada gênero. 
Figura 16. Porcentagem de provadores para cada gênero

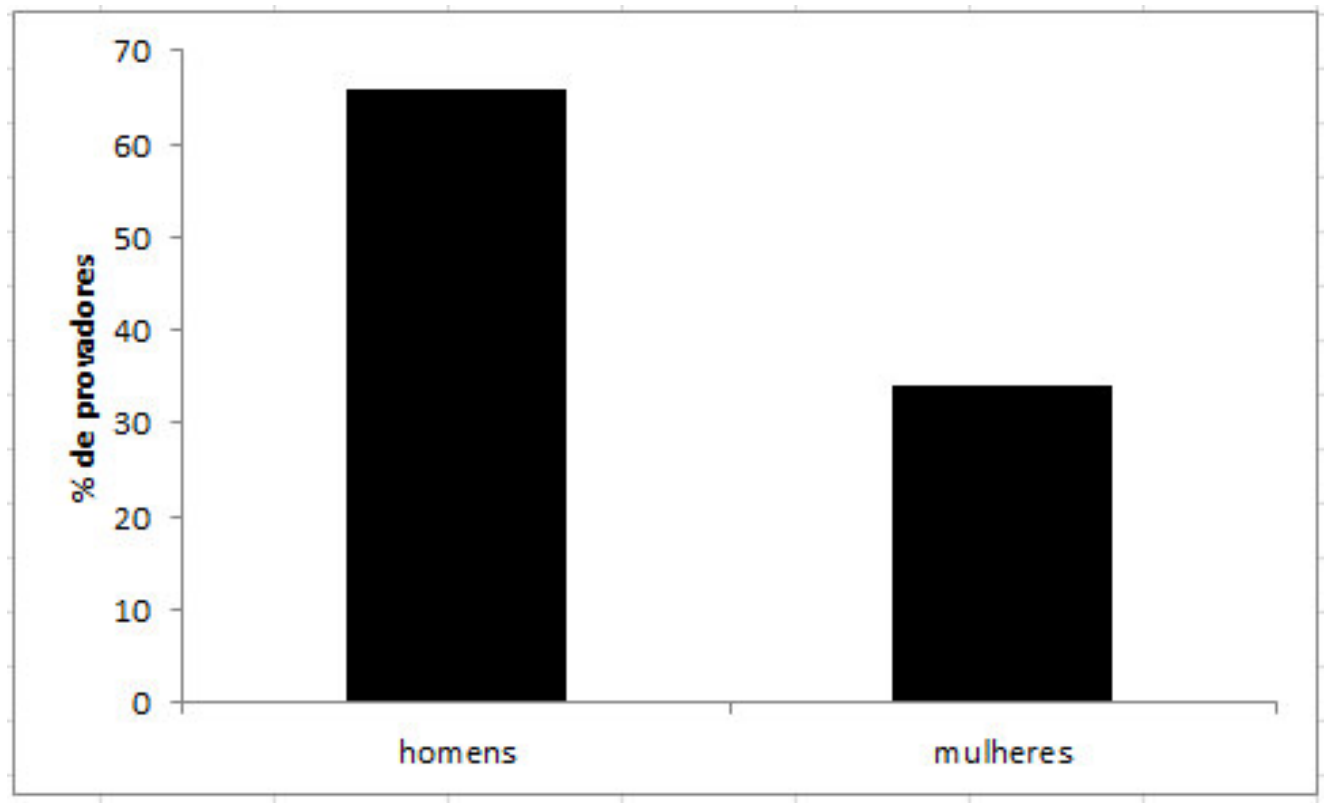

Fonte: Autor

Os avaliadores atribuíram notas de 1 a 9 para os atributos cor, aroma, aparência, sabor e impressão global, cujos resultados foram analisados inicialmente através de ANOVA, para verificar se existia diferença significativa entre as amostras. Comprovada a diferença significativa entre as amostras, foi aplicado o teste de Tukey para comparação das médias, conforme mostra a Tabela 12.

Tabela 12. Médias das notas obtidas para os atributos cor, aroma, aparência, sabor e impressão global na análise sensorial da cerveja aromatizada com café.

\begin{tabular}{cccccc}
\hline Tratamentos & Cor & Aroma & Aparência & Sabor & $\begin{array}{c}\text { Impressão } \\
\text { global }\end{array}$ \\
\hline $\mathbf{1}$ & $5,54 \mathrm{~b}$ & $5,28 \mathrm{~b}$ & $5,66 \mathrm{~b}$ & $4,56 \mathrm{c}$ & $4,98 \mathrm{~b}$ \\
$\mathbf{2}$ & $6,56 \mathrm{a}$ & $5,7 \mathrm{~b}$ & $6,1 \mathrm{ab}$ & $5,0 \mathrm{bc}$ & $5,78 \mathrm{ab}$ \\
$\mathbf{3}$ & $6,20 \mathrm{ab}$ & $6,16 \mathrm{ab}$ & $6,08 \mathrm{ab}$ & $5,78 \mathrm{ab}$ & $5,9 \mathrm{a}$ \\
$\mathbf{4}$ & $6,52 \mathrm{a}$ & $6,74 \mathrm{a}$ & $6,48 \mathrm{ab}$ & $5,96 \mathrm{ab}$ & $6,2 \mathrm{a}$ \\
$\mathbf{5}$ & $6,76 \mathrm{a}$ & $6,84 \mathrm{a}$ & $6,7 \mathrm{a}$ & $6,28 \mathrm{a}$ & $6,6 \mathrm{a}$ \\
\hline
\end{tabular}

Médias seguidas por uma mesma letra na coluna não diferem entre si significativamente ao nível de $5 \%$ de probabilidade.

Quanto a cor, as cervejas identificadas pelos tratamentos 2, 4 e 5 foram mais aceitas pelos julgadores do que a cerveja identificada com o tratamento 1, ou a cerveja sem café, ao nível de 5\% de significância. As cervejas T2, T4 e T5 não diferem com a cerveja T3 em relação a aceitação pelos provadores, o mesmo ocorrendo com relação as cervejas $\mathrm{T} 3$ e $\mathrm{T} 1$. 
Para o atributo aroma, as cervejas identificadas pelos tratamentos 4 e 5 foram mais bem avaliadas pelos consumidores do que as cervejas identificadas pelos tratamentos $1 \mathrm{e}$ 2, cervejas com menos proporções de café. As cervejas T4 e T5 não diferem com a cerveja T3 em relação à aceitação, assim como as cervejas T1 e T2 em relação à cerveja T3.

Com relação à aparência, a cerveja produzida com $45 \%$ de café, identificada como T5, foi mais aceita do que a cerveja sem café, T1. A cerveja T5 não difere com as cervejas T2, T3 e T4 em relação à aceitação pelos degustadores, igualmente ocorrendo com as cervejas T2, T3 e T4 em relação à cerveja T1.

Quanto ao sabor, a cerveja com maior concentração de café, $45 \%$, foi mais bem aceita que a cerveja sem café, identificada como T1. A cerveja T5 não diferiu significativamente das cervejas T3 e T4; da mesma forma que a cerveja T1 em relação à cerveja $\mathrm{T} 2$.

Para o atributo impressão global, as cervejas T3, T4 e T5 foram mais bem avaliadas do que a cerveja T1, que não possui café em sua formulação. As cervejas T3, T4 e T5 não diferiram comparadas com a cerveja T2 em relação à aceitação, de forma similar a cerveja T2 comparada com a cerveja $\mathrm{T} 1$.

Brunelli (2012) produziu cervejas utilizando mel como adjunto em diferentes proporções. Em sua análise sensorial, os provadores preferiram as cervejas produzidas com $40 \%$ de mel, apresentando como nota para o atributo impressão global 6,63; nota essa parecida com a cerveja com $45 \%$ de café deste presente estudo, que apresentou nota de 6,6 para impressão global.

Como pode ser observado, a aceitação das bebidas aromatizadas com café, em diferentes proporções, compreendeu-se entre "gostei ligeiramente" e "gostei moderadamente", sugerindo boa aceitação das bebidas avaliadas.

Os julgadores avaliaram também a intenção de compra das cervejas. Observa-se os resultados apresentados nas Figuras 17 a 21, que a cerveja com maior aceitação foi a do tratamento 5 ( Figura 21, com 45\% de café) com $45 \%$ de aceitação, seguida da cerveja com o tratamento 4 (cerveja aromatizada com 35\% de café) a qual a aceitação foi de $40 \%$ ( Figura 20). Enquanto para o tratamento 2 ( $15 \%$ de café) a aceitação foi de $32 \%$ ( Figura 18). 
Figura 17. Intenção de compra para a cerveja identificada com o tratamento 1 (cerveja aromatizada com $0 \%$ de café).

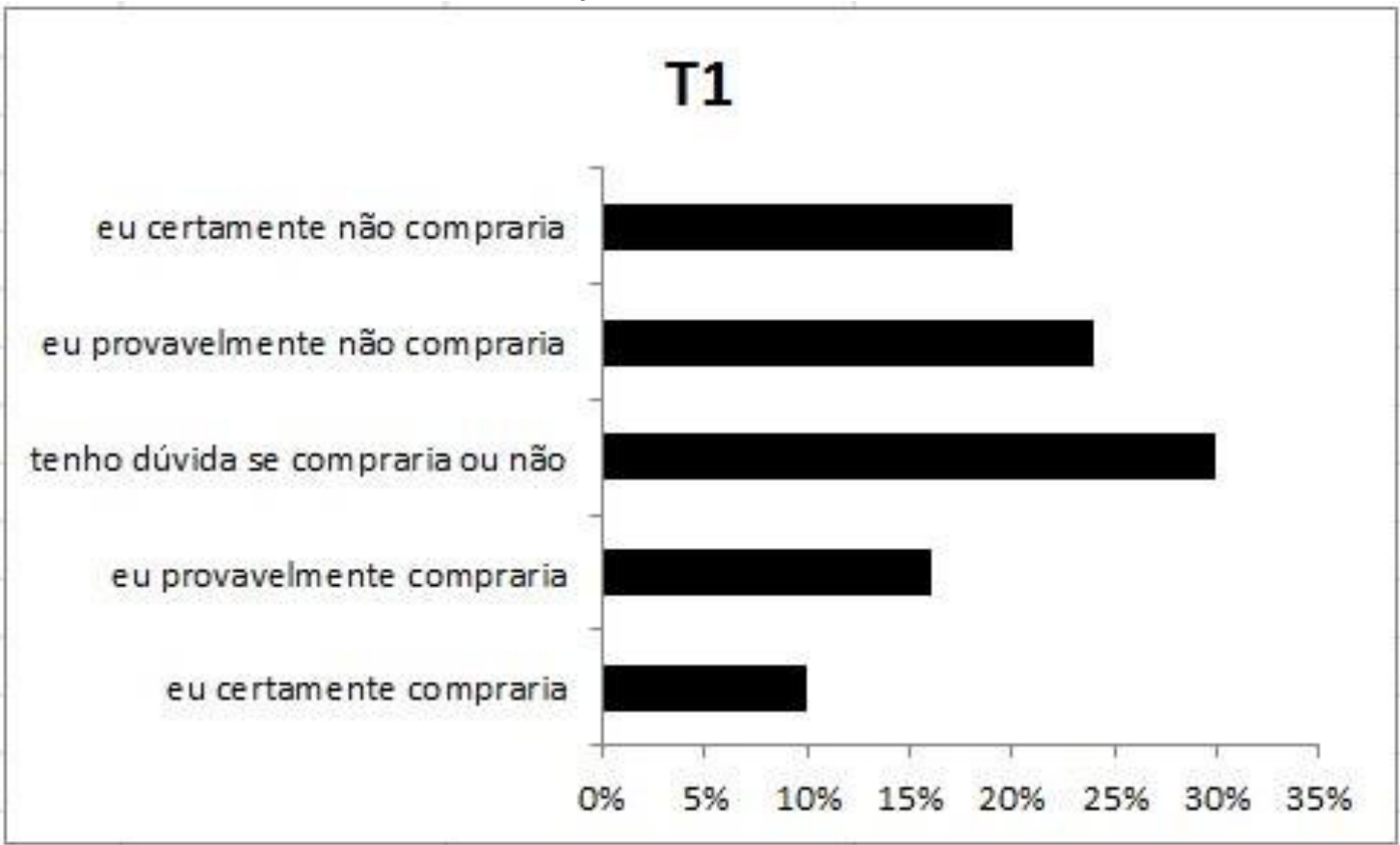

Fonte: Autor

Observa-se na Figura 17, que a cerveja puro malte, apenas $10 \%$ dos julgadores tem certeza que a comprariam e $16 \%$ responderam que provavelmente comprariam. Porém $20 \%$ responderam que certamente não comprariam e $24 \%$ provavelmente não comprariam. Ficaram em dúvida se comprariam ou não, $30 \%$ dos avaliadores.

Figura 18. Intenção de compra para a cerveja identificada com o tratamento 2 (cerveja aromatizada com $15 \%$ de café).

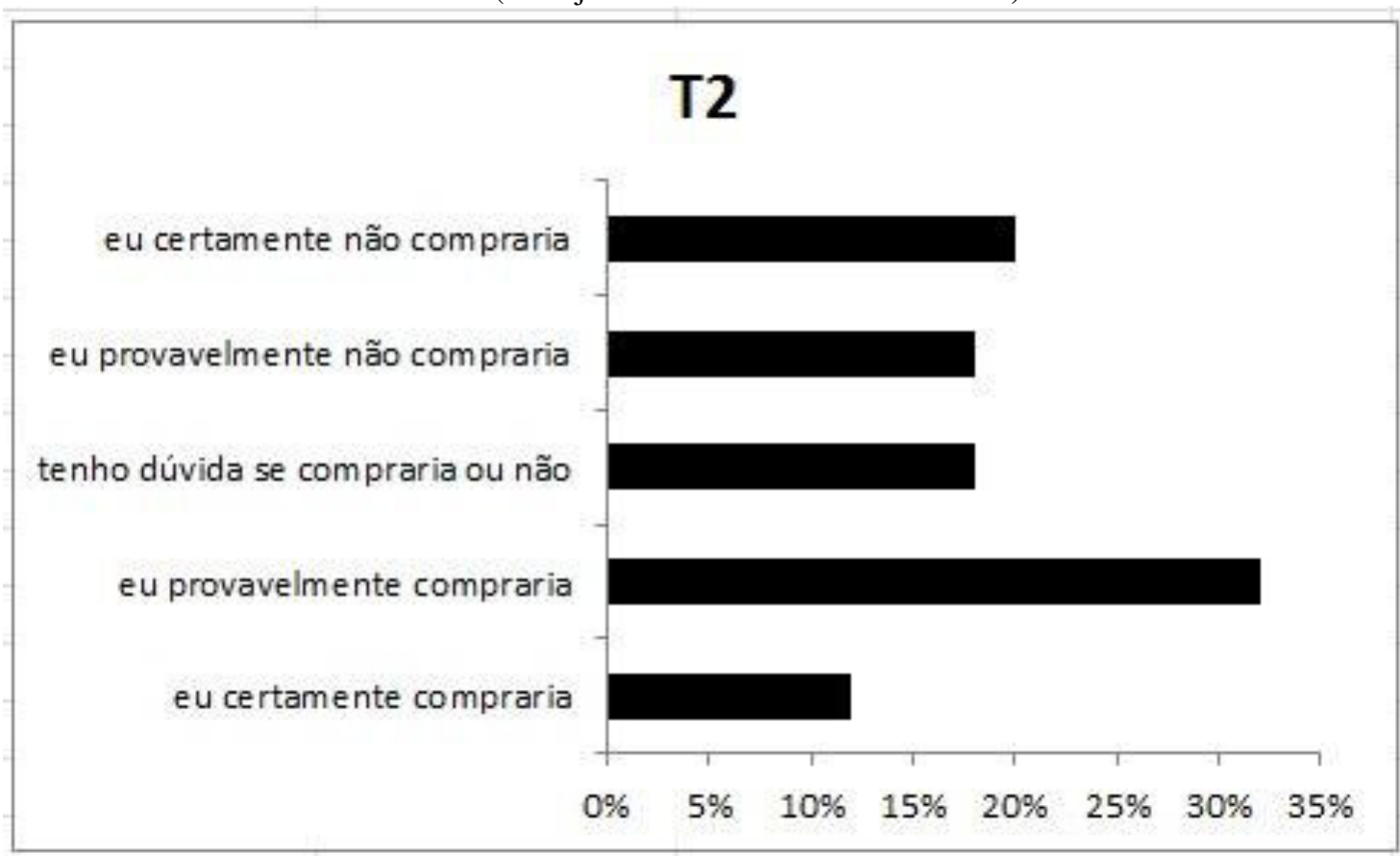

Fonte: Autor 
Na Figura 18, a cerveja com a proporção de 15\% de café, apenas $12 \%$ dos provadores certamente a comprariam e a grande maioria, $32 \%$ responderam que provavelmente comprariam. No entanto $20 \%$ responderam que certamente não comprariam e $18 \%$ provavelmente não comprariam. Ficaram em dúvida se comprariam ou não $18 \%$ dos avaliadores.

Figura 19. Intenção de compra para a cerveja identificada com o tratamento 3 (cerveja aromatizada com $25 \%$ de café).

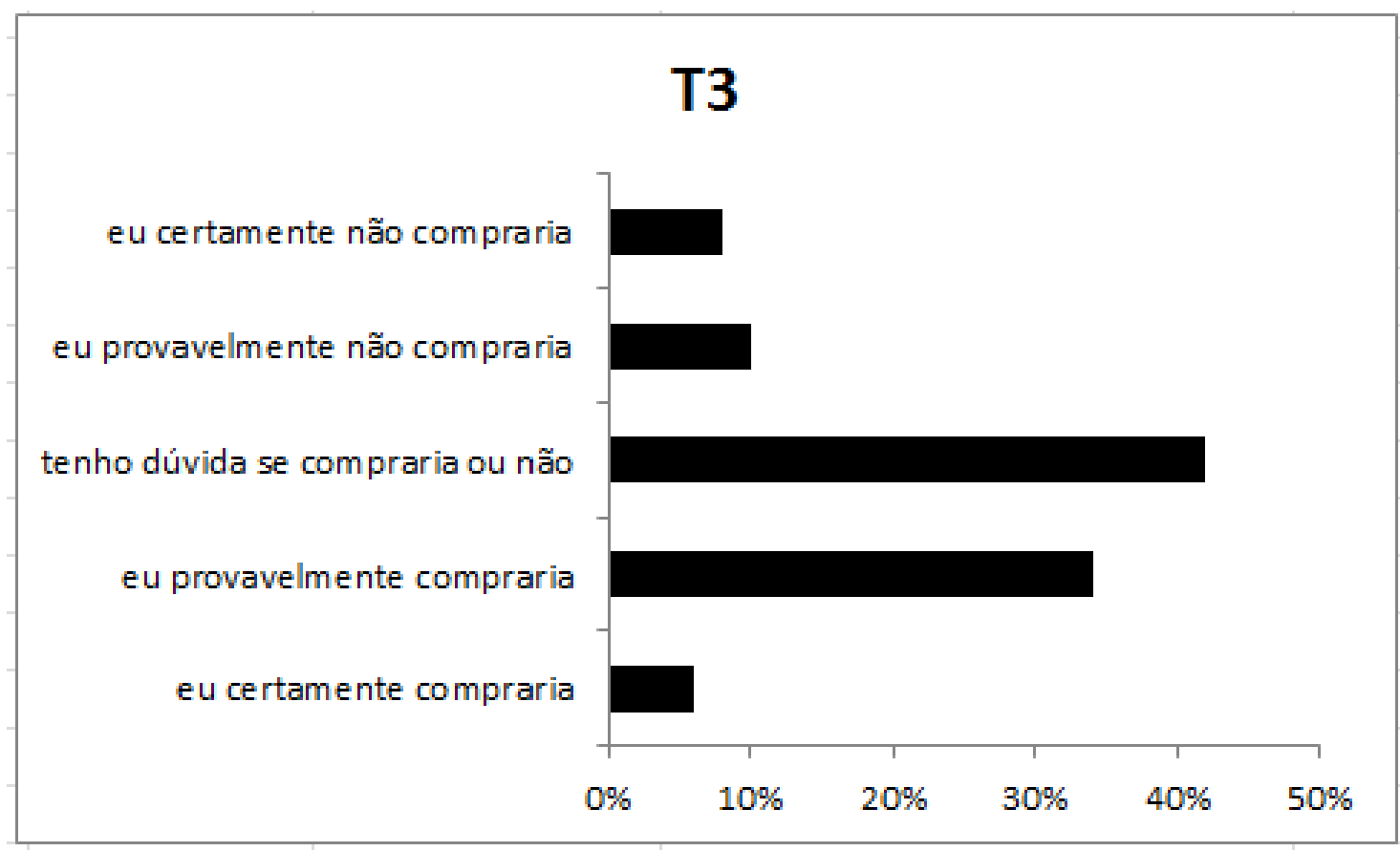

Fonte: Autor

Na Figura 19, a cerveja com a proporção de $25 \%$ de café, apenas $6 \%$ dos julgadores tem certeza que a comprariam e $34 \%$ responderam que provavelmente comprariam. Entretanto, $8 \%$ responderam que certamente não comprariam e 10\% provavelmente não comprariam. Ficaram em dúvida se comprariam ou não, a grande maioria, $42 \%$ dos avaliadores. 
Figura 20. Intenção de compra para a cerveja identificada com o tratamento 4 (cerveja aromatizada com $35 \%$ de café).

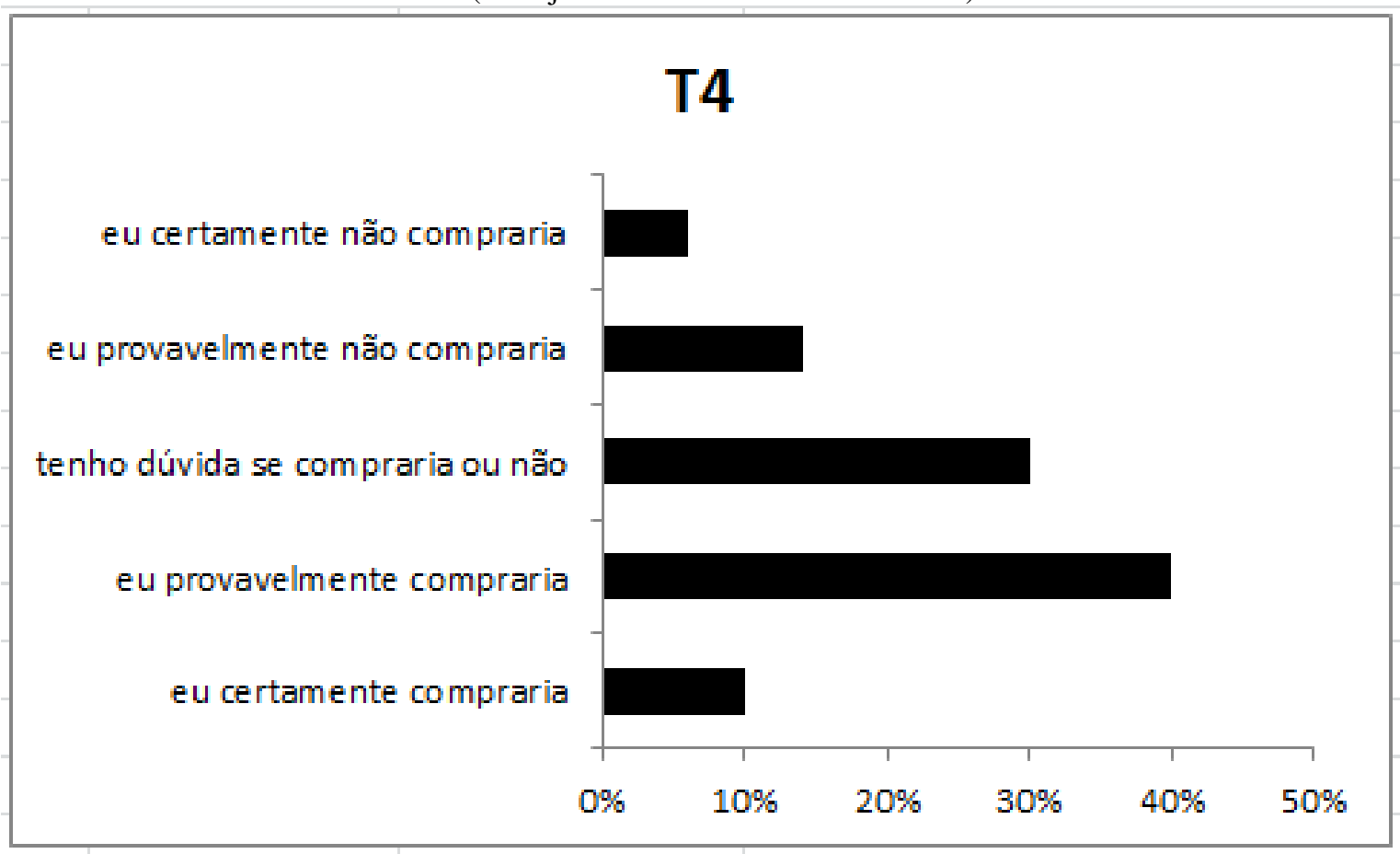

Fonte: Autor

Na Figura 20, a cerveja com a proporção de 35\% de café, apenas $10 \%$ dos provadores possuem absoluta certeza que a comprariam e a grande maioria, $40 \%$, responderam que provavelmente comprariam. Contudo, $6 \%$ responderam que certamente não comprariam e 14\% provavelmente não comprariam. Ficaram em dúvida se comprariam ou não, $30 \%$ dos avaliadores. 
Figura 21. Intenção de compra para a cerveja identificada com o tratamento 5 (cerveja aromatizada com $45 \%$ de café).

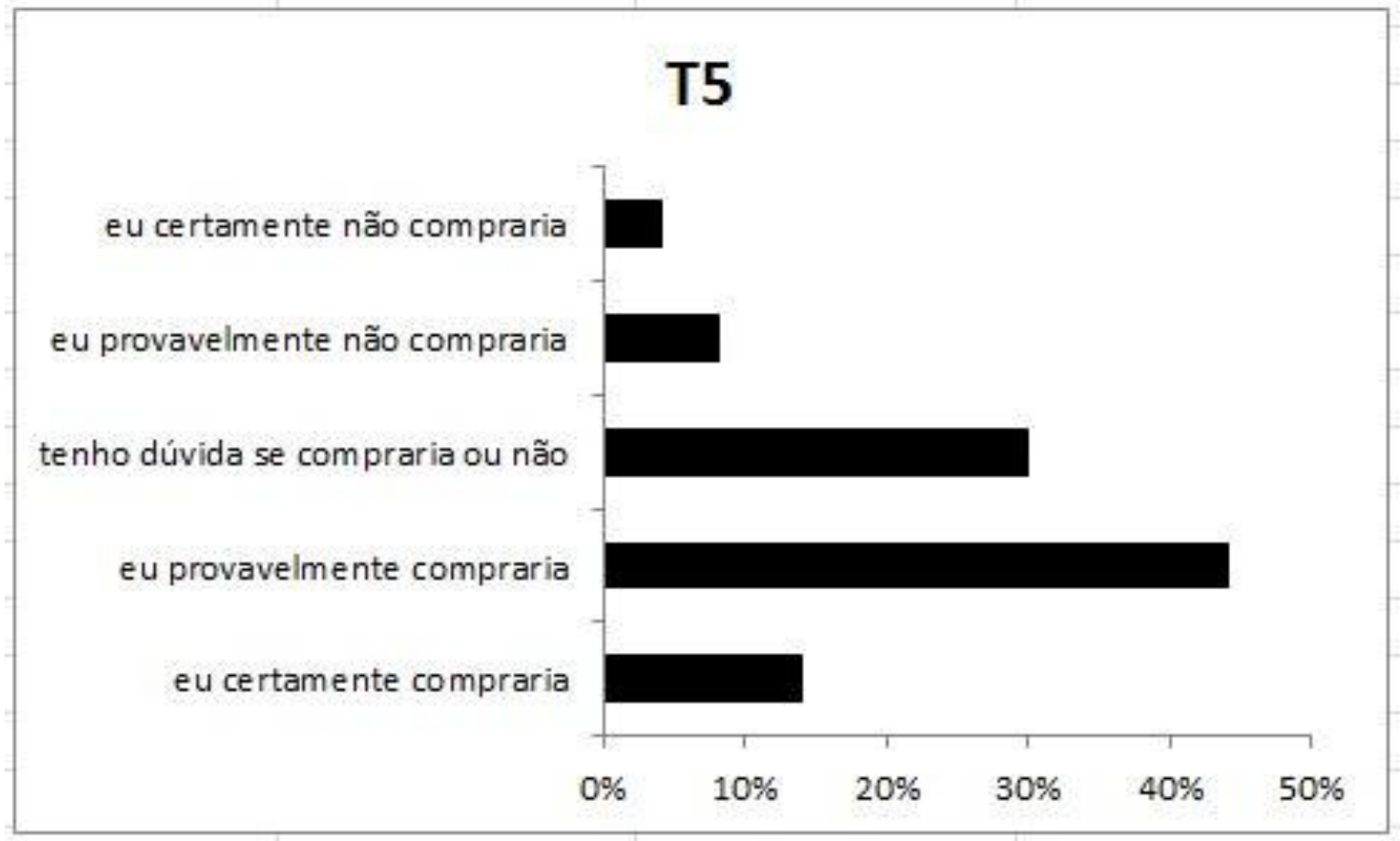

Fonte: Autor

Na Figura 21, a cerveja com a proporção de $45 \%$ de café, apenas $14 \%$ dos julgadores tem certeza que a comprariam e a grande maioria, $44 \%$, responderam que provavelmente comprariam. Apesar disso, 4\% responderam que certamente não comprariam e $8 \%$ provavelmente não comprariam. Ficaram em dúvida se comprariam ou não, $30 \%$ dos avaliadores.

Pelos resultados apresentados nas Figuras 18, 20 e 21 a intençao de compra desses produtos para "eu provavelmente compraria" para as cervejas identificadas com os tratamentos 2, 4 e 5. Esses valores são superiores aos encontrados por Batista (2014), que avaliando a intenção de compra para cervejas usando $10 \%$ e $45 \%$ de pinhão como adjunto obteve escores médios de "talvez comprasse" e "provavelmente não compraria".

$\mathrm{Na}$ Figura 22, pode ser observada a diferença da aparência das bebidas avaliadas sensorialmente, da esquerda para a direita: cerveja aromatizada com $45 \%$ de café, com $35 \%$ de café, com $25 \%$ de café, com $15 \%$ de café e com $0 \%$ de café. 
Figura 22. Amostras de cervejas com suas diferentes proporções de café.

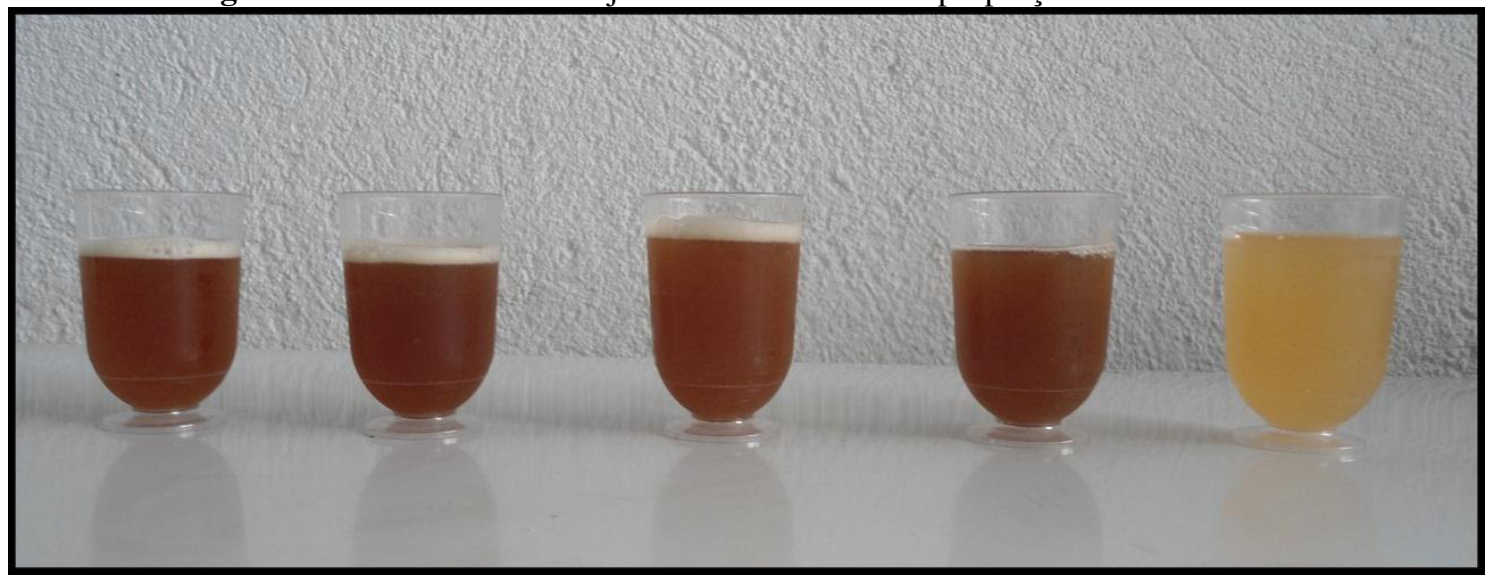

Fonte: Autor

\subsection{ANÁLISES FISICO-QUIMICAS DAS CERVEJAS EM ESCALA PILOTO}

As cervejas foram analisadas no analisador de bebidas Anton Paar, modelo Beer Analyzer 2 e os resultados são apresentados na Tabela 13.

Tabela 13. Comparação das cervejas obtidas com $45 \%$ de café em escala laboratorial e piloto

\begin{tabular}{lcc}
\hline \multicolumn{1}{c}{ Análises } & Escala Laboratorial & Escala Piloto \\
\hline Extrato Real $(\boldsymbol{\%} \mathbf{~ m} / \mathbf{m})$ & 6,02 & 5,6 \\
Extrato Aparente $\left({ }^{\circ} \mathbf{P}\right)$ & 4,09 & 4,17 \\
Extrato Original $\left({ }^{\circ} \mathbf{P}\right)$ & 14,50 & 14,5 \\
Grau Real de Fermentação & 60,34 & 60,64 \\
$(\boldsymbol{\%})$ & 76,29 & 72,4 \\
Grau Aparente de & & \\
Fermentação (\%) & 5,70 & 5,69 \\
Álcool (\% v/v) & 72 & $\mathbf{7 2}$ \\
Tempo de fermentação (h) & & \\
\hline
\end{tabular}

Os valores de Extrato Real e Extrato Aparente estão próximos comparados com os valores das cervejas feitas em escala laboratorial. Os valores obtidos e vistos na Tabela 13 estão similares aos encontrados por Dragone (2007), em seu estudo, um mosto com $15^{\circ} \mathrm{P}$ e fermentando a $15^{\circ} \mathrm{C}$ obteve como valores de extrato real e aparente $6,8{ }^{\circ} \mathrm{P}$ e $4,9{ }^{\circ} \mathrm{P}$ respectivamente. De acordo com Brányik et al. (2004a), o aumento da temperatura de fermentação induz o crescimento celular e aumenta o nível de atividade metabólica do microorganismo, proporcionando dessa forma, maior consumo de açucares do mosto e um aumento na produção de álcool. 
Os graus de fermentabilidade real e aparente apresentaram valores bons e parecidos com as outras cervejas feitas para esse estudo, o que garantiu uma eficiente transformação dos açucares fermentescíveis do mosto em álcool. Esses dados estão dentro da faixa de resultados de composição de mostos apresentados por Meilgaard (2002), para mostos com teores de extrato entre $10,7^{\circ} \mathrm{P}$ e $12,1^{\circ} \mathrm{P}$, este autor relatou os valores de fermentabilidade aparente entre $75 \%$ a $82 \%$.

Os parâmetros fermentativos como rendimento, produtividade em álcool e eficiência da fermentação foram calculados e apresentados na Tabela 14.

Tabela 14. Comparação dos Parâmetros do Processo Fermentativo das cervejas obtidas em escala laboratorial e piloto da cerveja produzida com $45 \%$ de café

\begin{tabular}{|c|c|c|}
\hline Parâmetros Fermentativos & Escala Laboratorial & Escala Piloto \\
\hline Rendimento $\left(Y_{p / s}\right)(g / g)$ & 0,50 & 0,504 \\
\hline $\begin{array}{l}\text { Produtividade em álcool } \\
\left(\text { g. } \mathrm{L}^{-1} \cdot \mathrm{h}^{-1}\right)\end{array}$ & 0,625 & 0,625 \\
\hline $\begin{array}{l}\text { Eficiência da fermentação } \\
(\%)\end{array}$ & 97,8 & 98,6 \\
\hline Tempo de fermentação (h) & 72 & 72 \\
\hline
\end{tabular}

A produtividade em álcool para a cerveja feita em escala piloto apresentou valor semelhante, comparada com as cervejas produzidas em menor escala no mesmo tempo. Mas quando comparado com outros trabalhos como o de Santos (2011), que estudando os parâmetros cinéticos de uma cerveja usando arroz preto como adjunto, obteve valores de 0,29 a $0,33 \mathrm{~g} / \mathrm{L} . \mathrm{h}$ para produtividade em álcool, os resultados obtidos com as cerveja com café apresenta valor maior.

O rendimento da cerveja produzida em maior escala está próximo dos valores das cervejas feitas em menor escala, que apresentaram valores entre 0,48 e $0,50 \mathrm{~g} / \mathrm{g}$ o que pode ser considerado ótimo, já que esses valores estão próximos do $\mathrm{Y}_{\mathrm{p} / \mathrm{s}}$ teórico.

A eficiência da fermentação da cerveja feita em escala piloto de 98,6\% está bem próximo do valor encontrado para a cerveja feita em escala laboratorial 97,8\% e com a mesma concentração de café. Portanto os valores encontrados para os parâmetros fermentativos da cerveja produzida em escala piloto e da cerveja produzida em escala de laboratório estão muito próximos, o que pode inferir que o aumento da escala de fermentação não terá influência no processo fermentativo.

Hendges (2014) comparando os parâmetros cinéticos das fermentações de cervejas utilizando quinoa como adjunto e sendo produzidas em escala piloto e de bancada, 
concluiu que os fatores de rendimento de substrato em etanol foram semelhantes para todas as condições avaliadas.

A Figura 23 mostra o perfil da fermentação para a cerveja obtida em escala piloto com a proporção de café de $45 \%$.

Figura 23. Perfil da fermentação para a cerveja com $45 \%$ de café produzida em escala piloto ( $\triangle$ ) Contagem de células $10^{7} \mathrm{cel} / \mathrm{ml} ;(\bullet)$ Extrato Aparente $\left({ }^{\circ} \mathrm{P}\right) ;(\bullet)$ Teor alcoólico (\% v/v).

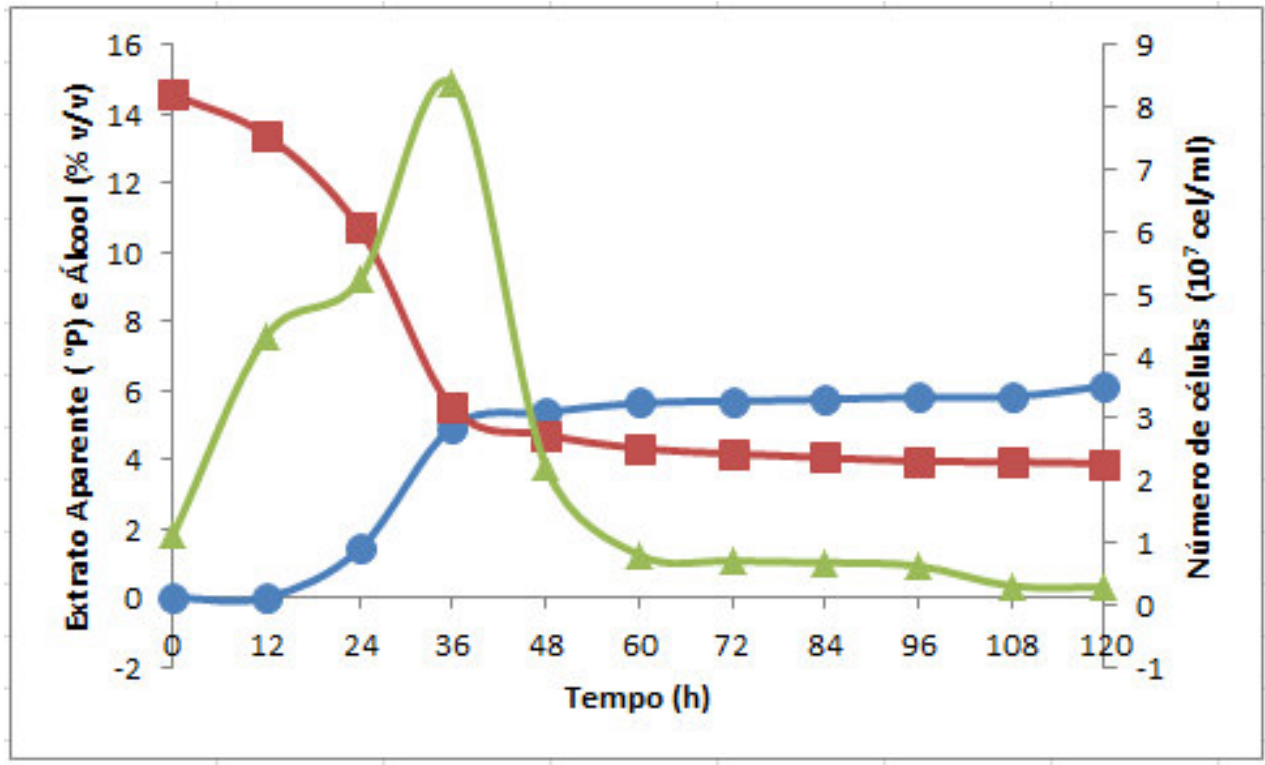

Fonte: Autor

Verifica-se pela Figura 23, que o tempo de análise da fermentação do mosto elaborado em escala piloto, contendo a proporção de $45 \%$ de café, com 72 horas de fermentação foi de 5,69 \%v/v. Porém quando a fermentação continuou até 120 horas, observa-se que o teor de álcool produzido foi maior, chegando a 6,13\% v/v. Mas comparando-se a produtividade, este parâmentro fermentativo com 72 horas foi de 0,625 g/L.h, enquanto a produtividade com 120 horas de fermentação diminui para 0,402 g/L.h. Portanto, industrialmente seria recomendado que a fermentação termine com 72 horas de fermentação, cujo os custos de produção seriam bem menores.

$\mathrm{Na}$ fermentação em escala piloto resolveu-se deixar que a fermentação prosseguisse até que as análises comprovassem estabilidade da concentração de extrato e de álcool, por isso, o tempo de fermentação atingiu 120 horas. Neste tempo a concentração de extrato aparente chegou a $3,88^{\circ} \mathrm{P}$ enquanto a da cerveja feita na mesma concentração de café, mas em escala laboratorial, foi de $4,09{ }^{\circ} \mathrm{P}$. 
Percebe-se que a grande quantidade de extrato, aproximadamente $14,56^{\circ} \mathrm{P}$ foram consumidos rapidamente em 36 horas, e a partir deste momento o consumo continuou, porém, muito mais lentamente.

Observa-se que a formação de álcool iniciou após 12 horas de fermentação, e também, com 36 horas de fermentação a concentração alcoólica no meio fermentado já havia atingido 4,95 \% v/v, aumentando de forma muito lenta também, a partir deste tempo até atingir $6,13 \% \mathrm{v} / \mathrm{v}$.

Quanto ao crescimento celular, inicia-se imediatamente após a inoculação da levedura e atinge o máximo de $8,37 \times 10^{7}$ células $/ \mathrm{mL}$ com 36 horas de fermentação sofrendo progressivo decaimento após este tempo e se mantendo constante após 60 horas de fermentação. Este comportamento indica que as células estão floculando e que já não existe, ou existe muito pouco substrato fermentescíveis no mosto.

\subsection{ANÁLISE DOS HÁBITOS DOS CONSUMIDORES DE CERVEJA}

A fim de analisar os hábitos dos consumidores de cerveja um questionário contendo perguntas referentes à rotina do individuo, foi aplicado para assim identificar as suas preferências em relação ao produto. Em seguida prosseguiu-se com a análise sensorial das cervejas em escala piloto.

Essa análise foi realizada com o objetivo de verificar a percepção do consumidor quanto ao sabor da cerveja e avaliar a aceitação do novo produto no mercado.

\subsubsection{Caracterização dos entrevistados}

O perfil dos entrevistados foi caracterizado por sexo, status de relacionamento e escolaridade, e está representado nas Tabelas 15, 16 e 17.

Tabela 15. Distribuição do sexo dos respondentes

\begin{tabular}{ccc}
\hline Sexo & Fr & \% \\
\hline Masculino & 34 & 67 \\
Feminino & 17 & 33 \\
Total & 51 & 100 \\
\hline
\end{tabular}

Verifica-se pela Tabela 15, um maior porcentual do sexo masculino, 67\%. O maior consumidor de cervejas são os homens, isso se deve ao fato de o principal foco das campanhas publicitárias serem para o público masculino. 
Mas, em um estudo realizado pela LatinPanel, uma das maiores empresas de pesquisa de consumo da América Latina, entre os meses de abril e maio de 2009, indicou que há um crescimento das mulheres como consumidoras de cerveja. Quase metade das entrevistadas; $41,6 \%$ disse preferir a cerveja, valor esse $6 \%$ superior ao encontrado na pesquisa realizada em 2008 (CONFENAR, 2009a).

Tabela 16. Distribuição do status de relacionamento dos respondentes

\begin{tabular}{lcc}
\hline Status de relacionamento & Fr & \% \\
\hline Solteiro & 35 & 69 \\
Namorando & 14 & 4 \\
Casado/União estável & 2 & 27 \\
Divorciado & 0 & 0 \\
Viúvo & 0 & 0 \\
Total & 51 & 100 \\
\hline
\end{tabular}

Observa-se na Tabela 16, que a maior porcentagem, 69\% dos entrevistados eram de solteiros, fato esse que pode ser explicado porque a maioria era composta por universitários. Segundo Kotler \& Keller (2006), as decisões dos compradores são influenciadas por características pessoais como: idade e estágio no ciclo de vida, ocupação, circunstâncias econômicas, personalidade, autoimagem, estilo de vida e valores.

Tabela 17. Distribuição da escolaridade dos respondentes

\begin{tabular}{lcc}
\hline \multicolumn{1}{c}{ Escolaridade } & Fr & \% \\
\hline $\mathbf{1}^{\mathbf{0}}$ Grau & 1 & 2 \\
$\mathbf{2}^{\mathbf{o}}$ Grau & 18 & 35 \\
Superior & 26 & 51 \\
Pós-Graduação & 6 & 12 \\
Total & 51 & 100 \\
\hline
\end{tabular}

Como os questionados eram estudantes e funcionários da EEL/USP percebe-se pelos resultados apresentados na Tabela 17, que a grande maioria era composta por estudantes do ensino superior e da pós-graduação (mestrado ou doutorado), e encontravam-se na faixa de 18 a 27 anos. O mercado brasileiro de cerveja é composto em sua maioria pela população jovem (ROSA, COSENZA E LEÃO, 2006).

As mudanças nos hábitos de consumo dos alimentos e das bebidas são consequência do crescimento da mão de obra feminina no mercado de trabalho, da redução do tamanho da família e da evolução no número de pessoas que estudam e, 
muitas vezes, moram fora (SOUZA, 2005). Soma-se a isso consumidores cada vez mais conscientes e ávidos por informações antes de tomarem a decisão de compra.

\subsubsection{Análise dos hábitos}

A fim de conhecer o hábito de preferência dos consumidores em relação ao tipo de bebida consumida, a frequência de consumo e o local onde preferem consumir as bebidas, um questionário foi apresentado e os resultados estão mostrados nas Tabelas 18, 19 e 20.

A Tabela 18, mostra os resultados sobre a preferência dos entrevistados quanto ao tipo de bebida.

Tabela 18. Bebida alcoólica preferida pelos respondentes

\begin{tabular}{lcc}
\hline \multicolumn{1}{c}{ Bebida alcoólica } & Fr & $\%$ \\
\hline Vinho & 8 & 15 \\
Vodka & 7 & 14 \\
Whisky & 3 & 6 \\
Cerveja & 32 & 63 \\
Outra & 1 & 2 \\
Total & 51 & 100 \\
\hline
\end{tabular}

Os resultados mostram claramente que a grande maioria, $63 \%$ dos entrevistados preferem a cerveja em relação às outras bebidas alcoólicas, como o vinho, outra bebida fermentada que tem a preferência de $15 \%$ e vodka, bebida destilada que teve a preferência de $14 \%$ dos perguntados.

A cerveja possui um mercado consumidor fiel e crescente, constituindo-se um dos principais produtos que compõem o setor de bebidas (ROSA, CONSENZA E LEÃO, 2006).

Para a análise dos hábitos de consumo, os universitários declararam a frequência de consumo de cerveja, cujas respostas encontram-se apresentadas na Tabela 19.

Tabela 19. Frequência de consumo de cerveja

\begin{tabular}{lcc}
\hline Frequência de consumo & Fr & $\%$ \\
\hline Diariamente & 1 & 2 \\
2 a 3 vezes por semana & 18 & 35 \\
1 vez por semana & 14 & 27 \\
a cada 15 dias & 8 & 16 \\
uma vez por mês & 10 & 20 \\
Total & 51 & 100 \\
\hline
\end{tabular}


A grande maioria, $35 \%$ consome cerveja de duas a três vezes por semana, seguido de $27 \%$ que consome uma vez por semana, de $20 \%$ que consomem uma vez por mês e de apenas $2 \%$ que consomem diariamente.

A fim de conhecer a preferência dos entrevistados quanto ao local de consumo, foi perguntado qual o local que eles preferem consumir cervejas. Os resultados estão apresentados na Tabela 20.

Tabela 20. Local onde prefere consumir cervejas

\begin{tabular}{lcc}
\hline \multicolumn{1}{c}{ Local } & Fr & $\%$ \\
\hline Bares & 10 & 19 \\
Festas/baladas/churrascos & 21 & 42 \\
Na casa de amigos & 8 & 16 \\
Restaurantes & 2 & 4 \\
Em sua própria casa & 10 & 19 \\
Total & 51 & 100 \\
\hline
\end{tabular}

De acordo com os resultados obtidos a cerveja é mais consumida por $42 \%$ dos entrevistados, em ambientes sociais como festas, baladas e churrascos, seguido de $19 \%$ que preferem consumir em bares ou na própria casa e de $16 \%$ que preferem consumir a bebida na casa de amigos.

Kayo (2006) apontou que beber na companhia dos amigos é a escolha de mais da metade dos consumidores. Outros preferem a companhia do namorado(a) ou da família. Em seu estudo, os lugares preferidos para consumo de cerveja foram nessa ordem: festas, baladas, bares, praia e na casa de amigos, o que corroboram com os resultados obtidos no presente trabalho.

A fim de compreender a preferência do consumidor quanto, aos aspectos que mais influenciam na sua tomada de decisão para o consumo, foi formulada uma questão onde foi proposto para os entrevistados que escolhessem três itens preferidos por eles entre: sabor, preço, marca, efeito do álcool e a cerveja que meus amigos e familiares consomem. Foram escolhidos os itens sabor, preço e marca. Os resultados obtidos estão mostrados na Tabela 21.

Tabela 21. Três itens considerados como mais importantes para o consumo da cerveja

\begin{tabular}{ccc}
\hline Itens importantes & Fr & $\%$ \\
\hline Sabor & 42 & 82 \\
Preço & 22 & 43 \\
Marca & 16 & 31 \\
\hline
\end{tabular}


Observa-se que $82 \%$ preferem o item sabor da cerveja, seguido de $43 \%$ que escolhem a bebida pelo preço e de $31 \%$ que são fiéis a marca.

O principal fator que leva os consumidores a escolherem determinadas marcas de cerveja é o sabor, seguido do "costume" ou "tradição", revelando assim a importância dos fatores culturais como razão de escolha da marca de cerveja (CARVALHO et al, 2008).

Preços e marcas ainda são elementos extrínsecos ao produto e são os mais importantes, quando se trata de decidir quais produtos alimentares comprar (AMPUERO; VILA, 2006).

A marca influencia a percepção, a atitude e no comportamento do consumidor, pela confiança conquistada em relação aos demais produtos ( JAEGER, 2006).

Em um estudo realizado por Carvalho et al. (2008) verificaram que a marca pode ser utilizada como um instrumento de diferenciação de um produto no mercado frente aos concorrentes, e principalmente na mente do consumidor, pois se torna a forma mais clara de identificação daquele dentre uma grande variedade disponível, proporcionando ao comprador a identidade necessária para a tomada de decisão de compra.

Apesar da marca ser muito procurada na hora das compras, há pessoas que gostam de experimentar cervejas de marcas pouco conhecidas, como algumas cervejas artesanais ou especiais. E há pessoas que nem conhecem esse tipo de cerveja, por isso foi perguntado se os questionados conheciam essas bebidas e se já tomaram alguma vez. As respostas estão apresentadas na Tabela 22.

Tabela 22. Levantamento feito entre os entrevistados sobre o consumo de cerveja artesanal

\begin{tabular}{lcc}
\hline \multicolumn{1}{c}{ Consumo } & Fr & $\%$ \\
\hline Já consumiu e gostou & 38 & 74 \\
Já consumiu e não gostou & 3 & 6 \\
$\begin{array}{l}\text { Não consumiu e gostaria } \\
\text { de experimentar }\end{array}$ & 9 & 18 \\
$\begin{array}{l}\text { Não consumiu e não } \\
\text { gostaria de experimentar }\end{array}$ & 0 & 0 \\
$\begin{array}{l}\text { Não sabe o que é cerveja } \\
\text { artesanal }\end{array}$ & 1 & 2 \\
Total & 51 & 100 \\
\hline
\end{tabular}

Pelas respostas obtidas, $74 \%$ dos entrevistados já experimentaram esse tipo de bebida e gostaram contra apenas $6 \%$ que experimentaram e não gostaram. 
As cervejas artesanais ou especiais são aquelas produzidas geralmente em pequena escala, em microcervejarias. Essas cervejas caracterizam-se por serem um produto mais encorpado e de aroma e sabor mais pronunciados, sendo consumidas principalmente por pessoas mais exigentes em termos de qualidade sensorial, que buscam um produto diferenciado, independente do preço (ARAÚJO; SILVA; MINIM, 2003).

Os dados indicam que a participação das cervejas especiais no mercado cervejeiro brasileiro atingiu aproximadamente 5,5\%, em 2008, o que representou um montante de 2 bilhões de reais. Mas esse resultado, é ainda bastante inferior ao de outros países. Na Europa Ocidental, as cervejas "Gourmet" chegam a ocupar 50\% do mercado total (GONÇALVES, 2009b).

$\mathrm{Na}$ tabela 23, os provadores declararam qual a sua preferência quanto ao tipo de cerveja.

Tabela 23. Preferência quanto ao tipo de cerveja

\begin{tabular}{lcc}
\hline \multicolumn{1}{c}{ Tipo de cerveja } & Fr & \% \\
\hline Pilsen & 27 & 53 \\
IPA & 6 & 12 \\
Weissbier & 13 & 25 \\
Porter & 4 & 8 \\
Outra & 1 & 2 \\
Total & 51 & 100 \\
\hline
\end{tabular}

Conforme era de se esperar a maioria, 53\% dos perguntados preferem a cerveja tipo Pilsen, cerveja Lager ou de baixa fermentação, cerveja mais produzida e mais consumida no mundo. Mas há um crescimento pelo interesse nas cervejas de outros estilos, como a cerveja de trigo (Weissbier) que teve $25 \%$ da preferência seguida do estilo IPA, cerveja que apresenta elevado teor de IBU, portanto muito amarga, com 12\%; e do tipo Porter, cerveja de coloração preta, por ser produzida com malte tostado, que teve $8 \%$ de preferência.

No Brasil, o consumo da cerveja tipo Pilsen chega a $98 \%$ do total, ficando o restante para as cervejas do tipo Bock, Light, Malzibier, Stout e outras (SINDICERV,2010).

A Tabela 24 mostra a percepção do consumidor quanto a percepção de diferença entre as marcas. 
Tabela 24. Percepção do sabor entre as marcas de um mesmo tipo de cerveja

\begin{tabular}{ccc}
\hline $\begin{array}{c}\text { Percepção da diferença } \\
\text { de sabor entre as marcas }\end{array}$ & Fr & $\%$ \\
\hline Sim & 49 & 96 \\
Não & 2 & 4 \\
Total & 51 & 100 \\
\hline
\end{tabular}

A grande maioria dos entrevistados, $96 \%$ percebem a diferença de sabor entre as distintas marcas de um mesmo tipo de cerveja, por isso a demanda agora é que o consumidor se torne cada vez mais exigente, quanto ao sabor da cerveja.

Entre cinco atributos: sabor, aroma, teor alcoólico, amargor e doçura; foi perguntado aos entrevistados quais, na opinião deles, eram os três mais determinantes para a qualidade da cerveja. Os mais escolhidos foram sabor, aroma e doçura cujos resultados estão apresentados na Tabela 25.

Tabela 25. Atributos considerados mais importantes para uma cerveja de acordo com os entrevistados.

\begin{tabular}{ccc}
\hline Atributos importantes & Fr & $\%$ \\
\hline Sabor & 45 & 88 \\
Aroma & 21 & 41 \\
Doçura & 18 & 35 \\
\hline
\end{tabular}

Nota-se que o aroma é uma característica muito apreciada nas cervejas, portanto esse é um atributo que deve ser mais explorado na formulação de novos produtos, escolhido por $88 \%$ dos entrevistados. A intensidade da doçura também serve como parâmetro para a inovação em produtos, e teve a preferência por $35 \%$ das pessoas. O aroma teve a preferência por $41 \%$ dos perguntados.

Portanto, a cerveja considerada ideal pelos consumidores seria uma com sabor acentuado, aroma marcante e com uma doçura equilibrada.

Como cerveja de café não é uma bebida muito conhecida, foi perguntado aos entrevistados se eles já haviam provado alguma cerveja deste tipo. As respostas estão apresentadas na Tabela 26.

Tabela 26. Questionamento feito aos respondentes sobre o consumo ou não de cerveja de café.

\begin{tabular}{ccc}
\hline $\begin{array}{c}\text { Pessoas que já tomaram } \\
\text { cerveja com café }\end{array}$ & Fr & $\%$ \\
\hline Sim & 17 & 33 \\
Não & 34 & 67 \\
Total & 51 & 100 \\
\hline
\end{tabular}


Observa-se que $33 \%$ responderam que já haviam tomado alguma cerveja que continha café em sua formulação, e $67 \%$ ainda não haviam provado. Há poucas cervejas com café no mercado e muitas pessoas, como mostrou o levantamento, ainda não conhecem essas cervejas por não serem muito difundidas.

Das pessoas que responderam que já tomaram alguma cerveja com café, foi perguntado se elas gostaram da bebida. Os resultados estão apresentados na Tabela 27.

Tabela 27. Questionamento feito aos respondentes que tomaram cerveja com café.

\begin{tabular}{ccc}
\hline $\begin{array}{c}\text { Gostaram da cerveja com } \\
\text { café }\end{array}$ & Fr & $\%$ \\
\hline Sim & 12 & 71 \\
Não & 5 & 29 \\
Total & 17 & 100 \\
\hline
\end{tabular}

Observa-se que dos respondentes que já tomaram cerveja com café, $71 \%$ responderam que gostaram da cerveja, apenas $29 \%$ responderam que não gostaram. Por isso, podemos inferir que uma cerveja com café seria muito bem aceita pelos consumidores.

\subsection{ANÁliSE SENSORIAL DAS CERVEJAS PRODUZIDAS EM ESCALA PILOTO}

As bebidas produzidas em escala piloto foram avaliadas sensorialmente por 59 provadores não treinados, com a faixa etária entre 18 a 49 anos, sendo $32 \%$ mulheres e $83 \%$ homens. A Figura 24 mostra a porcentagem de provadores para cada gênero. 
Figura 24. Porcentagem de provadores para cada gênero

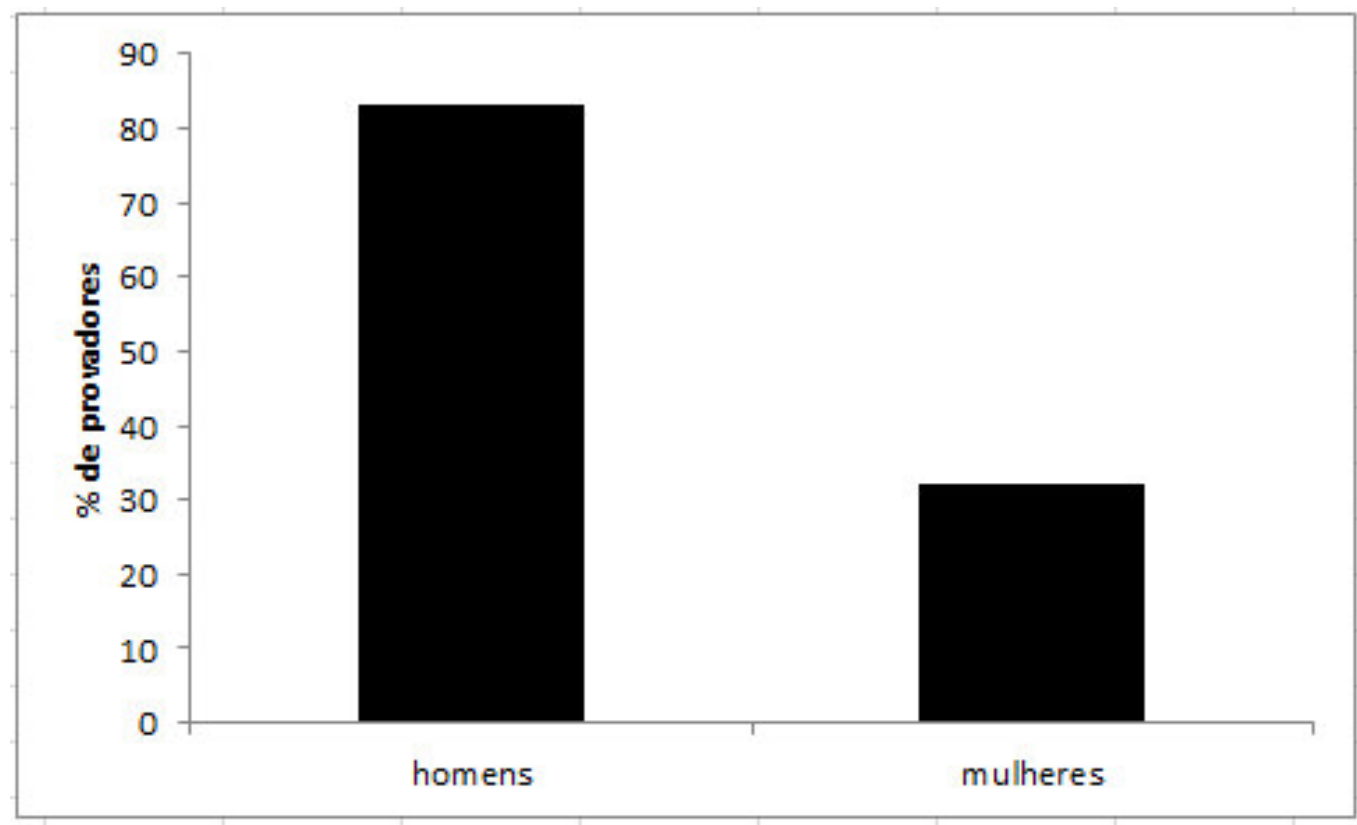

Fonte: Autor

Como na análise sensorial, com as cervejas feitas em escala laboratorial, a mais bem avaliada foi a cerveja que recebeu o tratamento T5, cerveja produzida com $45 \%$ de café, com esta concentração de café foi produzida uma cerveja escala piloto e esta bebida foi comparada com uma cerveja líder de mercado, também feita com café.

Os avaliadores atribuíram notas de 1 a 9 para os atributos doçura, aroma, sabor, amargor e impressão global, cujos resultados foram analisados inicialmente através de ANOVA, para verificar se existia diferença significativa entre as amostras. Comprovada a diferença significativa entre as amostras, foi aplicado o teste de Tukey para comparação das médias, conforme mostra a Tabela 28.

Tabela 28. Médias das notas obtidas para os atributos doçura, aroma, sabor, amargor e impressão global na análise sensorial da cerveja aromatizada com café.

\begin{tabular}{cccccc}
\hline Amostras & Doçura & Aroma & Sabor & Amargor & $\begin{array}{c}\text { Impressão } \\
\text { Global }\end{array}$ \\
\hline Comercial & $6,10 \mathrm{a}$ & $6,81 \mathrm{a}$ & $6,35 \mathrm{a}$ & $6,25 \mathrm{a}$ & $6,74 \mathrm{a}$ \\
Cerveja T5 & $5,47 \mathrm{a}$ & $6,95 \mathrm{a}$ & $5,70 \mathrm{a}$ & $5,61 \mathrm{~b}$ & $6,28 \mathrm{a}$ \\
\hline
\end{tabular}

Médias seguidas por uma mesma letra na coluna não diferem entre si significativamente ao nível de 5\% de probabilidade, pelo teste de Tukey.

Observa-se que não houve diferença significativa para os atributos doçura, aroma, sabor e impressão global entre a cerveja produzida na Planta Piloto e a cerveja comercial considerada líder de mercado. Nos comentários sobre as cervejas, os provadores 
apontaram como mais aromática a cerveja produzida com $45 \%$ de café comparada com a amostra comercial.

Quanto ao amargor, a cerveja comercial foi considerada a mais amarga pelos provadores do que a cerveja produzida em escala piloto, ao nível de 5\% de significância. Comparando o teor de IBU de ambas as cervejas, a comercial possui 40 IBU, enquanto a cerveja com $45 \%$ de café tem 36,8 IBU, e isto foi detectado pelos avaliadores.

Ambas as cervejas apresentaram notas entre 6 e 7, compreendendo entre " gostei ligeiramente" e "gostei moderadamente" sugerindo boa aceitação das bebidas, não havendo diferença significativa $(\mathrm{p}<0,05)$ entre as amostras, com relação a impressão global.

Carvalho (2009) produziu cerveja com banana com o objetivo de aromatizar e dar um sabor diferente às cervejas. Avaliando através da Análise Sensorial concluiu que não houve diferença significativa quanto ao grau de aceitação entre os produtos correspondentes às amostras experimentais otimizadas e as amostras do mercado, ou seja, as amostras de cerveja com banana foram tão bem aceitas pelo consumidor quanto às amostras de cerveja do mercado; resultado este semelhante encontrado no presente estudo.

Os julgadores avaliaram também a intenção de compra das cervejas cujos resultados estão mostrados nas Figuras 25 e 26.

Figura 25. Intenção de compra para a cerveja líder de mercado.

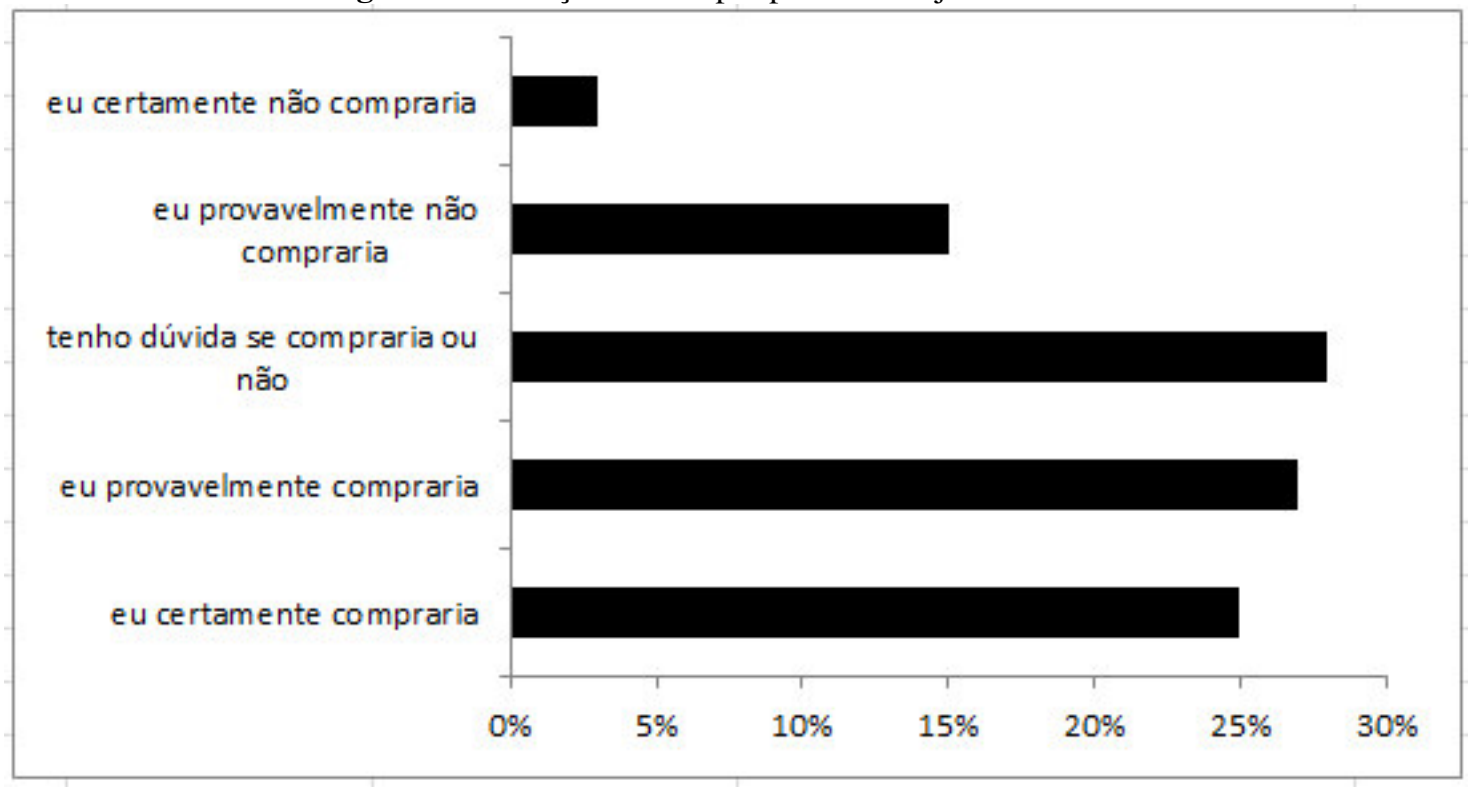

Fonte: Autor 
Observa-se na Figura 25, que na intenção de compra da cerveja comercial, apenas $25 \%$ dos julgadores tem certeza que a comprariam e $27 \%$ responderam que provavelmente comprariam. Todavia, $3 \%$ responderam que certamente não comprariam e $15 \%$ provavelmente não comprariam. Ficaram em dúvida se comprariam ou não, a grande maioria, $28 \%$ dos avaliadores.

Figura 26. Intenção de compra para a cerveja que recebeu o tratamento 5 (cerveja aromatizada com $45 \%$ de café) e foi produzida em escala piloto.

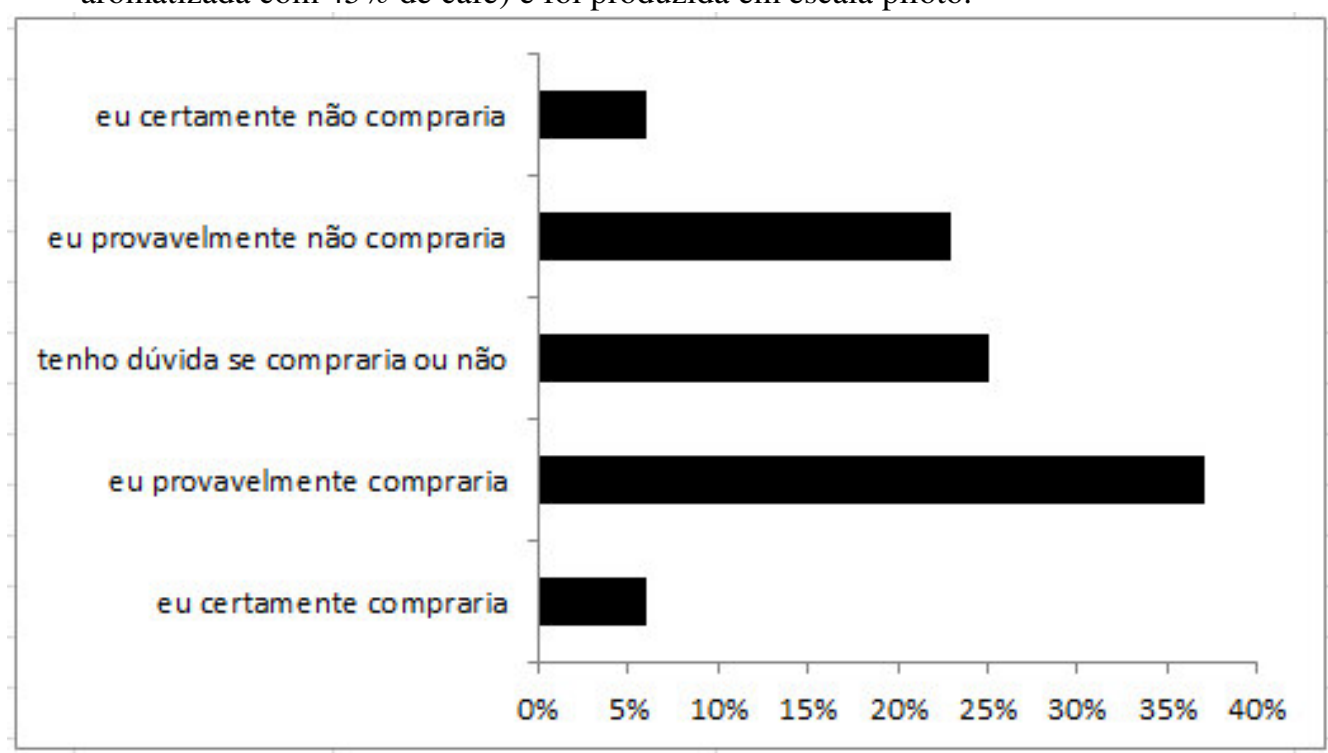

Fonte: Autor

Na Figura 26, a cerveja com a proporção de $45 \%$ de café e produzida em escala piloto, apenas 6\% dos provadores certemente a comprariam e a grande maioria, $37 \%$ responderam que provavelmente comprariam. Não obstante, $6 \%$ responderam que certamente não comprariam e $23 \%$ provavelmente não comprariam. Ficaram em dúvida se comprariam ou não, $25 \%$ dos avaliadores.

Na Figura 27 pode ser observada a diferença da cor das bebidas avaliadas sensorialmente, da esquerda para a direita: cerveja aromatizada com $45 \%$ de café e a cerveja líder de mercado. 
Figura 27. Amostras de cervejas utilizadas na análise sensorial

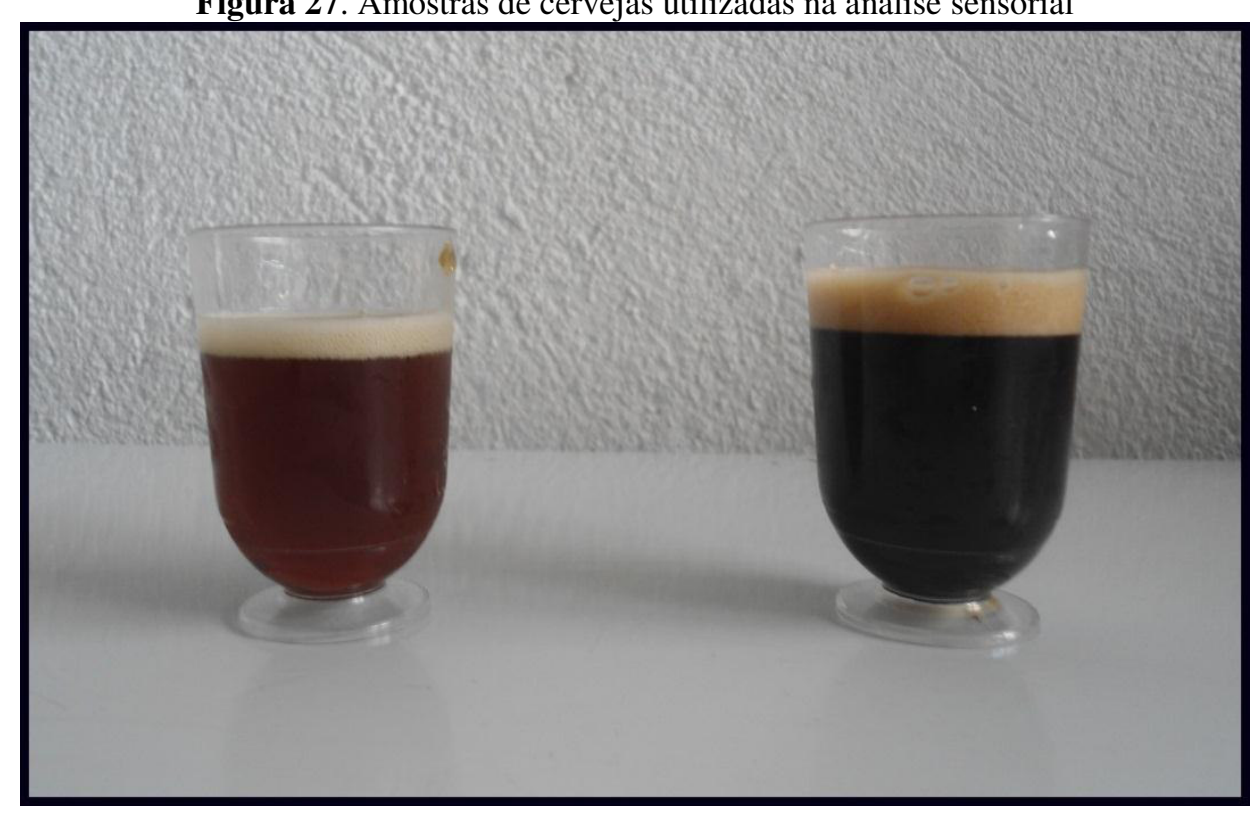

Fonte: Autor 


\section{CONCLUSÕES}

- O café poderá ser utilizado como aromatizante na preparação de cerveja, sem influenciar no processo fermentativo e auxiliar no poder antioxidante da bebida.

- O teor alcóolico das cervejas ficaram entre 5,17 e $5,78 \%$ v/v. O grau de fermentabilidade Real ficou entre 60,34 a $66,67 \%$, o fator de rendimento em álcool, variou entre 93,9 e 97,8g/g, a produtividade entre 0,57 e $0,63 \mathrm{~g} / \mathrm{L} . \mathrm{h}$ e eficiência do processo fermentativo ficou entre $93,8 \%$ e $97,8 \%$. Os resultados demonstraram que as diferentes concentrações de café não interferiram no processo fermentativo.

- Nas análises físico-químicas da cerveja produzida em escala piloto notaram-se valores próximos dos valores das cervejas obtidas em escala laboratorial, sugerindo que a ampliação de escala não interfere no processo.

- Na análise sensorial utilizando a escala do ideal, a grande maioria (57\%) dos julgadores consideraram a bebida usando $45 \%$ de café, como uma bebida com sabor de café muito mais intenso que o ideal.

- A análise sensorial comparando a cerveja produzida em escala piloto aromatizada com $45 \%$ de café e uma cerveja comercial apresentou notas ótimas para todos os atributos e para a intenção de compra.

- Conclui-se portanto que o café poderá ser empregado como aromatizante no processo de produção de cerveja com até $45 \%$ de café. 


\section{REFERÊNCIAS}

ABIC - Associação Brasileira Da Indústria de Café. História do Café. Disponível em: < http://www.abic.com.br/publique/cgi/cgilua.exe/sys/start.htm?sid=38> Acesso em: 26 mar. 2014.

ABRAhÃO, S. A.; PEREIRA, R. G. F. A.; DUARTE, S. M. S.; LIMA, A. R.; ALVARENGA, D. J.; FERREIRA, E. B.; Compostos bioativos e atividade antioxidante do café. Ciência e Agrotecnologia (UFLA), v. 34, p. 414-420, 2010.

AIZEMBERG, R. ; ALMEIDA E SILVA, J. B. Preliminary assessment of water quality to be used in the brewing process. In: BRAZILIAN MEETING ON CHEMISTRY OF FOOD AND BEVERAGES, 2012. Araraquara - SP. Anais. UNESP, 2012. p. 70.

ALMEIDA , N. E. C. Reatividade de iso- $\alpha$-ácidos e seus derivados hidrogenados frente ao radical 1-hidroxietila: implicações na perda de qualidade sensorial da cerveja.2011.115 f.Dissertação (Mestrado em Ciências) - Universidade de São Paulo, São Carlos - SP.

ALMEIDA, R. B. ; SILVA, J. B. A. E. ; LIMA, U. A. ; ASSIS, A. N. . Evaluation of fermentation parameters during high-gravity beer production. Brazilian Journal of Chemical Engineering, v. 18, n.4, p. 459-465, 2001.

AMPUERO, O. ; VILA, N. Consumer perceptions of product packaging. Journal of Consumer Marketing, Bingley, UK, V. 23, n. 2 p. 100-112, 2006.Disponível em:<http://www.emeraldinsight.com/Insight/viewContentItem.do;jsessionid=7226A5 5FD741D96AC64D667A735061C2? contentType=Article\&hdAction=Inkpdf\&conte $\mathrm{ntId}=1549947 \& \mathrm{dType}=\mathrm{SUB} \&$ history=false $>$.Acesso em: 18 jun 2015.

ANDRADE, C. M. Obtenção de chope utilizando arroz preto (Oryza Sativa) como adjunto de malte.2007.f. 78. Dissertação (Mestrado em Biotecnologia Industrial) Escola de Engenharia de Lorena, Universidade de São Paulo, Lorena, 2007.

AQUARONE, E.,BORZANI, W.,SCHMIDELL, W., LIMA, U. A. Biotecnologia Industrial. São Paulo: Edgard Blucher, 2001.v. 4, p. 91-143.

ARAÚJO, F. B.; SILVA, P. H. A.; MINIM, V. P. R. Perfil sensorial e composição físicoquímica de cervejas provenientes de dois segmentos do mercado brasileiro. Ciência e Tecnologia de Alimentos, v.23, n.2, p.121-128, 2003

ASBC- Methods of Analyses of the American Society of Brewing Chemists. $8^{\text {th }}$ Revised Edition .Minnesota: The Technical Committee and the Editorial Committee of the ASBC, 1996.

BANDEIRA, R. D. C. C., Desenvolvimento e validação de metodologia na detecção e quantificação de Ocratoxina $A$ no café verde e torrado utilizando a técnica cromatografia líquida acoplada a espectrometria de massas aplicando os conceitos da metrologia química. 2010. 134 f. Tese (doutorado) - Programa de Pós-Graduação em Ciência e Tecnologia de Alimentos, Universidade Federal Rural do Rio de Janeiros, 2010. 
BATISTA, R.A. Produção e avaliação sensorial de cerveja com pinhão (Araucaria angustifólia). 2014. 108 f. Dissertação (Mestrado em Biotecnologia Industrial) - Escola de Engenharia de Lorena, Universidade de São Paulo, 2014.

BELTRAMELLI, M. Cervejas Brejas \& Birras :Um guia completo para desmistificar a bebida mais popular do Brasil. São Paulo, SP: Leya, 2012.

BRAGANÇA, G. G. F. Poder de mercado do café brasileiro nos EUA: abordagem via demanda residual. Disponível em:<http://epge.fgv.br/portal/arquivo/1755.pdf $>$. Acesso em 20 de abril 2014.

BRÁNYIK, T.; VICENTE, A.A.; CRUZ, J.M.M.; TEIXEIRA, J.A. Continuous primary fermentation of beer with yeast immobilized on spent grains - The effect of operational conditions. Journal of the American Society of Brewing Chemists, v. 62, p. 29-34, 2004a.

BRASIL. Decreto n. 6871, de 4 de junho de 2009.Regulamenta a lei ${ }^{\circ}{ }^{\circ} 8.918$, de 14 de julho de 1994, que dispõe sobre a padronização, a classificação, o registro, a inspeção e fiscalização de bebidas. Diário Oficial da União. Brasília, D. F. , 05 jun. 2009. Disponível em: <http: //www.planalto.gov.br/ccivil_03/_Ato20072010/2009/Decreto/D6871.htm>Acesso em : 17 maio 2014.

BRIGGS, D. E. et al. Chemical and physical properties of beer. In: BRIGGS, D. E. et al. Brewing: science and practice. Cambridge: Woodhead, 2004 chap. 19, p. 662-712.

BRUNELLI, L. T. Produção de cerveja com mel: características físico-quimicas, energética e sensorial. Dissertação (mestrado). Universidade Estadual Paulista "Júlio Mesquita Filho". 2012. p 103. Botucatu

CAMPANHA, F. G. , DIAS, R. C. E, BENASSI, M. T. Discrimination of coffee species using Kahweol and cafestol: effects of roasting and of defects. Coffee Science, 5, 87-96, 2010 .

CARDOSO, J. M. P.; BATTOCHIO, J. R.; CARDELlO, H. M. A. B., Equivalência de dulçor e poder edulcorante de edulcorantes em função da temperatura de consumo em bebidas preparadas com chá-mate em pó solúvel. Ciência Tecnologia de Alimentos, v. 24, n.3, p. 448-452, 2004.

CARVALHO, G. B. M. Obtenção de cerveja usando banana como adjunto e aromatizante.2009.163f.Tese (Doutorado em Biotecnologia Industrial), Universidade de São Paulo, Lorena - SP

CARVALHO, G. B. M.; SILVA, D. P.;TEIXEIRA, J. A.; ALMEIDA E SILVA, J. B. Cerveja a partir de banana como adjunto do malte. In: Venturini Filho, G. W. Ciência e Tecnologia de Bebidas. São Paulo: Edgar Blucher, 2009.

CARVAlHO, J. et al. Análise do Perfil de Compra do Consumidor de Cerveja Pilsen Branca. Rio's International Journal on Sciences of Industrial and Systems Engineering and Management, v. 2, 2008. Disponível em: < http:// www.rij.eng.uerj.br/research/2008/rm083-01.pdf>. Acesso em: 19 jun 2015. 
CLARKE, R. J. MACRAE, R. Green coffee, roast and ground. In: Encyclopedia of Food Sciences and Nutrition. CABALLERO, B., TRUGO, L. C., FINGLAS, P. (Ed.), $2^{\text {nd }}$ ed.Oxford: Academic Press, 2003 v. 3, 1486-1489 p.

ClEMENTE, A.; PASSARELli,E.; PINHO, F. G. A vez das pequenas. Prazeres da mesa, a bíblia da gastronomia. São Paulo, n. 126. p. 34-43, 2014.

COLE, M. Vamos falar de cerveja: um guia completo. São Paulo; Editora Marco Zero,. 2012.

COMPTON, J. Beer quality and taste methodology. In: BRODERICK, H.M. (Ed.) The practical brewer : a manual for the brewing industry. 2 nd. Ed. Madison: Impressions, 1978. Cap. 15 , p. 288-308.

CONFENAR. Consumo de cerveja cresce entre mulheres. Revista Confenar, v. 5, n. 29, p. 36-38, 2009a. Disponível em: http://www.confenar.com.br/comunicacao/revista/29/. Acesso em: 7 julho 2015.

CRUZ, J. M. M. Cerveja. In: FONSECA, M. M.; TEIXEIRA, J. A. Reactores biológicos. Lisboa/Porto: Lidel, 2007. p. 277-305.

CURI, R.A. Produção de cerveja utilizando cevada como adjunto de malte. 2006. 110f. Tese (Doutorado em Agronomia/ Energia na Agricultura) - Faculdade de Ciências Agronômicas, Universidade Estadual Paulista. Botucatu.

DAMODARAN, S.; PARKIN, K. L.; FENNEMA, O. R. Química de alimentos de Fennema. 4. ed. Porto Alegre: Artmed, 2010. 900 p.

DRAGONE, G.; Fermentação primária para produção de cervejas de altas densidades por processo contínuo utilizando leveduras imobilizadas em bagaço de malte. 2007.140 f. Tese (Doutorado em Biotecnologia Industrial) - Escola de Engenharia de Lorena, Universidade de São Paulo, Lorena, 2007.

DRAGONE, G.; ALMEIDA E SILVA, J. B. Cerveja. In: VENTURINI FILHO, W. G. Bebidas alcoólicas: ciência e tecnologia, São Paulo: Editora Blucher, 2010.

DRAGONE, G.; SILVA, D. P.; ALMEIDA E SILVA, J. B.; LIMA, U. A. Improvement of the ethanol productivity in a high gravity brewing at pilot plant scale. Biotechnology Letters, v. 25, p. 1171-1174, 2003.

ESSLINGER, H. M.; NARZISS, L. Beer.In: ULLMANN'S encyclopedia of industrial chemistry. Freiberg; Sachsen,2009.

EBC. Analytical European Brewery Convention, 2005.

FLAMENT, I. Coffee flavor chemistry. New York: John Wiley \& Sons, Ltd., 2002. 410 p.

GONÇALVES, D. Indústria de insumos trabalha pesado para garantir diversidade de sucos. Revista Engarrafador Moderno, n. 185, p. 20-24, 2009b. Disponível em: <http:// www.engarrafadormoderno.com.br/edicoes/Edi\%E7\%E3o_185.pdf >. Acesso em 19 maio 2015. 
GOODE, D. L.; ARENDT, E. K. Pilot scale production of a lager beer from a grist containing 50\% unmalted sorghum. Journal of the Institute of Brewing, v. 109, p. 208217, 2003.

HARDWICK, W. A. The properties of beer. In: HARDWICK, W. A.(Ed.). Handbook of brewing. New York: Marcel Dekker, 1995. Cap.19, p.551-585.

HENDGES, D. H. Produção de cervejas com teor reduzido de etanol, contendo quinoa malteada como adjunto. 2014. 93 f. Tese (Doutorado em Biotecnologia Industrial), Universidade de São Paulo, Lorena - SP.

HORNSEY I. S. Elaboración de cerveza. Microbiologia, bioquimica y tecnologia. Zaragoza: Editora Acribia, 2003. 229 p.

HOUGH, J. S. Biotechnology of malting and brewing. Cambridge: Cambridge University Press, 1985. p. 159

HOUGH, J. S. Biotecnologia de la cerveza y de la malta. Zaragoza: Editorial Acribia,1990. 194 p.

ICO - International Coffee Organization. Exports by exporting countries to all destinations. Dezembro, 2011.Disponível em < http: //www.ico.org/prices/m1.htm> Acesso em 13 abril 2014.

ILLY, E. A saborosa complexidade do café, a ciência que está por trás de um dos prazeres simples da vida. Scientific American Brasil, n. 2, jul. 2002.

INSTITUTO ADOLFO LUTZ (São Paulo). Métodos físico-químicos para análise de alimentos/coordenadores Odair Zenebon, Neus Sadocco Pascuet e Paulo Tiglea - São Paulo: Instituto Adolfo Lutz, 2008, Cap.6

JAEGER, S. R. Non-sensory factors in sensory Science research. Food Quality and Preference, v.17, n.1-2, p.132-144, 2006. Disponível em: <http:// www.elsevier.com/locate/foodqual>.Acesso em: 9 jun. 2015.

KEUKELEIRE, D. Fundamentals of beer and hop chemistry. Química Nova, v.23, n.1, p.108-112, 2000.

KOTLER, P. KELLER, K. L. Administração de marketing. 12. ed. São Paulo: Pearson Prentice Hall,2006.

KREISZ, S. Malting. In: EßLINGER, H. M. Handbook of brewing. Weinheim, Germany: WILEY- VCH, 2009. P. 147-164

KRISTIANSEN, A. G. The Balling formula - origin. Scandinavian brewers review, 2007, 64.4: $24 . \quad$ Disponível em: <http://kwantum.biz/sites/default/files/plato\%20balling.pdf> Acesso em 9 jul. 2015

KUNZE, W. Technology of brewing and malting: Berlin: VLB, 1996. 726 p. 
LINKO, M.; HAIKARA, A.; RITALA, A.; PENTTILA, M. Recent advances in the malting and brewing industry. Journal of Biotechnology, n. 65, p. 85-98, 1998.

LIMA, U. A. Bebidas estimulantes.In: VENTURINI FILHO, W. G. Bebidas não alcoólicas: ciência e tecnologia, São Paulo: Editora Blucher, 2010. v. 2.

LIMA, U. A. Matérias-primas dos alimentos. São Paulo: Editora Blucher, 2010.

LOPES, L.M.V. Avaliação da qualidade de grãos crus e torrados de cultivares de cafeeiro (Coffea arabica L.). 2000. 95 p. Dissertação (Mestrado em Ciência dos Alimentos) Universidade Federal de Lavras, Lavras, 2000.

MARTÍNEZ, O. Obtenção de cerveja super concentrada com a utilização de xarope de milho como adjunto do malte. 2014. 144 p. Dissertação (Mestrado em Biotecnologia Industrial) - Escola de Engenharia de Lorena, Universidade de São Paulo, Lorena, São Paulo, 2014.

MATOS, D. A.; SANTOS, I. J.; COIMBRA, J. S. R.; SILVA, P. H. A. Fécula de batata como adjunto de malte na fabricação de cerveja. Boletim Centro de Pesquisa de Processamento de Alimentos, v. 23, n. 1, p. 161-172. 2005.

MEILGAARD, M. Composición del mosto. In: KLIMOVITZ, R. El cervecero en la práctica. $3^{\text {rd }}$ ed. Minnesota: Master Brewers Association of Americas, 2002.

MEUSSDOERFFER, F.; ZARNKOW, M. Starchy Raw Material. In: EßLINGER, H. M. Handbook of Brewing. Weinheim, Germany: WILEY- VHC ,2009. p. 43-84

MINIM,V.P.R. Análise sensorial: estudos com consumidores. Viçosa: Editora UFV, 2013. $332 \mathrm{p}$.

MORADO, R. Larousse da cerveja.São Paulo, SP :Larousse,2009.p.20-338

MORAIS, S. A. L.; AQUINO, F. J. T.; NASCIMENTO. P. M.; NASCIMENTO, E. A.; CHANG R.; Compostos bioativos e atividade antioxidante do café conilon submetido a diferentes graus de torra.Química Nova, 32, 327-331,2009.

MOWEN, J. C.; MINOR, M.S. Comportamento do consumidor. São Paulo: Prentice Hall, 2003.

NASCIMENTO, E. A.; AQUINO, F.J.T.; NASCIMENTO, P. M.; CHANG, R.; MORAIS, S. A. L.; Composição química do café conilon em diferentes graus de torrefação. Ciência e Engenharia, v. 16, n. 1/2, p. 17 - 21, jan. - dez. 2007

NAVA, J. N. Cacao, café y té. Barcelona: Salvat, 1953. 687 p.

OETTERER, M., REGITANO-D'ARCE, M.A.B., SPOTO, M. H. F. Fundamentos de ciência e tecnologia de alimentos. Barueri, SP :Manole,2006. p. 51-98.

ROS, J. Estabilidad coloidal de la cerveza. Pamplona (Espanha): Laboratorio Industrial de Bioquímica S.A. (L.I.B.S.A), 1980. 83 p. 
ROSA, S. E. S. da; COSENZA, J. P.; LEÃO, L. T. de S. Panorama do setor de bebidas no Brasil. BNDES Setorial, n. 23, p. 101-150, 2006.

ROSSETTI, R.P. Determinação de fenóis totais em frutos do café: Avaliações em diferentes fases de maturação. 2007.72f. Dissertação (Mestrado em Ciências) Universidade de São Paulo. São Carlos.

RUSSELL, I. Yeast. In : PRIEST, F. G.; STEWART, G. G. Handbook of brewing. $2^{\text {nd }}$ ed. Boca Raton: Taylor \& Francis, 2006. 853 p.

SANTOS, C. D. O. Avaliação do emprego do arroz preto (Oryza Sativa L.) submetido à hidrólise enzimática como adjunto na fabricação de cerveja. 2011. 75 f. Dissertação (Mestrado em Biotecnologia Industrial),Universidade de São Paulo, Lorena - SP

SANTOS, I. J. Cinêtica de fermentações e estudo de metabólitos e enzimas intracelulares envolvidas na fermentação alcoólica cervejeira conduzidas com leveduras de alta e baixa fermentação em diferentes composições de mosto. 2005. 139 f. Tese (Doutorado em Ciência e Tecnologia de Alimentos), Universidade Federal de Viçosa, Viçosa-MG.

SANTOS, H. L. Ánalise dos hábitos dos consumidores de cerveja em Porto Alegre/RS e comparação entre os gêneros. Porto Alegre: UFRGS, 2008. 64 p.

SARRAZIN, C.; LEQUÉRE, J. L.; GRETSCH. C.; LIARDON, R. Representativeness of coffee aroma extracts: a comparison of different extraction methods, Food Chemistry, v.70, p.99-106, 2000.

SILVA, J.B.A. Cerveja.In: VENTURINI FILHO, W. G. (Coord.).Tecnologia de Bebidas.São Paulo: Edgard Blucher, 2005.p.347-356.

SINDICERV - Sindicato Nacional da Indústria da Cerveja. Atuação. Disponível em : <http://www.sindicerv.com.br/atuacao.php> Acesso em: 26 março 2014.

SINDICERV. Sindicato Nacional da Indústria da Cerveja. Mercado. Disponível em: http://www.sindicerv.com.br/mercado.php. Acesso em: 19 jun 2015.

SIVETZ M.; DEROSIER, N.W. Coffee technology. Westport: The AVI Publishing Co., 1979 p. 307-347.

SIVETZ, M.; FOOTE, H. E. Bebidas: tecnología, química y microbiología. Zaragoza: Acribia S. A., 1997. 198p.

SOHRABVANDI, S. et al. Alcohol-free beer: methods of production, sensorial defects and healthful effects. Food Reviews International, v. 26, p. 335-352, 2010.

SOUZA, R. A. M. Mudanças no consumo e na distribuição de alimentos: o caso da distribuição de hortaliças de folhas na cidade de São Paulo. 2005. 150 p. Dissertação (Mestraso em Economia) - Instituto de Economia, Universidade Estadual de Campinas, Campinas - SP, 2005. 
STEWART, G.G. A Brewer's Delight. Chemistry and Industry, p. 706-709, nov. 2000.

TAYLOR, D. G. Water. In: PRIEST, F. G.; STEWART, G. G. Handbook of brewing. $2^{\text {nd }}$ ed. Boca Raton : Taylor \& Francis, 2006. 853 p.

TSCHOPE, E.C. Microcervejarias e cervejarias. A história, a arte e a tecnologia.São Paulo: Editora Aden, 2001.p. 1-221.

VARNAM, A. H.; SUTHERLAND, J. P. Bebidas. Espanha: Acribia, 1997. 487p.

VENTURINI FILHO,W. G.; CEREDA, M. P. Hidrolisado de fécula de mandioca como adjunto de malte na fabricação de cerveja: avaliação química e sensorial. Ciência e Tecnologia de alimentos, v. 18, n. 2, p. 156-164, 1998.

VENTURINI FILHO, W. G., (coord.). Bebidas alcoólicas: ciência e tecnologia. São Paulo,Editora Blucher, 2010. 461p.

VENTURINI FILHO, W. G., (coord.). Indústria de bebidas: inovação, gestão e produção, São Paulo, Editora Blucher, 2011. 536 p.

VILAS BOAS, L. H. B. Comportamento do consumidor de produtos orgânicos: uma análise na perspectiva da teoria da cadeia de meios e fins. 2005. 222f. Tese (Doutorado em Administração) - DAE, Universidade Federal de Lavras, Lavras MG.

WILLAERT, R.; NEDOVIC, V. A. Primary beer fermentation by immobilized yeast - a review on flavour formation and control strategies. Journal of Chemical Technology and Biotechnology, v.81, n.8, p.1353-1367, 2006.

WYLER, P. Influência da madeira de carvalho na qualidade da cerveja. $2013.92 \mathrm{f}$. Dissertação (Mestrado em Ciência e Tecnologia de Alimentos), Universidade de São Paulo, Piracicaba- SP. 


\section{Apêndice A - Questionário aplicado para a pesquisa mercadológica}

\section{Questionário}

Nome:

Sexo: ( ) Masculino ( ) Feminino

Estado civil

( ) Solteiro

( ) Namorando

( ) Casado/União estável

( ) Divorciado

( ) Viúvo

Escolaridade

( ) 1ㅇ Grau

( ) 2 o Grau

() Superior

( ) Pós- Graduação

Qual bebida alcoólica é a sua preferida?

() Vinho

() Vodka

( ) Whisky

( ) Cerveja

() Outra.

Qual?

Com que frequência você consome cerveja?

() Diariamente

() 2 a 3 vezes por semana

() 1 vez por semana

( ) a cada 15 dias

( ) uma vez por mês

Em que local você prefere consumir cervejas?
() Bares
( ) Festas/baladas/churrascos

( ) na casa de amigos

() Restaurantes

( ) na sua própria casa

Na sua opinião, quais os três itens mais importantes para o consumo de cerveja? Enumere de 1 a 3, considerando o 1 como mais importante.

( ) Sabor

() Preço

() Marca

( ) Efeito do álcool

( ) meus amigos e familiares consomem

Você já consumiu cerveja artesanal?

( ) já consumiu e gostou

( ) já consumiu e não gostou

( ) Não consumiu e gostaria de experimentar

( ) Não consumiu e não gostaria de experimentar

( ) não sabe o que é cerveja artesanal

Qual a sua preferência quanto ao tipo de cerveja?

( ) Pilsen ( cerveja tipo Skol, Brahma, etc)

( ) IPA (cerveja bem amarga)

( ) Weissbier ( cerveja de trigo)

( ) Porter (cerveja escura tipo Guinness)

() Outra. Qual?

Quanto ao sabor da cerveja, você nota diferença de sabor entre as marcas de um mesmo tipo de cerveja?

( ) Sim ( ) Não

Quando você toma uma cerveja, qual dos 3 atributos você dá mais importância? Enumere de 1 a 3, considerando o 1 como mais importante.
() Sabor
( ) Aroma
( ) Teor alcoólico 
( ) Amargor

( ) Doçura

Você já tomou alguma cerveja com café?

( ) Sim ( ) Não

Se você respondeu sim:

Você gostou? ( ) Sim ( ) Não

Tem alguma marca preferida de cerveja

com

café?Qual? 


\section{Apêndice B - Gráficos de Fermentação}

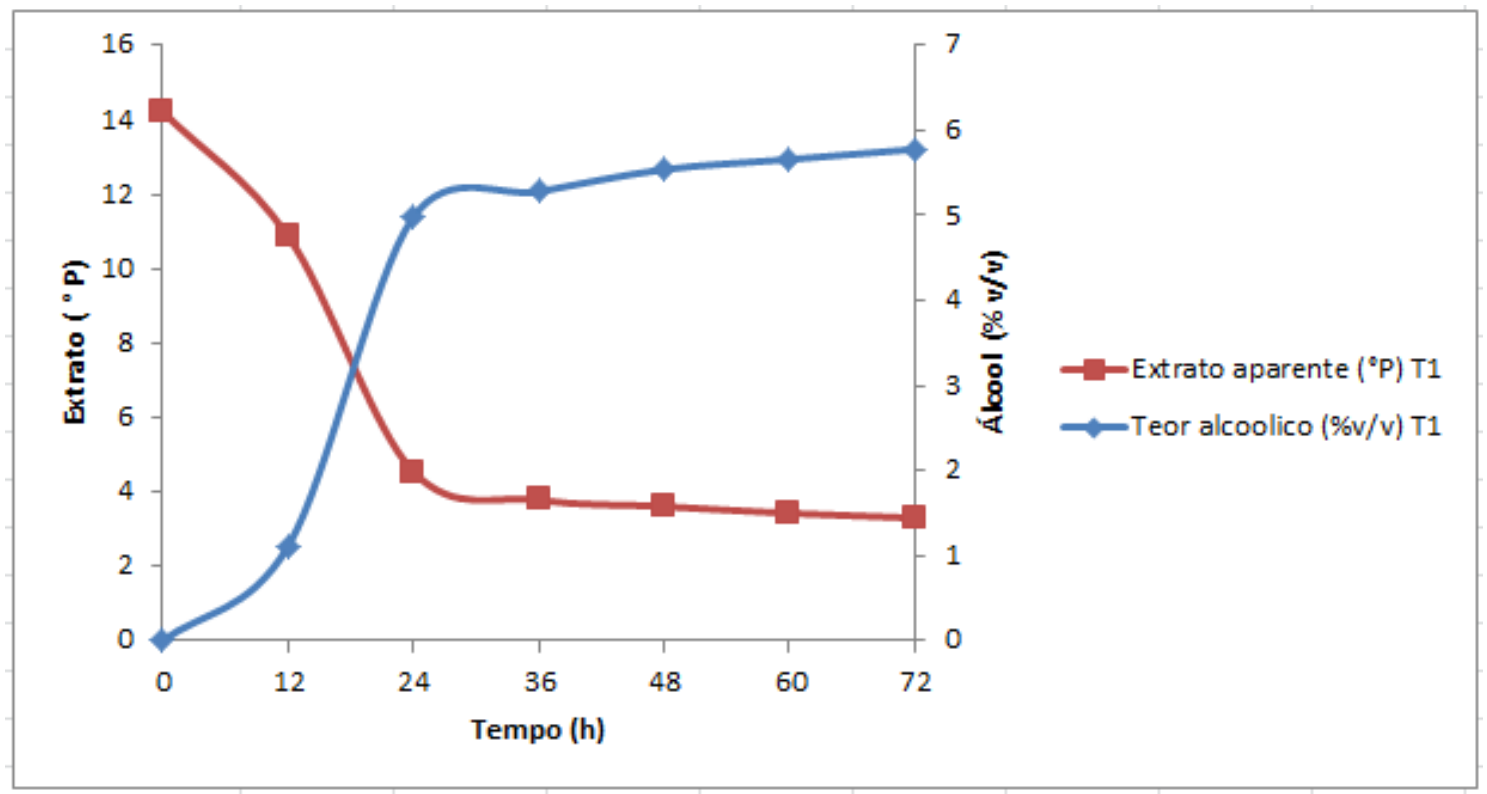

Figura B1. Perfil do consumo de açúcares e produção de álcool para a cerveja sem café identificada como Tratamento 1 .

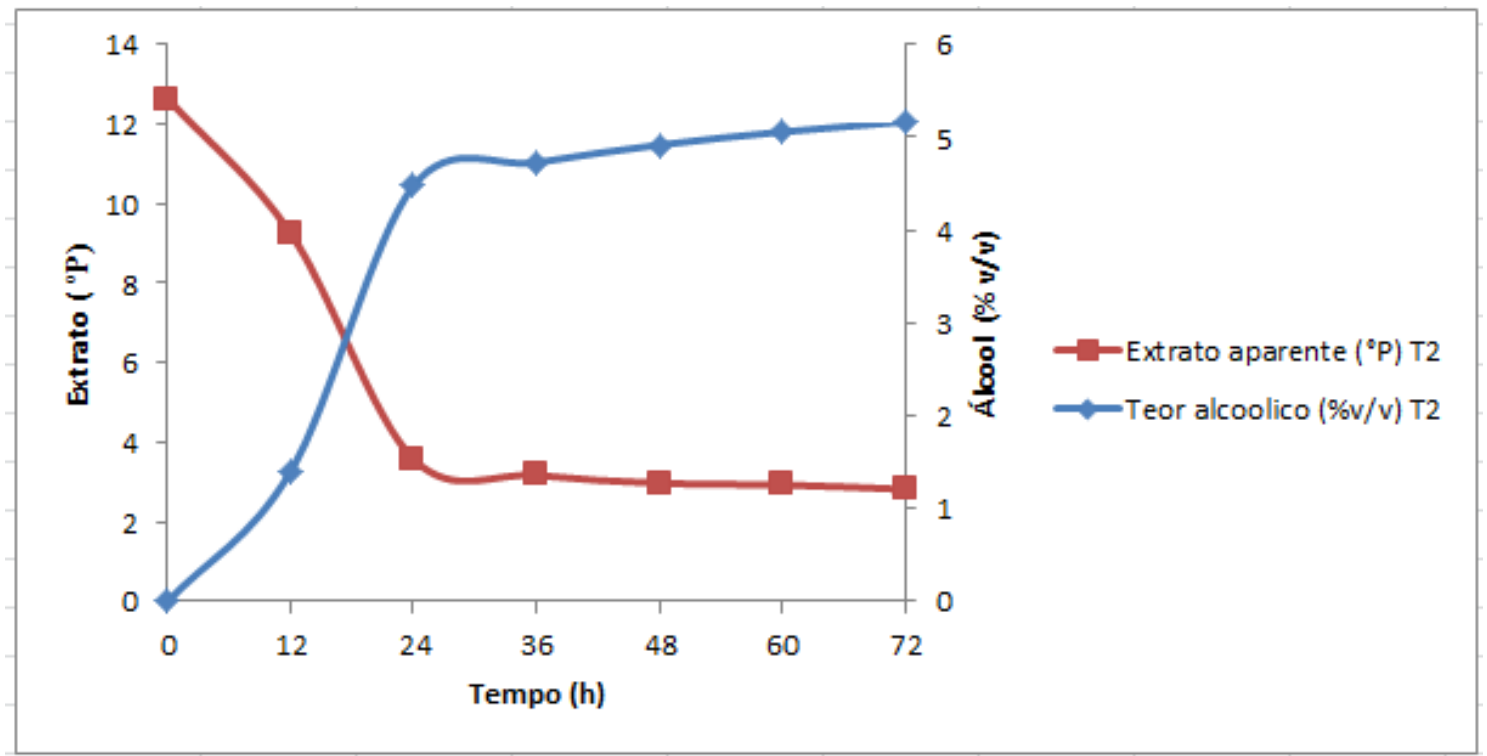

Figura B2. Perfil do consumo de açúcares e produção de álcool para a cerveja com $15 \%$ de café identificada como Tratamento 2. 


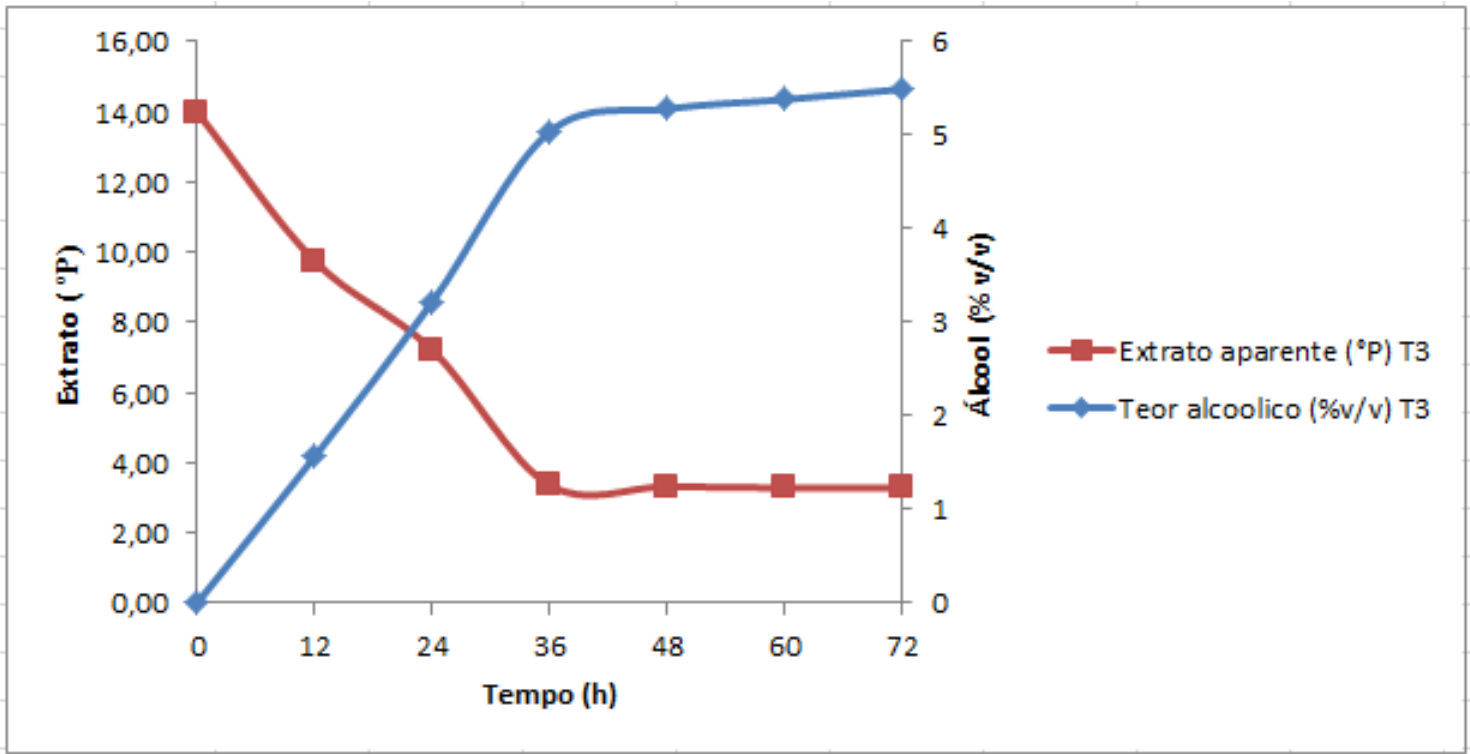

FiguraB3. Perfil do consumo de açúcares e produção de álcool para a cerveja com $25 \%$ de café identificada como Tratamento 3 .

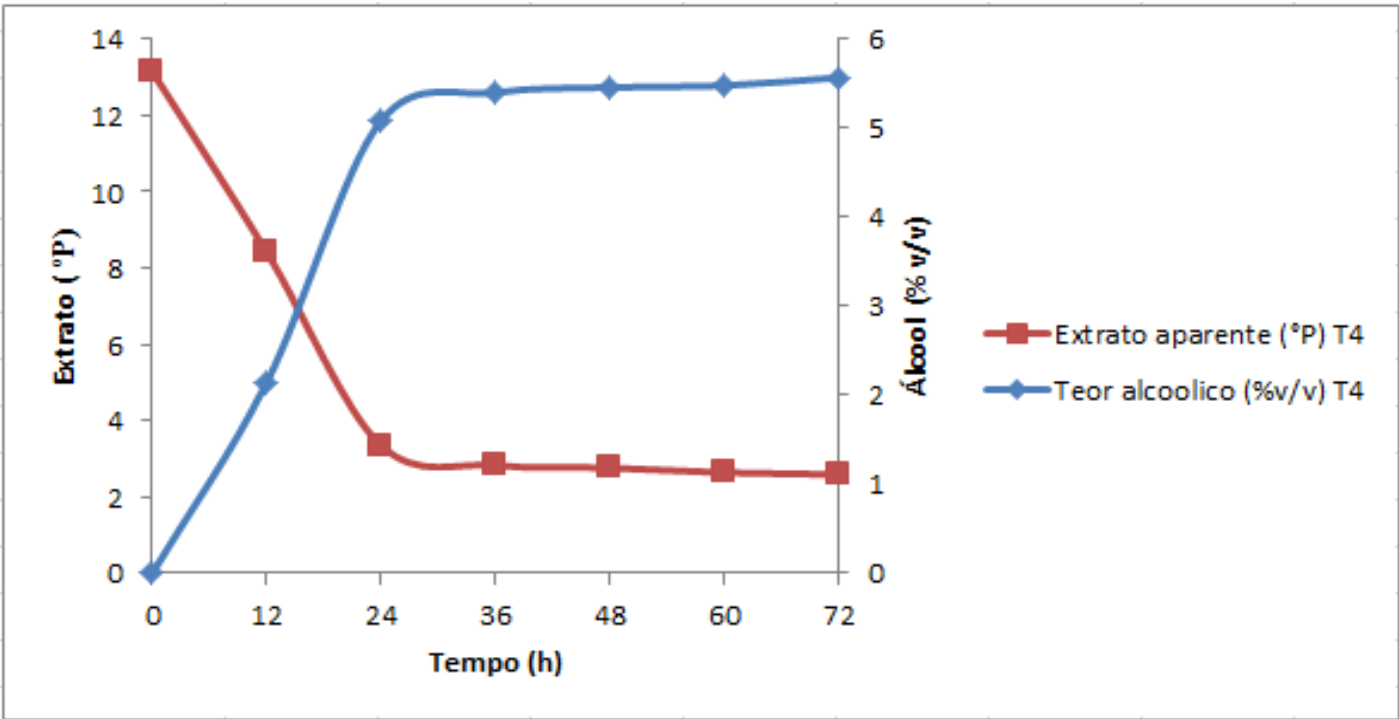

Figura B4. Perfil do consumo de açúcares e produção de álcool para a cerveja com 35\% de café identificada como Tratamento 4. 


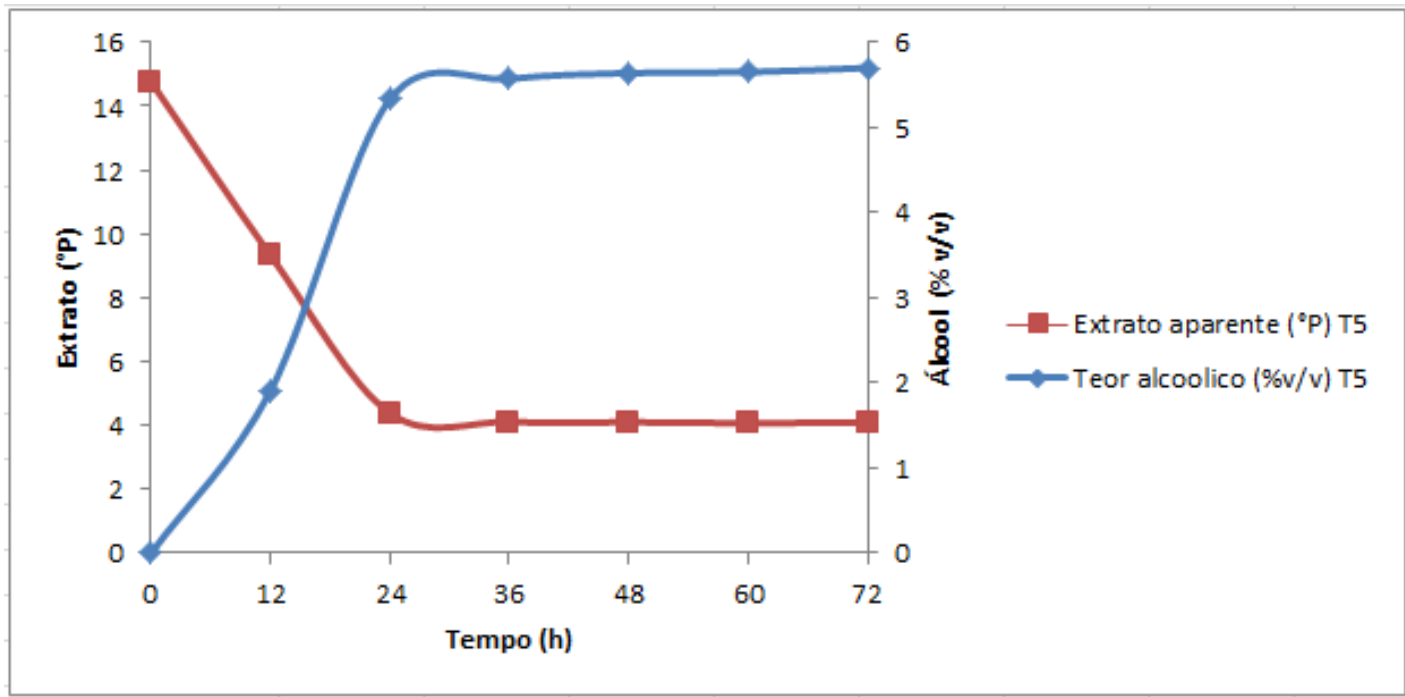

Figura B5. Perfil do consumo de açúcares e produção de álcool para a cerveja com $45 \%$ de café identificada como Tratamento 5.

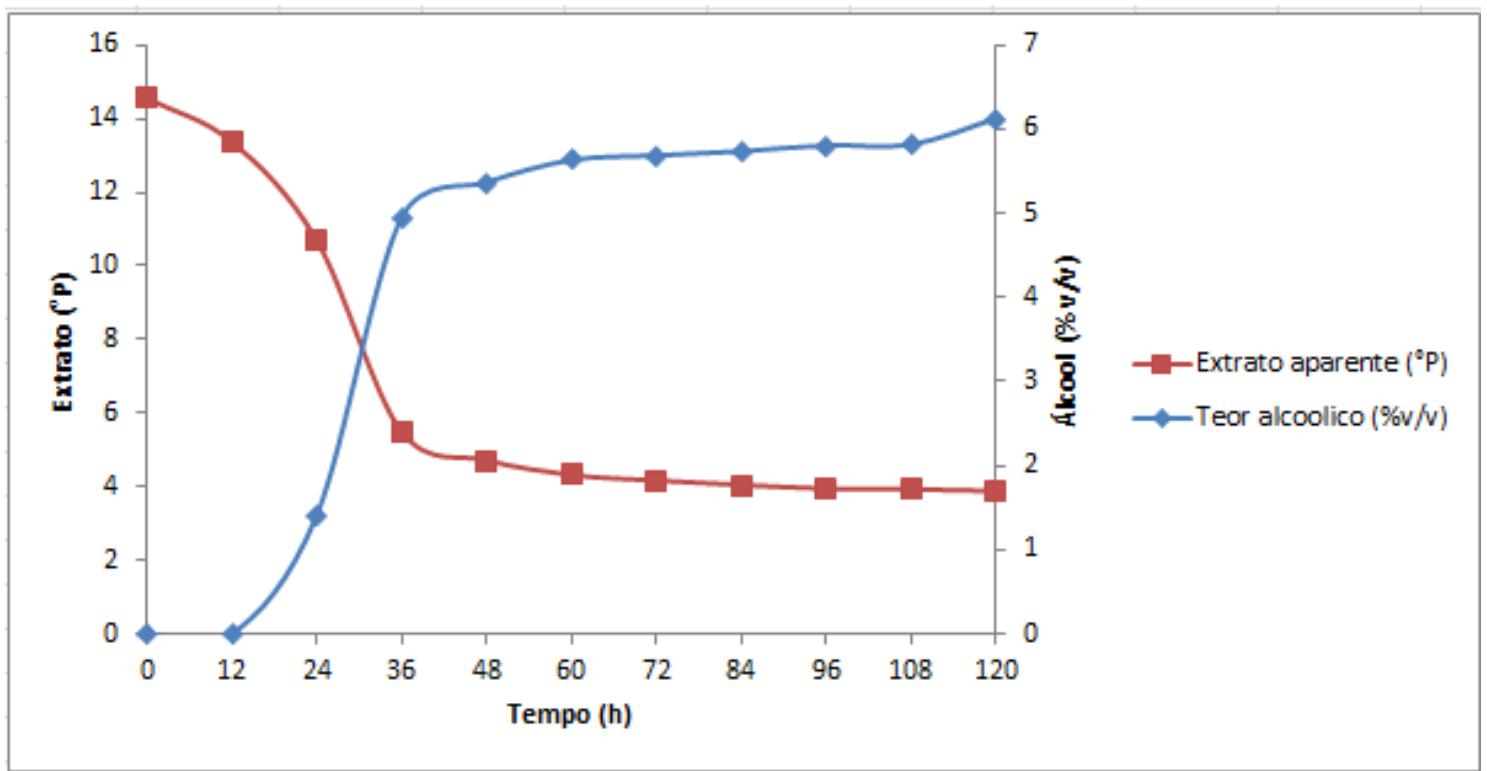

Figura B6. Perfil do consumo de açúcares e produção de álcool para a cerveja produzida em escala piloto ( cerveja aromatizada com $45 \%$ de café). 


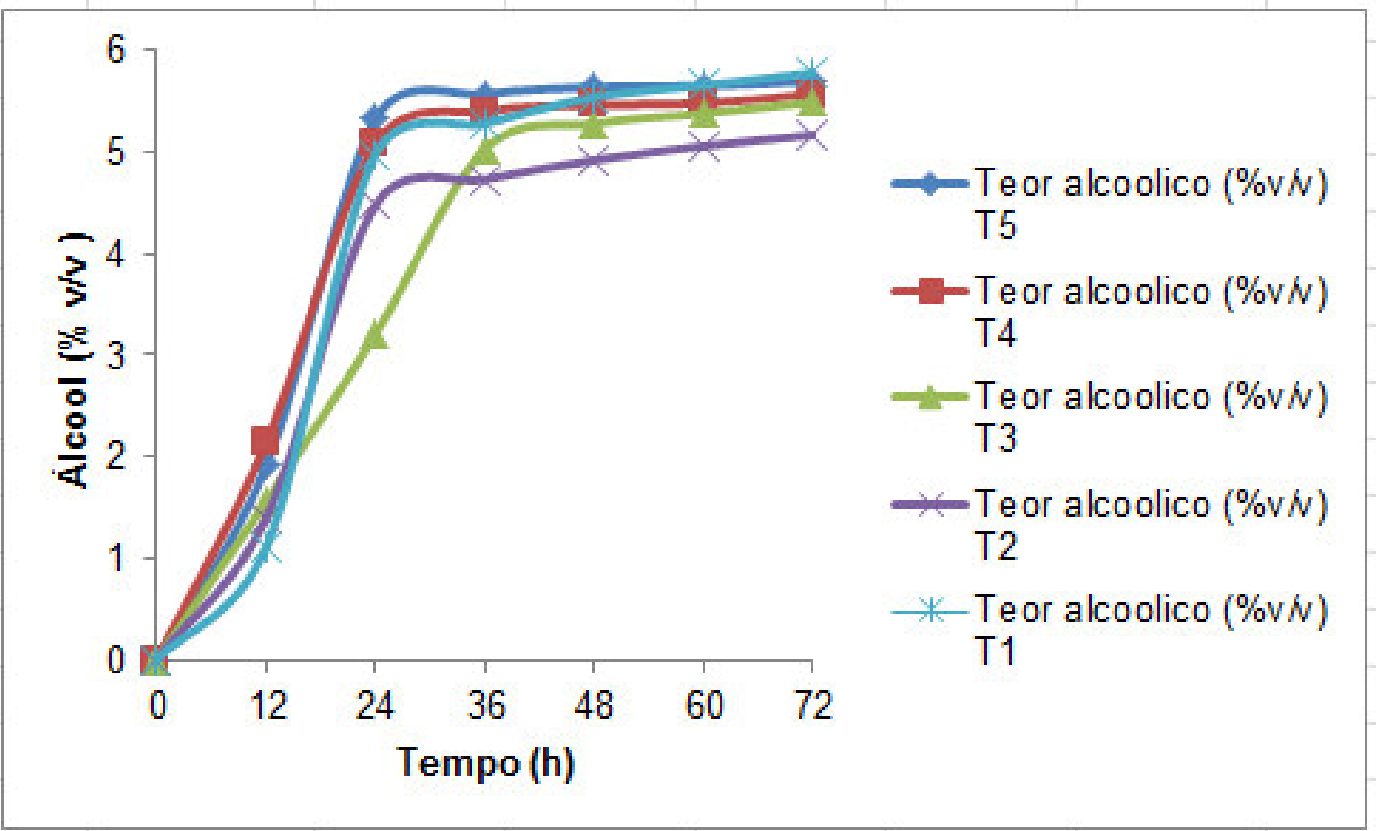

Figura B7. Gráfico comparativo do perfil da produção de álcool com as 5 fermentações, com diferentes proporções de café.

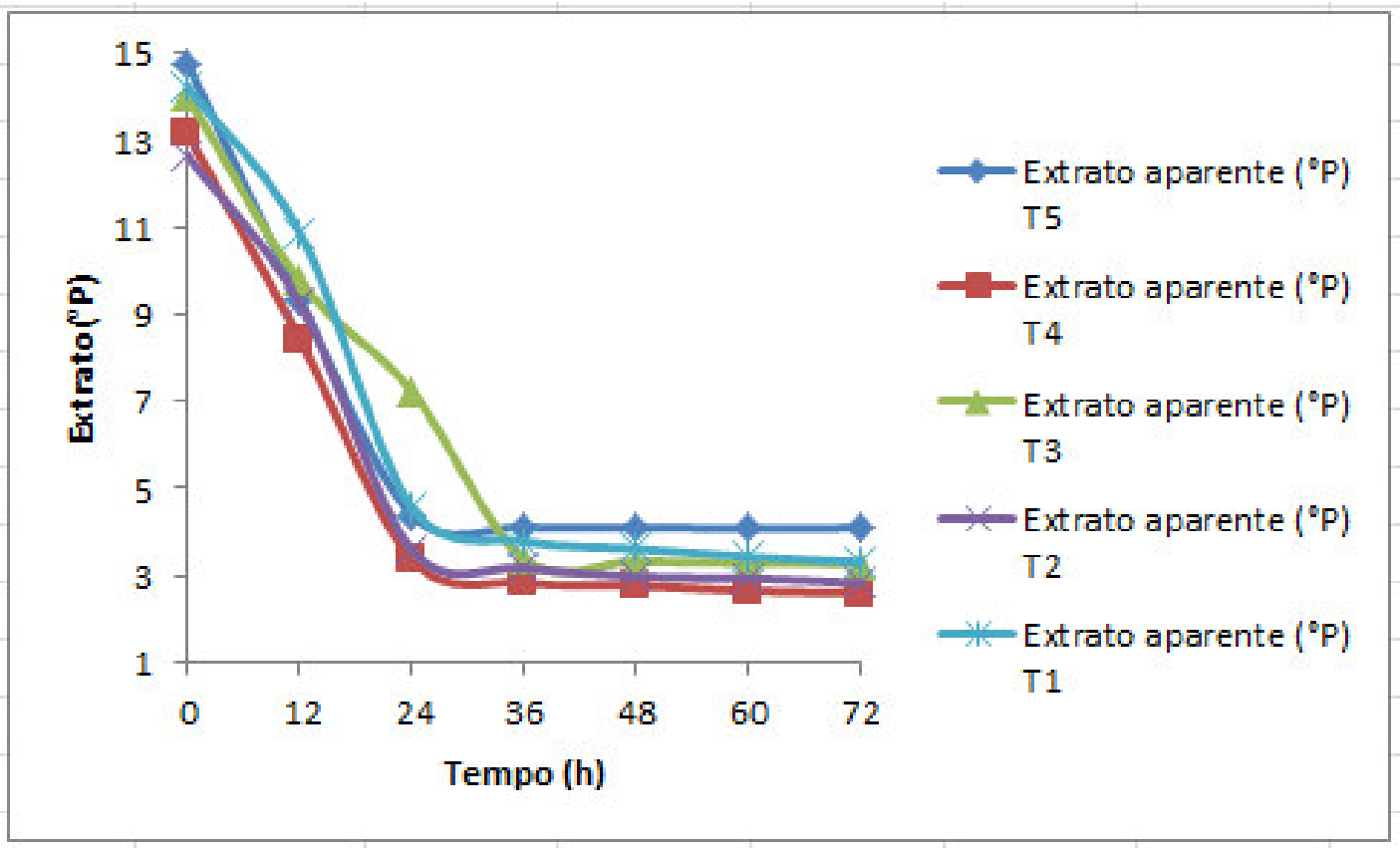

Figura B8. Gráfico comparativo do perfil de consumo de açúcares com as 5 fermentações. 


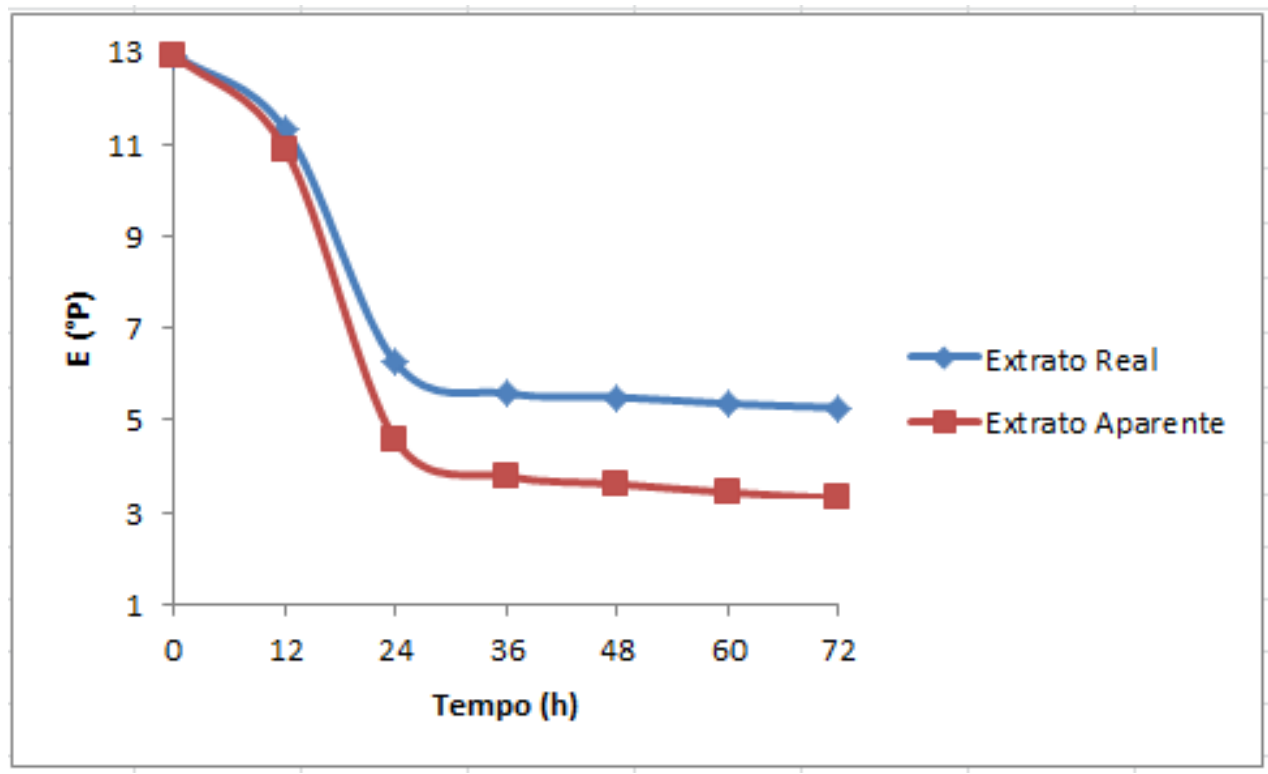

Figura B9. Relação entre extrato Real e Aparente para a cerveja obtida com o Tratamento 1.

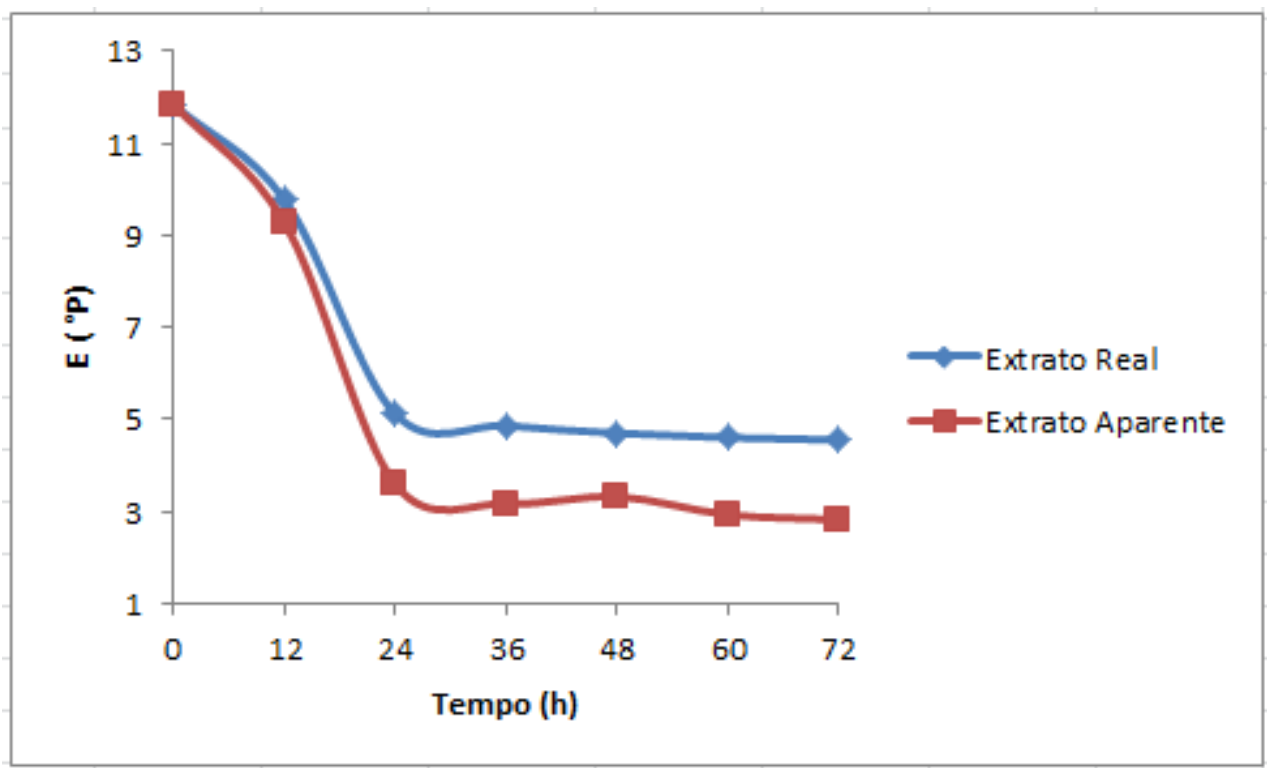

Figura B10. Relação entre extrato Real e Aparente para a cerveja obtida com o Tratamento 2. 


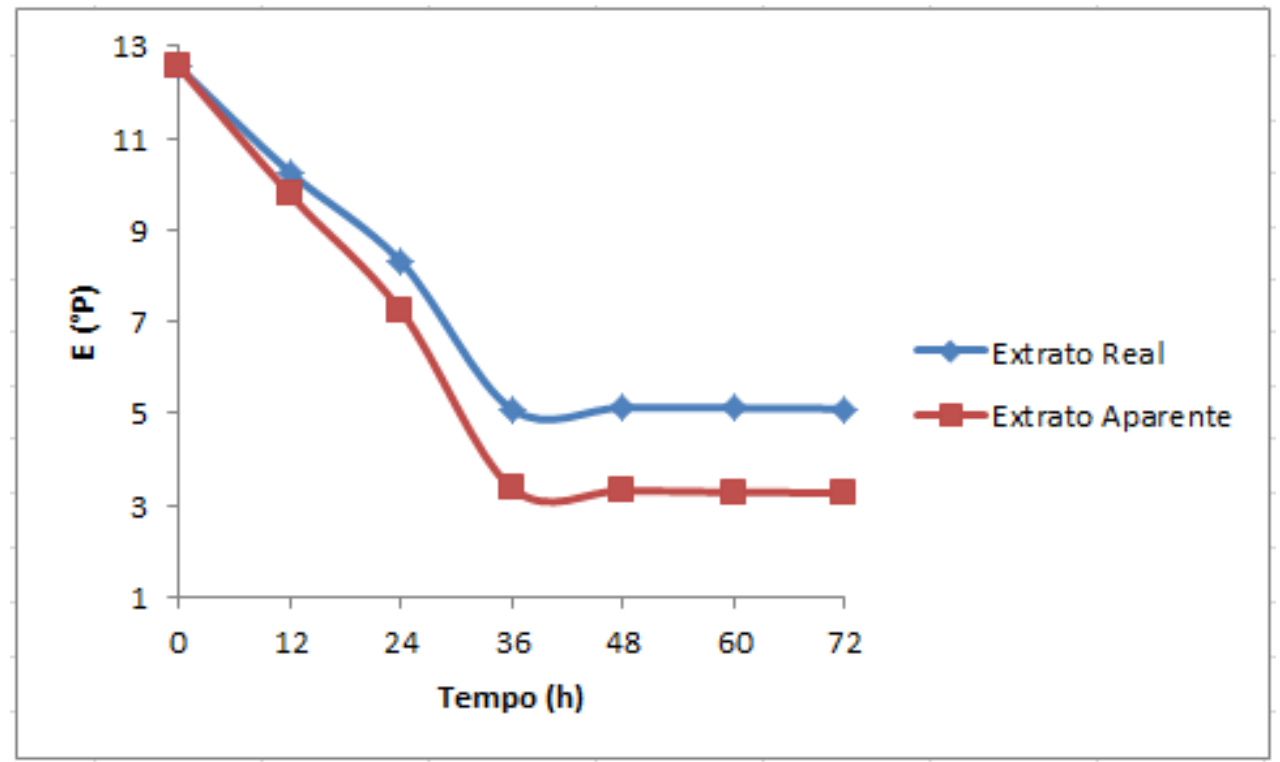

Figura B11. Relação entre extrato Real e Aparente para a cerveja obtida com o Tratamento 3.

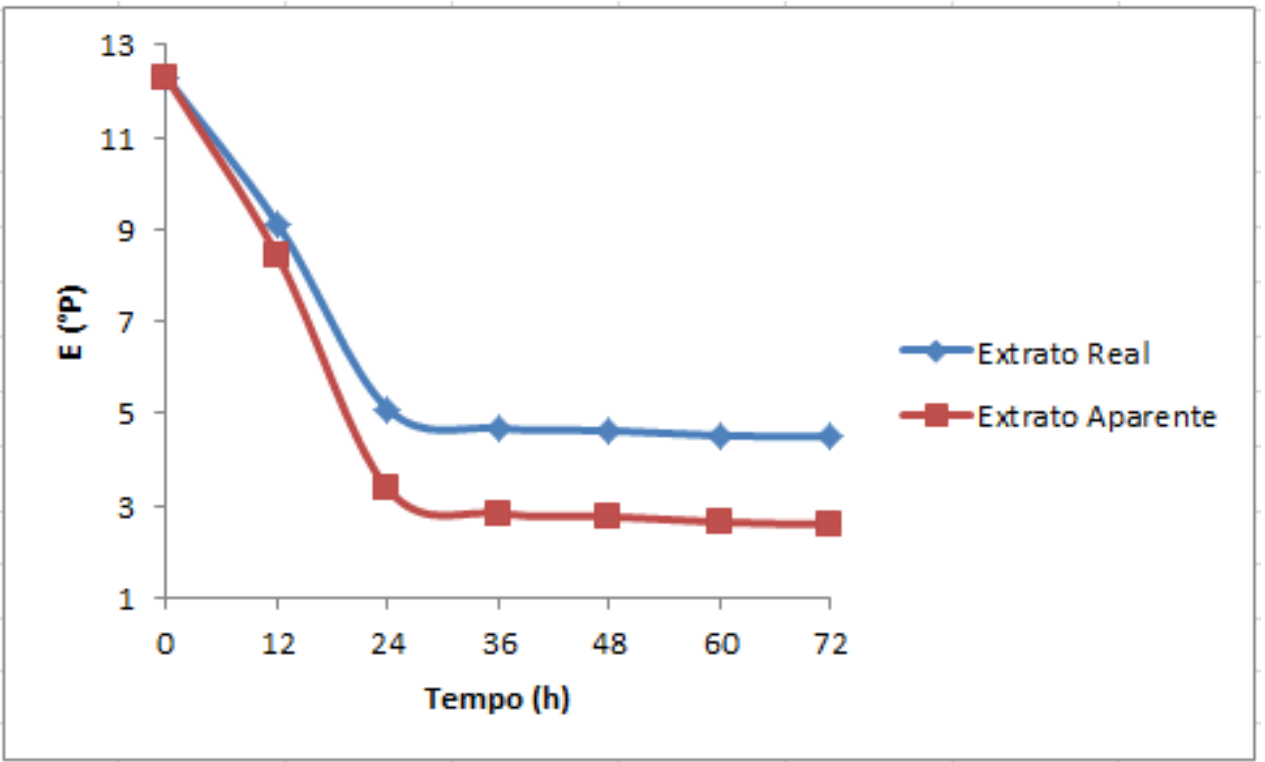

Figura B12. Relação entre extrato Real e Aparente para a cerveja obtida com o Tratamento 4. 


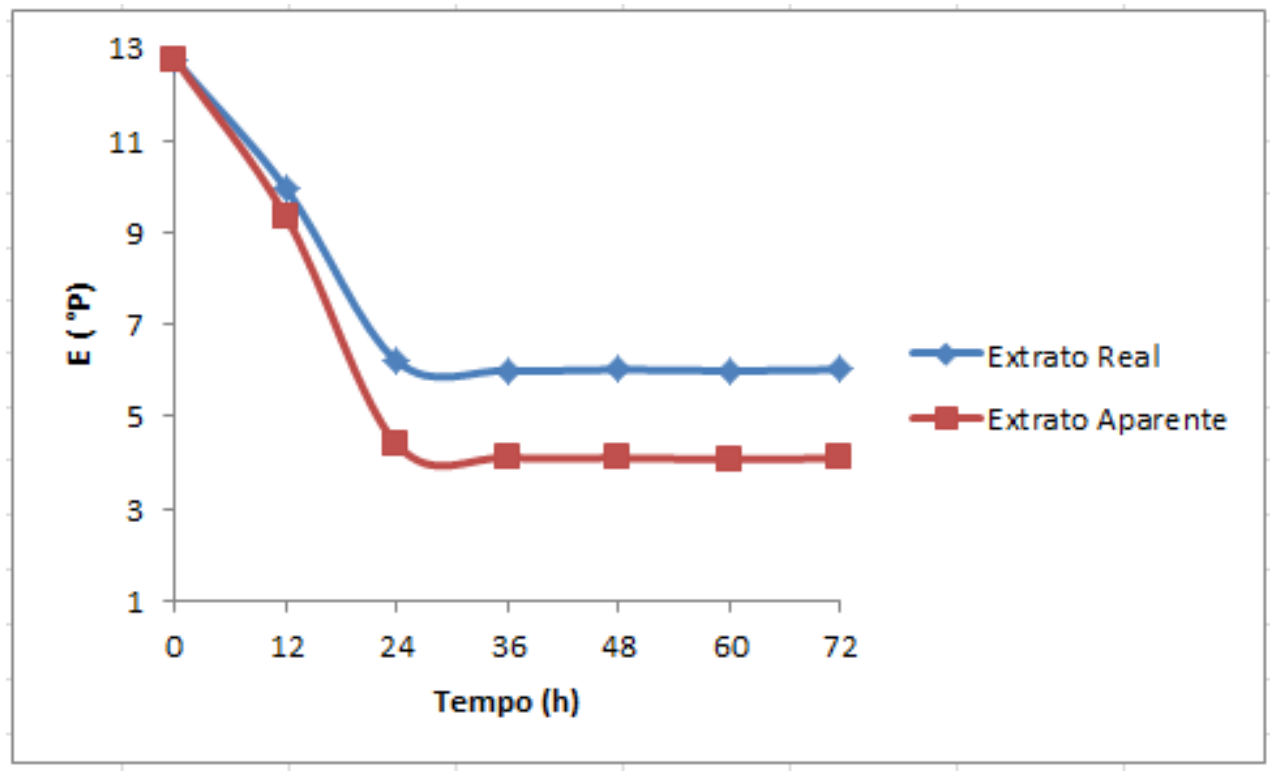

Figura B13. Relação entre extrato Real e Aparente para a cerveja obtida com o Tratamento 5.

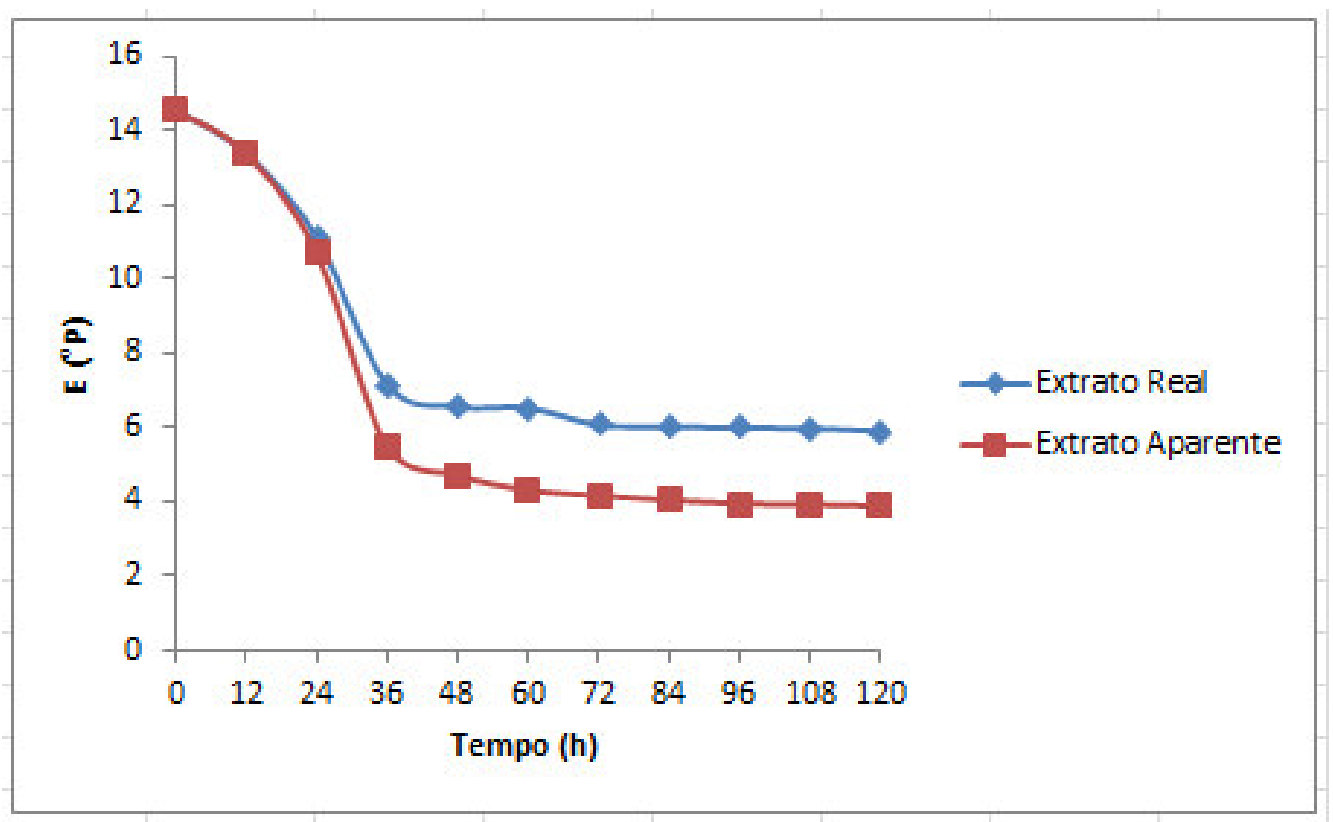

Figura B14. Relação entre extrato Real e Aparente para a cerveja que foi produzida em escala piloto. 


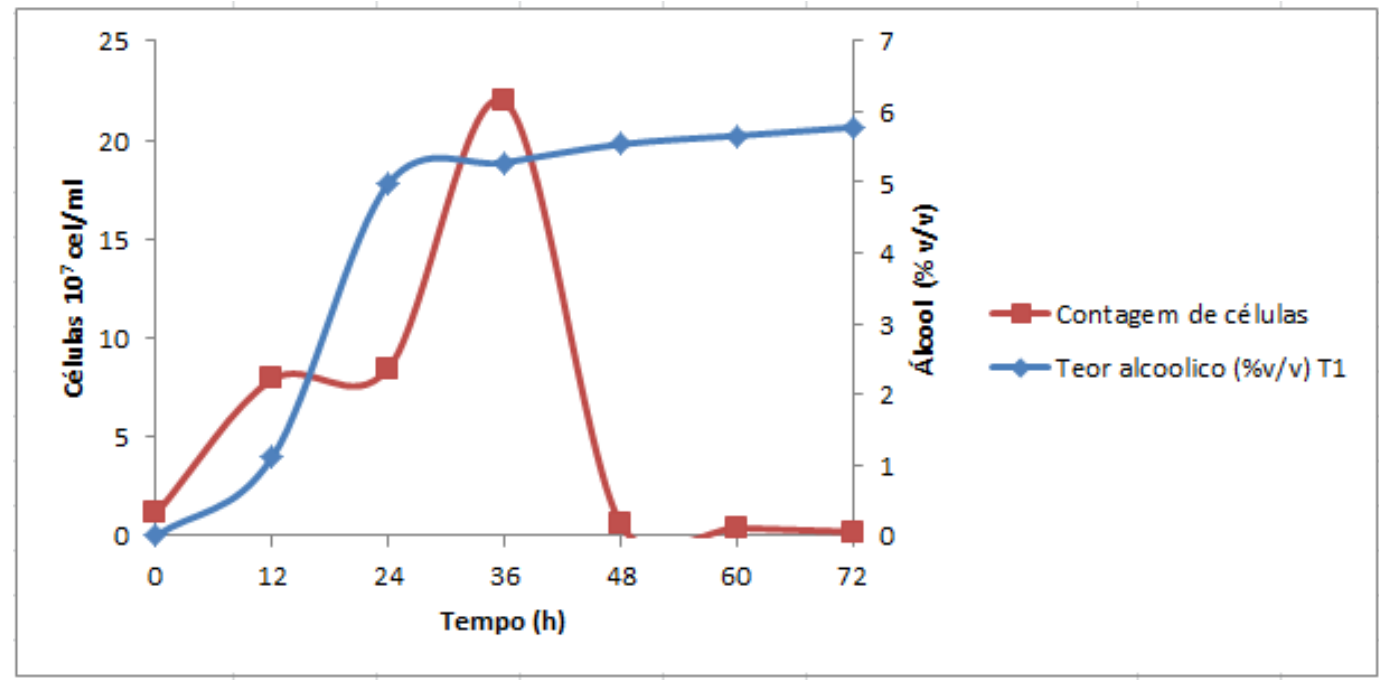

Figura B15. Crescimento celular em relação à produção de álcool durante a fermentação para a cerveja que recebeu o Tratamento 1 ( cerveja aromatizada com $0 \%$ de café).

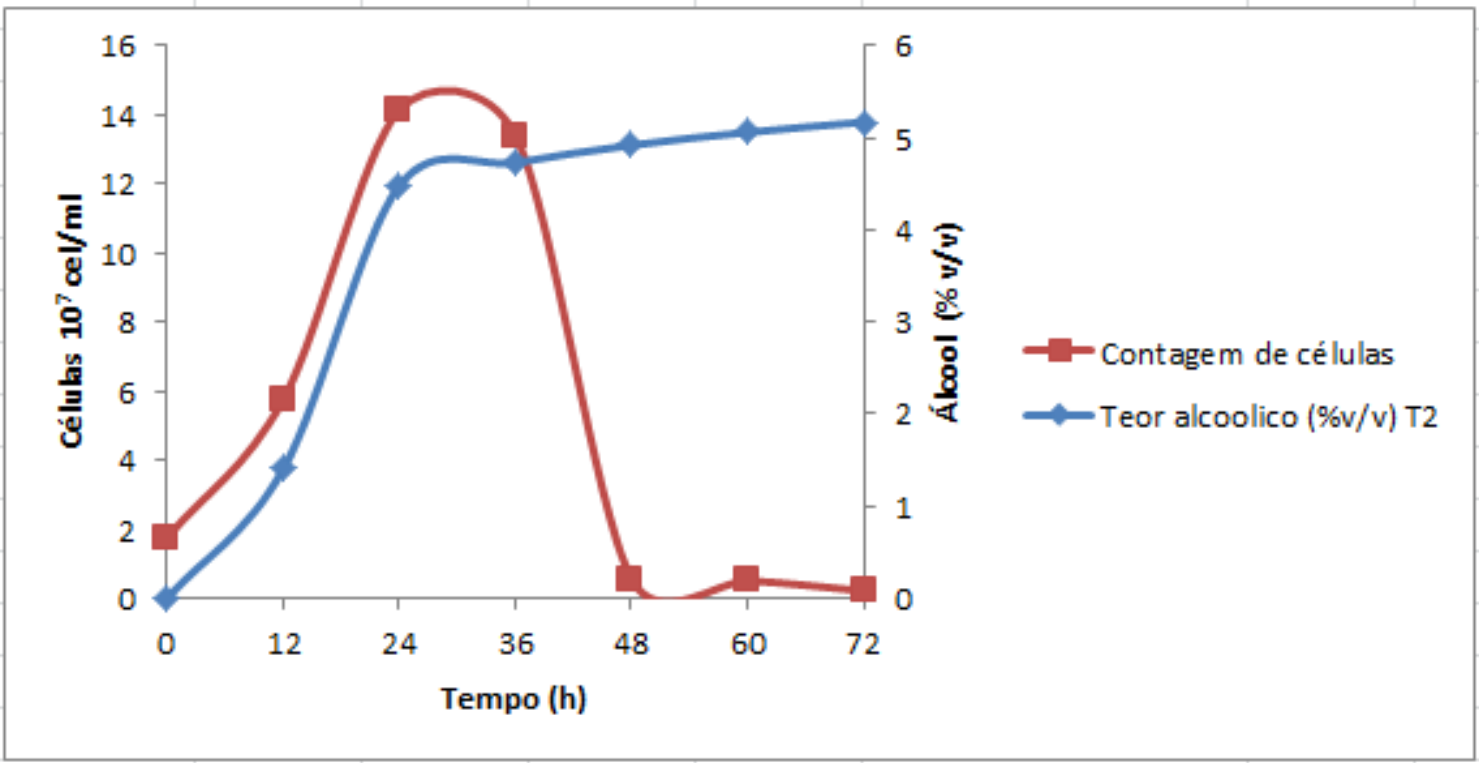

Figura B16. Crescimento celular em relação à produção de álcool durante a fermentação para a cerveja que recebeu o Tratamento 2 ( cerveja aromatizada com $15 \%$ de café). 


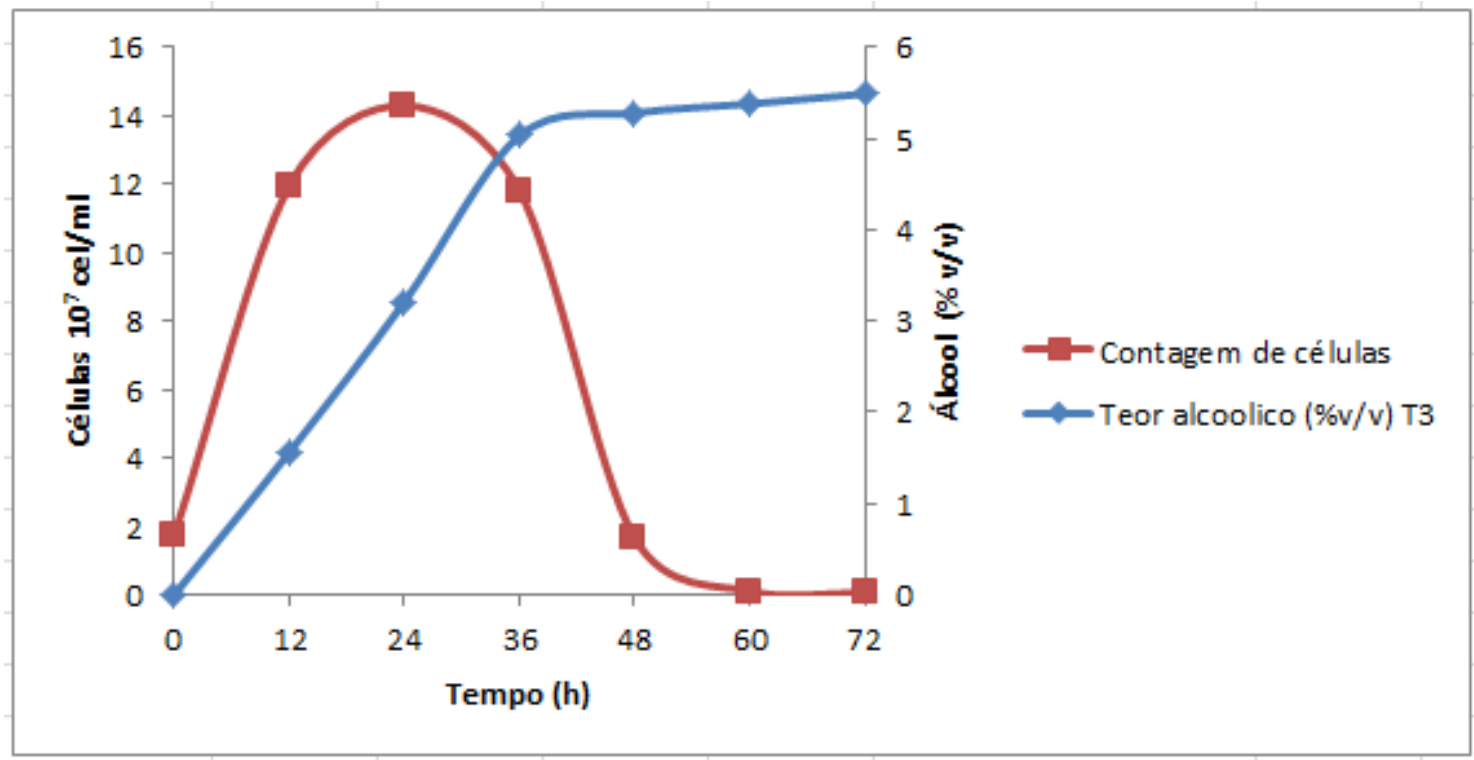

Figura B17. Crescimento celular em relação à produção de álcool durante a fermentação para a cerveja que recebeu o Tratamento 3 ( cerveja aromatizada com $25 \%$ de café).

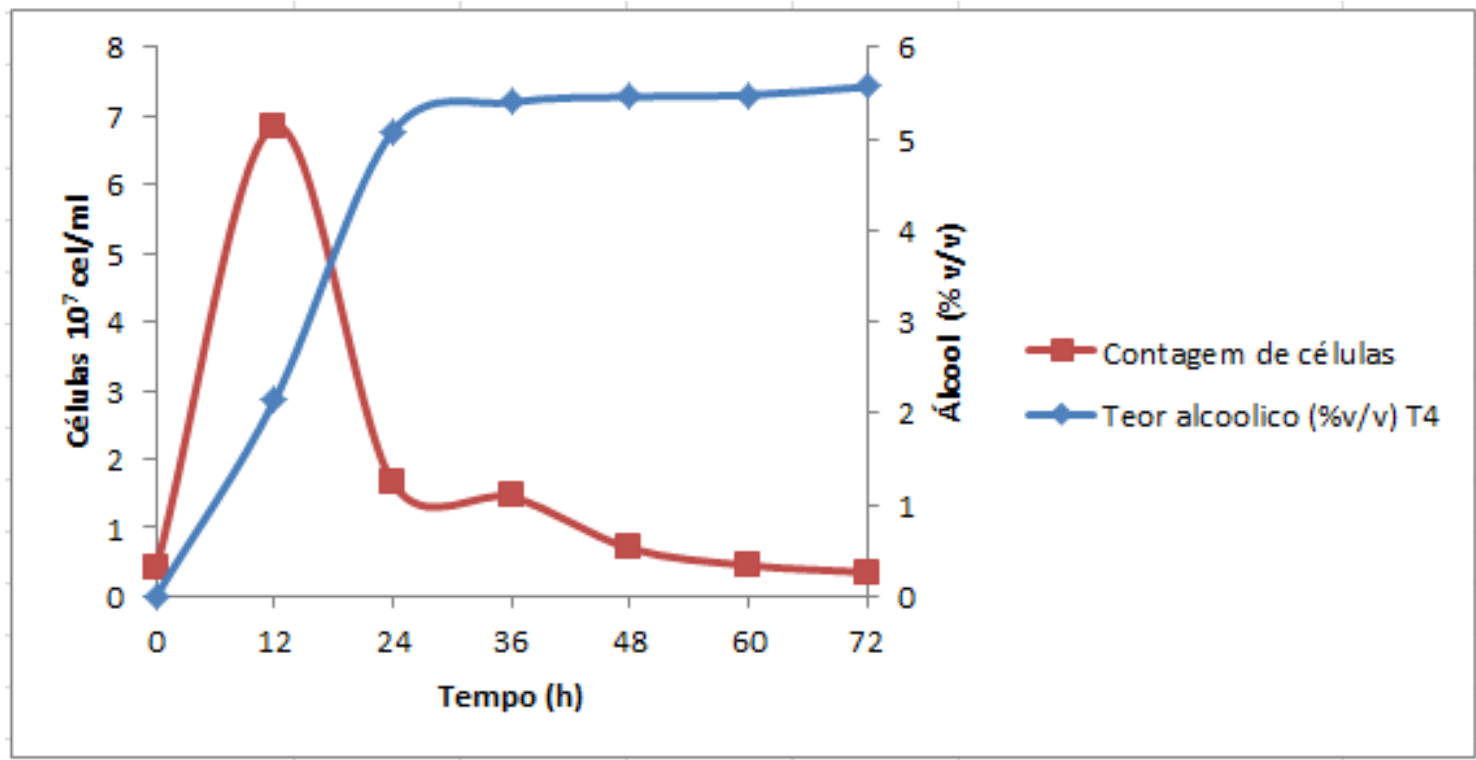

Figura B18. Crescimento celular em relação à produção de álcool durante a fermentação para a cerveja que recebeu o Tratamento 4 ( cerveja aromatizada com $35 \%$ de café). 


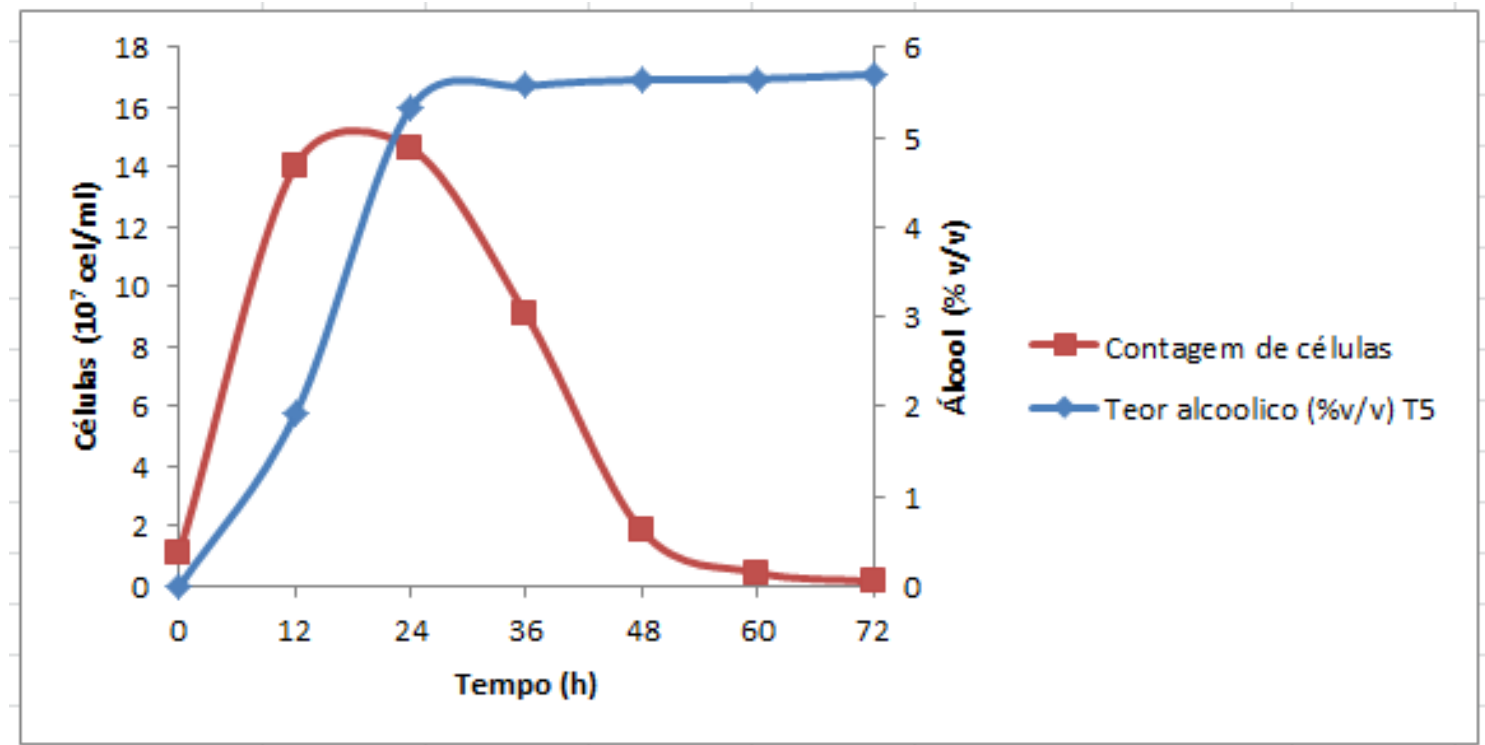

Figura B19. Crescimento celular em relação à produção de álcool durante a fermentação para a cerveja que recebeu o Tratamento 5 ( cerveja aromatizada com $45 \%$ de café).

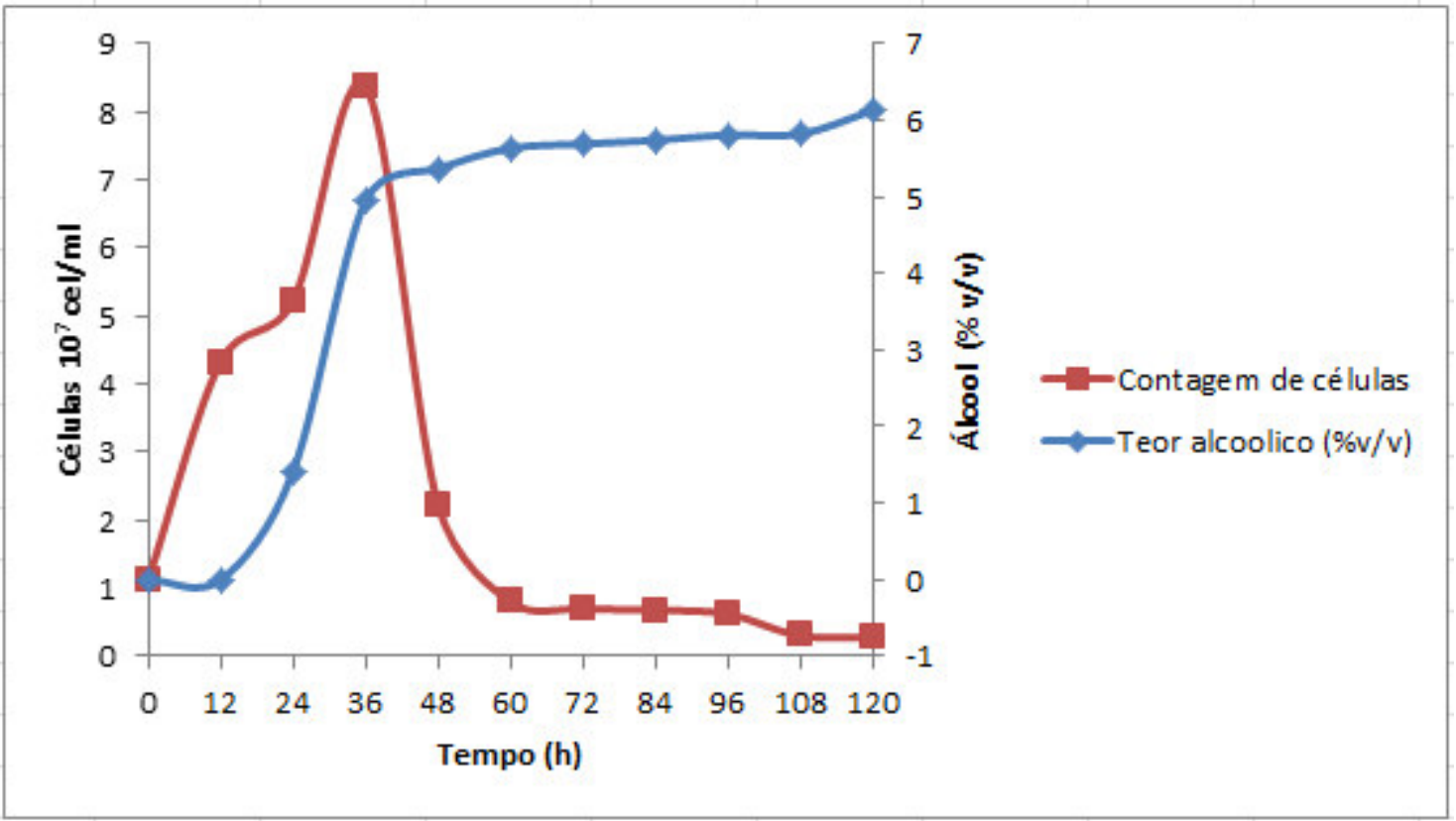

Figura B20. Crescimento celular em relação à produção de álcool durante a fermentação da cerveja produzida em escala piloto com $45 \%$ de café 